\title{
Infections: Viruses
}

\subsection{Clinical Signs and Symptoms}

Signs and symptoms of (Table 26.1):

- Meningitis

- Encephalitis

- Cerebral dysfunctions (delirium, lethargy, confusion, stupor, coma)

- Seizures

- Focal neurologic deficits

\subsection{Classification of Viruses}

Classification of viruses based on their nuclei acid into (Tables 26.2 and 26.3):

- DNA viruses

- RNA viruses

The diseases caused by viruses are listed in Table 26.4 while brain diseases caused by viruses are depicted in Tables 26.5 and 26.6.

\subsection{Epidemiology}

\section{Incidence}

- 1.5-7 cases/100,000 inhabitants/year, excluding epidemics

- True incidence of these infections is difficult to determine because

Table 26.1 Neurologic signs and syndromes related to affected regions

\begin{tabular}{|c|c|c|}
\hline Localization & Syndrome & Neurologic signs \\
\hline Meninges & - Meningitis & $\begin{array}{l}\text { - Headache } \\
\text { - Vomiting } \\
\text { - Photophobia } \\
\text { - Focal neurologic } \\
\text { deficits } \\
\text { - Alterations in } \\
\text { consciousness }\end{array}$ \\
\hline $\begin{array}{l}\text { Brain } \\
\text { parenchyma } \\
\text { diffuse }\end{array}$ & - Encephalitis & $\begin{array}{l}\text { - Alterations in } \\
\text { consciousness } \\
\text { - Seizures } \\
\text { - Multifocal neurologic } \\
\text { deficits }\end{array}$ \\
\hline $\begin{array}{l}\text { Brain } \\
\text { parenchyma } \\
\text { focal }\end{array}$ & $\begin{array}{l}\text { - Encephalitis } \\
\text { - Cerebritis }\end{array}$ & $\begin{array}{l}\text { - Focal neurologic } \\
\text { deficits } \\
\text { - Seizures }\end{array}$ \\
\hline $\begin{array}{l}\text { Brain stem } \\
\text { and posterior } \\
\text { cranial fossa }\end{array}$ & $\begin{array}{l}\text { - Brain stem } \\
\text { encephalitis } \\
\text { - Cerebellitis }\end{array}$ & $\begin{array}{l}\text { - Opto- and } \\
\text { pupillomotor } \\
\text { disturbances } \\
\text { - Nuclear cranial nerve } \\
\text { lesions } \\
\text { - Dysarthria } \\
\text { - Bilateral pyramidal } \\
\text { tract signs } \\
\text { - Alterations in } \\
\text { consciousness } \\
\text { - Breathing insufficiency } \\
\text { - Vegetative signs }\end{array}$ \\
\hline Spinal cord & - Myelitis & $\begin{array}{l}\text { - Paraplegia } \\
\text { - Brown Séquard } \\
\text { syndrome } \\
\end{array}$ \\
\hline Arteries & - Arteritis & $\begin{array}{l}\text { Sudden focal } \\
\text { neurologic deficit }\end{array}$ \\
\hline Veins & \begin{tabular}{|l|} 
- Septic \\
venous sinus \\
thrombosis
\end{tabular} & $\begin{array}{l}\text { - Headache } \\
\text { - Seizures } \\
\text { - Raised brain pressure } \\
\text { - Focal neurologic } \\
\text { deficits }\end{array}$ \\
\hline
\end{tabular}


Table 26.2 Subdivision of viruses

\begin{tabular}{|c|c|c|}
\hline \multirow[t]{2}{*}{$\begin{array}{l}\text { DNA } \\
\text { viruses }\end{array}$} & Enveloped & $\begin{array}{l}\text { - Pox } \\
\text { - Herpes } \\
\text { - Hepadna }\end{array}$ \\
\hline & $\begin{array}{l}\text { Naked } \\
\text { capsid }\end{array}$ & $\begin{array}{l}\text { - Polyoma, Papilloma, Adeno } \\
\text { - Parvo }\end{array}$ \\
\hline \multirow[t]{4}{*}{$\begin{array}{l}\text { RNA } \\
\text { viruses }\end{array}$} & $+\mathrm{RNA}$ & $\begin{array}{l}\text { - Naked capsid: Picorna, Calici } \\
\text { - Enveloped: Toga, Flavi, Corona }\end{array}$ \\
\hline & -RNA & $\begin{array}{l}\text { Enveloped: Rhabdo, Filo, } \\
\text { Orthomyxo, Paramyxo, Bunya, } \\
\text { Arena }\end{array}$ \\
\hline & \pm RNA & - Double capsid: Reo \\
\hline & $\begin{array}{l}\text { +RNA via } \\
\text { DNA }\end{array}$ & - Enveloped: Retro \\
\hline
\end{tabular}

- Many cases are unreported.

- The diagnosis may not be considered.

- A specific viral etiology is never confirmed.

\section{Age Incidence}

- all ages possible

- CMV: congenital, adulthood

- HIV: adulthood

\section{Sex Incidence}

- dependent on virus

- HIV: predominantly males

- CMV: equal distribution

Table 26.3 A detailed subdivision of viruses

\begin{tabular}{|c|c|c|c|}
\hline \multicolumn{2}{|c|}{ Viral genome } & \multirow{2}{*}{\begin{tabular}{|l} 
Family name of virus \\
Herpesviridae
\end{tabular}} & \multirow[b]{2}{*}{$\begin{array}{l}\text { Family members } \\
\text { - HSV-1 } \\
\text { - HSV-2 } \\
\text { - Varicella-zoster virus } \\
\text { - Cytomegalovirus } \\
\text { - Epstein-Barr virus } \\
\text { - Human herpesvirus } 6 \\
\text { - Human herpesvirus } 7 \\
\text { - Human herpesvirus } 8 \\
\text { - Herpes simiae }\end{array}$} \\
\hline DNA & Double-stranded & & \\
\hline & & Adenoviridae & - Adenovirus \\
\hline & & Papovaviridae & $\begin{array}{l}\text { - JC virus } \\
\text { - Simian virus } 40\end{array}$ \\
\hline & Single-stranded & Parvoviridae & - Parvovirus B19 \\
\hline \multirow[t]{12}{*}{ RNA } & Double-stranded & Reoviridae & $\begin{array}{l}\text { - Coltivirus } \\
\text { - Seadornavirus }\end{array}$ \\
\hline & \multirow[t]{3}{*}{ Single-stranded sense non-segmented } & Retroviridae & $\begin{array}{l}\text { - Deltaretrovirus } \\
\text { - Lentivirus }\end{array}$ \\
\hline & & Coronaviridae & - Coronavirus \\
\hline & & Togaviridae & - Alphavirus \\
\hline & & Flaviviridae & - Flavivirus \\
\hline & & Picornaviridae & - Enterovirus \\
\hline & \multirow[t]{2}{*}{ Single-stranded antisense segmented } & Bunyaviridae & $\begin{array}{l}\text { - Orthobunyavirus } \\
\text { - Phlebovirus }\end{array}$ \\
\hline & & Arenaviridae & - Arenavirus \\
\hline & \multirow[t]{4}{*}{ Single-stranded antisense non-segmented } & Orthomyxoviridae & - Influenza viruses \\
\hline & & Paramyxoviridae & $\begin{array}{l}\text { - Henipavirus } \\
\text { - Morbilivirus } \\
\text { - Rubulavirus }\end{array}$ \\
\hline & & Rhabdoviridae & $\begin{array}{l}\text { - Rabies } \\
\text { - Borna }\end{array}$ \\
\hline & & Filoviridae & - Ebola \\
\hline
\end{tabular}


Table 26.4 List of viruses and related diseases of viruses

\begin{tabular}{|c|c|c|c|}
\hline & Viral family & Virus & Disease \\
\hline \multirow[t]{13}{*}{ DNA } & Papillomavirus & & $\begin{array}{l}\text { - Warts } \\
\text { - Condylomas } \\
\text { - Cervical cancer }\end{array}$ \\
\hline & \multirow[t]{2}{*}{ Polyomaviridae } & BK virus & - Renal disease \\
\hline & & JC virus & - Progressive multifocal leukoencephalopathy \\
\hline & Adenoviridae & & $\begin{array}{l}\text { - Respiratory disease } \\
\text { - Meningoencephalitis }\end{array}$ \\
\hline & \multirow[t]{3}{*}{ Alphaherpesvirinae } & Herpesvirus 1 & - Encephalitis \\
\hline & & Herpesvirus 2 & - Encephalitis \\
\hline & & Varicella-zoster virus & - Encephalitis \\
\hline & Gammaherpesvirinae & Epstein-Barr virus & - Encephalitis \\
\hline & Betaherpesvirinae & Cytomegalovirus & - Encephalitis \\
\hline & Poxviruses & & - Smallpox \\
\hline & Parvoviruses & & - Erythema infectiosum \\
\hline & \multirow[t]{2}{*}{ Picornaviruses } & Enterovirus & $\begin{array}{l}\text { - Encephalitis } \\
\text { - Meningitis } \\
\text { - Poliovirus infections (polyomyelitis, paralytic polio) }\end{array}$ \\
\hline & & Hepatovirus & - Hepatitis \\
\hline \multirow[t]{15}{*}{ RNA } & \multirow[t]{4}{*}{ Picornaviridae } & Poliovirus & $\begin{array}{l}\text { - Poliomyelitis } \\
\text { - Postpolio syndrome }\end{array}$ \\
\hline & & Enteroviruses & \\
\hline & & Cardiovirus genus & \\
\hline & & Encephalomyocarditis virus & \\
\hline & \multirow[t]{4}{*}{ Arboviruses } & Togaviridae, alphavirus genus & $\begin{array}{l}\text { - Eastern equine encephalitis } \\
\text { - Western equine encephalitis } \\
\text { - Venezuelan equine encephalitis }\end{array}$ \\
\hline & & Flaviviridae & $\begin{array}{l}\text { - Japanese encephalitis } \\
\text { - St. Louis Encephalitis } \\
\text { - Russian spring-summer encephalitis } \\
\text { - Central European encephalitis } \\
\text { - Kyasanur forest disease } \\
\text { - Murray valley encephalitis } \\
\text { - Rocio }\end{array}$ \\
\hline & & Bunyaviridae & $\begin{array}{l}\text { - La Crosse encephalitis } \\
\text { - Snowshoe hare virus } \\
\text { - California encephalitis } \\
\text { - Jamestown canyon encephalitis }\end{array}$ \\
\hline & & Reoviridae & - Colorado tick fever \\
\hline & \multirow[t]{3}{*}{ Paramyxoviruses } & Measles virus & - Measles \\
\hline & & Parainfluenza virus & - Limited respiratory tract infection \\
\hline & & Mumps virus & - Mumps \\
\hline & Orthomyxoviruses & Influenza $A$ and $B$ viruses & - Influenza \\
\hline & Rhabdoviruses & Rhabdovirus & - Rabies \\
\hline & \multirow[t]{2}{*}{ Retroviruses } & Oncovirinae (HTLV) & - Tropical spastic paraparesis \\
\hline & & Lentivirinae (HIV) & - Acquired immune deficiency syndrome (AIDS) \\
\hline
\end{tabular}


Table 26.5 Viral infections of the brain and their causative viral agents

\begin{tabular}{|c|c|}
\hline Encephalitis & $\begin{array}{l}\text { - } \text { HSV-1 } \\
\text { - Toga, Flavi, Bunya } \\
\text { encephalitis viruses } \\
\text { - Picornaviruses } \\
\text { - Arboencephalitis virus } \\
\text { - Varicella-zoster virus } \\
\text { - Rabies virus } \\
\text { - Polioviruses } \\
\text { - Coxsackie A and B viruses }\end{array}$ \\
\hline Meningitis & $\begin{array}{l}\text { - HSV-2 } \\
\text { - Picornaviruses } \\
\text { - Mumps virus } \\
\text { - Enteroviruses } \\
- \text { Echoviruses } \\
- \text { Coxsackie virus } \\
\text { - Poliovirus } \\
\text { - Adenoviruses }\end{array}$ \\
\hline Paralysis & $\begin{array}{l}\text { - Poliovirus } \\
\text { - Enterovirus } 70 \text { and } 71 \\
\text { - Coxsackie A7 virus }\end{array}$ \\
\hline $\begin{array}{l}\text { Postinfectious } \\
\text { encephalitis (immune } \\
\text { mediated) }\end{array}$ & $\begin{array}{l}\text { - Measles virus } \\
\text { - Mumps virus } \\
\text { - Rubella virus } \\
\text { - Varicella-zoster virus } \\
\text { - Influenza virus }\end{array}$ \\
\hline Other & $\begin{array}{l}\text { - JC virus-progressive } \\
\text { multifocal } \\
\text { leukoencephalopathy (PML) } \\
\text { - Human Immunodeficiency } \\
\text { Virus (HIV) } \\
\text { - Human T-cell lymphotropic } \\
\text { virus } 1 \text { (HTLV-1) (tropical } \\
\text { spastic paraparesis) } \\
\text { - Measles variant (subacute } \\
\text { sclerosing panencephalitis) }\end{array}$ \\
\hline
\end{tabular}

\section{Localization}

- Brain, any region

- Temporal lobe for HSV

\subsection{Neuroimaging Findings}

\section{General Imaging Findings}

- Viral CNS infections can either lead to meningitis or (meningo-)encephalitis.

- Imaging of viral encephalitis often nonspecific-like focal or diffuse edema (acute infection) or focal atrophy (chronic infection)except HSV encephalitis showing an almost pathognomonic involvement of limbic system.

- Location depends on causative agent.
Table 26.6 Acute and chronic viral infection affecting the brain

\begin{tabular}{|c|c|}
\hline $\begin{array}{l}\text { Acute viral } \\
\text { infection }\end{array}$ & $\begin{array}{l}\text { - Aseptic meningitis } \\
\text { - Polyomyelitis } \\
\text { - Neonatal enteroviral encephalitis } \\
\text { - Herpesvirus infections } \\
\text { - Herpes simplex virus infection } \\
\text { - Atypical herpes simplex } \\
\text { encephalitis } \\
\text { - Chronic granulomatous herpes } \\
\quad \text { simplex encephalitis } \\
\text { - Necrotizing myelopathy } \\
\text { - Neonatal HSV encephalitis } \\
\text { - Varicella-zoster virus (ZVZ) } \\
\quad \text { infection } \\
\text { - Epstein-Barr virus (EBV) infection } \\
\text { - Cytomegalovirus (CMV) infection } \\
\text { - Human herpesviruses } 6 \text { and } 7 \\
\text { - Adenovirus } \\
\text { - Paramyxoviruses } \\
\text { - Mumps virus } \\
\text { - Measles } \\
\text { - Rubella encephalitis } \\
\text { - Rabies } \\
\text { - Arbovirus infections }\end{array}$ \\
\hline $\begin{array}{l}\text { Chromic and } \\
\text { subacute } \\
\text { viral } \\
\text { infections }\end{array}$ & $\begin{array}{l}\text { - Chronic enteroviral encephalomyelitis } \\
\text { - Subacute measles encephalitis } \\
\text { - Subacute sclerosing panencephalitis } \\
\text { (SSPE) } \\
\text { - Progressive rubella panencephalitis } \\
\text { - Progressive multifocal } \\
\text { leukoencephalopathy (PML) } \\
\text { - Human T-cell leukemia/lymphotropic } \\
\text { virus-1 (HTLV-1) } \\
\text { - Human immunodeficiency virus (HIV) } \\
\text { - Rasmussen encephalitis }\end{array}$ \\
\hline
\end{tabular}

\section{CT Non-Contrast-Enhanced}

- Meningitis: Normal

- Encephalitis: Hypodense edema, loss of graywhite matter differentiation, chronic infection may cause brain atrophy

\section{CT Contrast-Enhanced}

- Meningitis: Meningeal enhancement often missing

- Encephalitis: Enhancement possible

\section{MRI-T2}

- Encephalitis: Hyperintensity of involved brain areas 


\section{MRI-FLAIR}

- Encephalitis: Hyperintensity of involved brain areas

\section{MRI-T1}

- Encephalitis: Hypointense edema with loss of gray-white matter differentiation

\section{MRI-T1 Contrast-Enhanced}

- Meningitis: Weak meningeal enhancement

- Encephalitis: Variable enhancement

\section{MRI-T2*/SWI}

- Encephalitis: Hemorrhages (HSV, VZV, Japanese encephalitis)

\section{MR-Diffusion Imaging}

- Encephalitis: Diffusion restriction common

Typical MR imaging patterns of specific viral encephalitides are listed in Table 26.7.

\section{Nuclear Medicine Imaging Findings}

- In HIV-infected patients

- Reduced brain perfusion SPECT and reduced FDG-PET uptake of cortical structures (medial frontal, temporoparietal) are described.
- FDG shows diffuse hypermetabolism in subcortical and deep white matter, basal ganglia, and thalami in some cases.

- In herpes simplex encephalitis

- HMPAO showed increased uptake followed by a decrease in tracer uptake in the recovery phase and ECD decreased uptake of the affected temporal lobe (most likely due to disturbed membrane and intracellular metabolism).

- FDG-PET shows hippocampal hypermetabolism in the acute phase of herpes simplex encephalitis followed by hypometabolism after 3-9 months, but it is reported, that hypometabolism can persist for years.

- Studies with various imaging agents are performed to assess different pathologic steps in neuroinflammation.

\subsection{Neuropathology Findings}

\section{Macroscopic Features}

- No discernible lesion

- Hemorrhagic lesion

- Necrotic lesion

Table 26.7 Typical MR imaging patterns of specific viral encephalitides

\begin{tabular}{|c|c|}
\hline HSV & $\begin{array}{l}\text { - Limbic system and temporal lobe } \\
\text { - Often hemorrhages and enhancement }\end{array}$ \\
\hline CMV & $\begin{array}{l}\text { - Periventricular white matter, subependymal enhancement } \\
\text { - Calcifications in perinatal CMV }\end{array}$ \\
\hline EBV & $\begin{array}{l}\text { - Symmetric involvement of basal ganglia, thalami, cortex, or brain stem } \\
\text { - Rarely EBV-cerebellitis }\end{array}$ \\
\hline VZV & $\begin{array}{l}\text { - Multifocal cortical areas } \\
\text { - Hemorrhagic infarctions possible }\end{array}$ \\
\hline HIV & $\begin{array}{l}\text { - Brain atrophy } \\
\text { - Symmetric confluent white matter lesions (periventricular, basal ganglia, centrum semiovale, } \\
\text { brain stem, cerebellum), } \\
\text { - No enhancement }\end{array}$ \\
\hline Rabies virus & $\begin{array}{l}\text { - Diffuse involvement of basal ganglia, thalami, periventricular white matter, brain stem, and } \\
\text { hippocampi }\end{array}$ \\
\hline $\begin{array}{l}\text { TBEV (Tick-borne } \\
\text { encephalitis virus) }\end{array}$ & $\begin{array}{l}\text { - MRI and CT often normal } \\
\text { - Rarely lesions in thalamus, cerebellum, caudate nucleus, and brain stem }\end{array}$ \\
\hline JC Virus (PML) & $\begin{array}{l}\text { - Confluent subcortical white matter lesions, predominantly in parieto-occipital lobes } \\
\text { - U-fibers involved }\end{array}$ \\
\hline $\begin{array}{l}\text { JEV (Japanese } \\
\text { encephalitis virus) }\end{array}$ & - Bilateral symmetric lesions in thalami, basal ganglia, and midbrain \\
\hline Enteroviruses & - Posterior medulla oblongata and pons, dentate nuclei, and midbrain \\
\hline
\end{tabular}




\section{Microscopic Features}

- See specific subchapters

- Perivascular lymphocytic cuffing

- Gliomesenchymal nodules

- Multinucleated giant cells

- Large cells with inclusion bodies

- Reactive astrogliosis

- Leukoencephalopathies

\section{Immunohistochemical Staining} Characteristics

- Antibodies directed against a specific virus or part of the virus

- HIV: p24, gp41

\section{Differential Diagnosis}

- Necrosis of malignant tumors or metastases

- Necrosis from other infectious agents

\subsection{Molecular Neuropathology}

Properties of viruses, i.e., DNA versus RNA viruses (Table 26.8)

- Entry into the body

- Viral receptors (Table 26.9)

- Delivery of the virus to the target tissue

- Interaction of virus with target tissue

- Stability of virus in the body

- Ability to establish viremia

- Ability to spread through the reticuloendothelial system

- Cytopathogenesis

- Failed infection (abortive infection)

- Cell death (lytic infection)

- Replication without cell death (persistent infection)

- Presence of virus without production but with potential for reactivation (latentrecurrent infection)

- Host responses

- Antigen-nonspecific (innate) host defenses

- Antigen-specific immune responses

- Viral mechanisms of escape to immune responses

- Immunopathology

- Interferon

- T-cell responses: cell killing, inflammation
Table 26.8 Properties of DNA viruses and RNA viruses

\begin{tabular}{|c|c|}
\hline $\mathrm{DN} A$ & \\
\hline $\begin{array}{l}\text { DNA is not transient or } \\
\text { labile. } \\
\text { Many DAN viruses } \\
\text { establish persistent } \\
\text { infections. } \\
\text { DNA genomes reside in } \\
\text { the nucleus. } \\
\text { - Viral DNA resembles } \\
\text { host DNA for } \\
\text { transcription and } \\
\text { replication. } \\
\text { Viral genes must } \\
\text { interact with host } \\
\text { transcriptional } \\
\text { machinery. } \\
\text { Viral gene transcription } \\
\text { is temporally regulated. } \\
\text { Early genes encode } \\
\text { DNA-binding proteins } \\
\text { and enzymes. } \\
\text { Late genes encode } \\
\text { structural and other } \\
\text { proteins. } \\
\text { DNA polymerases } \\
\text { require a primer to } \\
\text { replicate the viral } \\
\text { genome. } \\
\text { The larger DNA viruses } \\
\text { encode means and } \\
\text { promote efficient } \\
\text { replication of their } \\
\text { genome. }\end{array}$ & $\begin{array}{l}\text { - RNA is labile and } \\
\text { transient. } \\
\text { - Most RNA viruses } \\
\text { replicate in the cytoplasm. } \\
\text { - Cells cannot replicate } \\
\text { RNA. RNA viruses must } \\
\text { encode an RNA- } \\
\text { dependent RNA } \\
\text { polymerase. } \\
\text { - The genome structure } \\
\text { determines the } \\
\text { mechanism of } \\
\text { transcription and } \\
\text { replication. } \\
\text { - RNA viruses are prone to } \\
\text { mutation. } \\
\text { The genome structure and } \\
\text { polarity determine how } \\
\text { viral messenger RNA is } \\
\text { generated and proteins are } \\
\text { processed. } \\
\text { RNA viruses, except (+) } \\
\text { RNA genome, must carry } \\
\text { polymerases } \\
\text { - All (-) RNA viruses are } \\
\text { enveloped. }\end{array}$ \\
\hline
\end{tabular}

Table 26.9 Viral receptors

\begin{tabular}{|c|c|c|}
\hline Virus & Target cell & Receptor \\
\hline Epstein-Barr virus & B-cell & $\begin{array}{l}\text { C3d complement } \\
\text { receptor CR2 } \\
(\mathrm{CD} 21)\end{array}$ \\
\hline $\begin{array}{l}\text { Human } \\
\text { immunodeficiency } \\
\text { virus }\end{array}$ & $\begin{array}{l}\text { Helper } \\
\text { T-cell }\end{array}$ & $\begin{array}{l}\text { CD4 molecule and } \\
\text { chemokine } \\
\text { co-receptor }\end{array}$ \\
\hline Rhinovirus & $\begin{array}{l}\text { Epithelial } \\
\text { cells }\end{array}$ & $\begin{array}{l}\text { ICAM-1 } \\
\text { (immunoglobulin } \\
\text { superfamily protein) }\end{array}$ \\
\hline Poliovirus & $\begin{array}{l}\text { Epithelial } \\
\text { cells }\end{array}$ & $\begin{array}{l}\text { Immunoglobulin } \\
\text { superfamily protein }\end{array}$ \\
\hline $\begin{array}{l}\text { Herpes simplex } \\
\text { virus }\end{array}$ & Many cells & $\begin{array}{l}\text { Herpesvirus entry } \\
\text { mediator (HVEM), } \\
\text { nectin } 1\end{array}$ \\
\hline Rabies virus & Neuron & $\begin{array}{l}\text { Acetylcholine } \\
\text { receptor, NCAM }\end{array}$ \\
\hline Influenza A virus & $\begin{array}{l}\text { Epithelial } \\
\text { cells }\end{array}$ & Sialic acid \\
\hline B19 parvovirus & $\begin{array}{l}\text { Erythroid } \\
\text { precursors }\end{array}$ & $\begin{array}{l}\text { Erythrocyte P } \\
\text { antigen (globoside) }\end{array}$ \\
\hline
\end{tabular}


- Antibody: complement, antibodydependent cellular cytotoxicity, immune complexes

- Other inflammatory responses

- Virus production in a tissue with release of the virus to other people (contagion)

- Transmission of viruses depends

- On source of the virus (tissue site of viral replication and secretion)

- Ability of the virus to endure hazards and barriers of the environment

\subsection{Treatment and Prognosis}

\section{Treatment}

Antiviral drugs aim at altering:

- Virion disruption

- Attachment

- Penetration and uncoating

- RNA synthesis

- Genome replication

- Protein synthesis

- Virion assembly and release

Antiviral drugs include:

- Nucleoside analogs

- Acyclovir

- Ganciclovir

- Nonnucleoside polymerase inhibitors

- Protease inhibitors

- Immunomudulators

\section{Biologic Behavior-Prognosis-Prognostic}

\section{Factors}

- Age of infection

- Congenital

- Nature of disease

- Target tissue

- Portal of entry of virus

- Access of virus to target tissue

- Tissue tropism of virus

- Permissiveness of cells for viral replication

- Pathogenic activity (strain)
- Severity of disease

- Cytopathic ability of virus

- Immune status

- Competence of the immune system

- Prior immunity to the virus

- Immunopathology

- Progression of viral disease

- Acquisition

- Activation of innate protections

- Incubation period

- Target tissue

- Host responses

- Contagion

- Resolution or persistent infection/chronic disease

\subsection{Unspecified Nodular Encephalitis}

The only histological finding in unspecified nodular encephalitis is the presence of gliomesenchymal nodules (GMN) (Fig. 26.1a-d). The finding is indicative of a viral infection.

GMN are:

- composed of microglia, macrophages, and reactive astrocytes

- found in the gray and white matter

- absence of multinucleated giant cells (MGC) or large cells containing inclusion bodies

The differential diagnosis for GMN includes

- HIV-1 encephalopathy/leukoencephalopathy

- Cytomegalovirus encephalitis

- The nodules are very suspicious to contain $\mathrm{CMV}$ when further serial sectioning is performed.

- Toxoplasma gondii encephalitis

Complete clarification and identification of an infectious agent is sometimes not possible. 

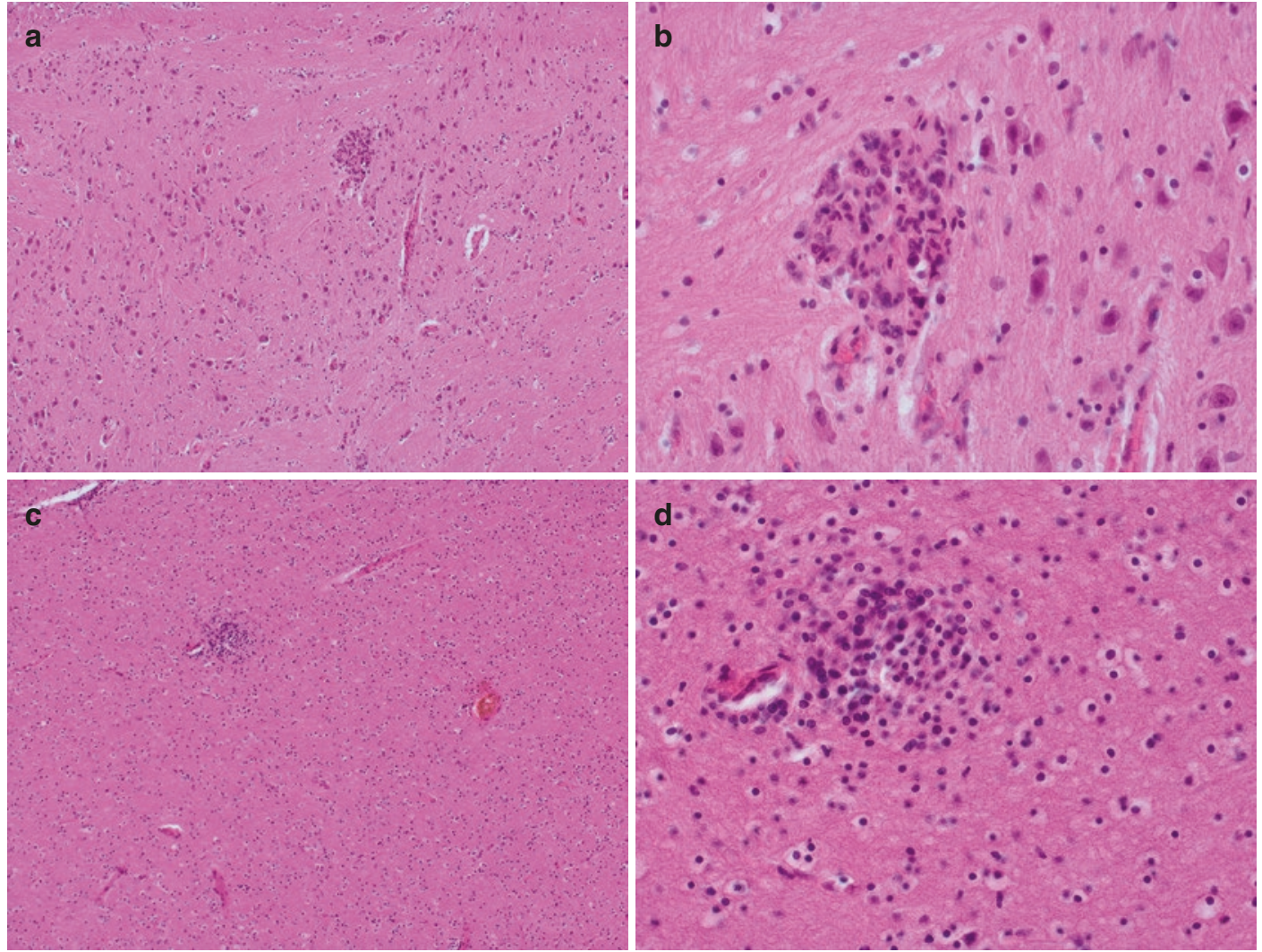

Fig. 26.1 Unspecified nodular encephalitis (a-d) (Stain: H\&E)

\subsection{RNA Viruses: Human Immunodeficiency Virus (HIV)-1}

Human immunodeficiency virus (HIV)-1 infection is a serious health problem worldwide as 33 million adults and 2 million children are infected with HIV-1. Despite preventive efforts, the epidemic continues to spread rapidly and the socioeconomic consequences of the neurologic dysfunction caused by HIV-1 infection are of enormous proportions. Most of the affected patients live in developing countries, where antiretroviral medications are not available.

HIV-viruses $(1,2)$ are

- Retroviruses, lentivirinae subfamily

- Roughly spheric, enveloped, RNA viruses
- Diameter of 80-120 nm

- RNA-dependent DNA polymerase

- Encode accessory genes

- Gag: group-specific antigen: core and capsid proteins

- Int: integrase

- Pol: polymerase: reverse transcriptase, protease, integrase

- Pro: protease

- Env: envelope: glycoproteins

- Tat: transactivation of viral and cellular genes

- Rev: regulation of RNA splicing and promotion of export to cytoplasm

- Nef: decreases cell surface CD4, facilitates T-cell activation, progression to AIDS

- Vif: virus infectivity, promotion of assembly, blocks a cellular antiviral protein 
- Vpu: facilitates virion assembly and release, induces degradation of $\mathrm{CD} 4$

- Vpr: transport of complementary DNA to nucleus, arresting of cell growth, replication in macrophages

- LTR: promoter, enhancer elements

Following involvement of the lung (75-85\%), the brain is the second most frequently affected organ (60-80\%) in HIV-1 infection.

Neurological signs and symptoms are seen:

- In about $50 \%$ of HIV-1-infected patients.

- In approximately $10 \%$ of the cases, they are the first presentation of the disease.

The term "AIDS dementia complex (ADC)" was coined in 1986 (Navia et al. 1986a, b) to describe impaired memory and concentration, psychomotor slowing and behavioral disturbances in $65 \%$ of patients, and has been attributed mainly to subcortical damage of AIDS brains (subcortical dementia). The name ADC was later changed into HIV-1-associated cognitive and motor complex with HIV-1-associated dementia complex (motor)/(behavior) (HAD) and HIV-1-associated myelopathy as its severe manifestations and HIV-1-associated minor cognitive/motor disorder as its mild manifestation (Force 1991).

Classification of HIV-associated neurocognitive disorders (HAND) (Antinori et al. 2007)

- Asymptomatic neurocognitive impairment (ANI)

- No evidence of pre-existing cause. Cognitive impairment must be attributable to HIV and no other etiology (e.g., dementia, delirium).

- The cognitive impairment does not interfere with activities of daily living.

- Involves at least two cognitive areas (memory, attention, language, processing speed, sensory perceptual, motor skills) documented by performance of $>1$ standard deviation below the mean of standardized neuropsychological testing.
- $30 \%$ prevalence in combination antiretroviral therapies (CART)-treated HIV+ individuals.

- Mild neurocognitive disorder (MND)

- No evidence of pre-existing cause. Cognitive impairment must be attributable to HIV and no.

- Other etiology (e.g., dementia, delirium).

- At least mild interference in $>1$ activities of daily living including mental acuity, inefficiency at work, homemaking or social functioning.

- 20-30\% prevalence in combination antiretroviral therapies (CART)-treated HIV+ individuals.

- HIV-associated dementia (HAD)

- No evidence of another pre-existing cause for dementia (i.e., CNS infections, CNS neoplasm, cerebrovascular disease).

- Marked interference in activities of daily living.

- Marked cognitive impairment involving at least two cognitive domains by performance of $>2$ standard deviation below the mean of standardized neuropsychological tests, especially in learning of new information, slowed information processing and defective attention or concentration.

- $2-8 \%$ prevalence in combination antiretroviral therapies (CART)-treated HIV+ individuals.

Despite the introduction of antiretroviral therapies with a greater life expectancy of HIV-1infected individuals, epidemiologic data suggest that involvement of the brain in AIDS patients continues to be a frequent autopsy finding.

Neuropathological examinations show in up to $95 \%$ of the brains changes that may be due to:

- primary effect of HIV-1

- probable effect of HIV-1

- opportunistic agents

- neoplasias

The neuropathological changes seen in the brains (Table 26.10) and peripheral nerve and skeletal muscle (Table 26.11) of HIV-1-infected patients are manifold. 
Table 26.10 The neuropathological changes seen in the brains of HIV-1-infected patients

\begin{tabular}{|c|c|}
\hline $\begin{array}{l}\text { Changes } \\
\text { primarily due to } \\
\text { HIV-1 }\end{array}$ & $\begin{array}{ll}\text { - } & \text { HIV-1 encephalitis (HIVE) } \\
\text { - } & \text { HIV-1 leukoencephalopathy } \\
& \text { (HIVL) } \\
\text { - } & \text { HIV-1 myelitis } \\
\text { - } & \text { Lymphocytic meningitis (LM) } \\
\text { - } & \text { Meningeal lymphocytic } \\
& \text { infiltration (MLI) } \\
\text { - } & \text { Perivascular lymphocytic } \\
& \text { infiltration (PLI) }\end{array}$ \\
\hline $\begin{array}{l}\text { Changes } \\
\text { probably due to } \\
\text { HIV-1 }\end{array}$ & $\begin{array}{l}\text { - Vacuolar myelopathy } \\
\text { - Vacuolar leukoencephalopathy }\end{array}$ \\
\hline $\begin{array}{l}\text { Opportunistic } \\
\text { infections- } \\
\text { viruses }\end{array}$ & $\begin{array}{ll}\text { - } & \text { Cytomegalovirus infection } \\
& (\mathrm{CMV}) \\
\text { - } & \text { Progressive multifocal } \\
& \text { leukoencephalopathy (PML) } \\
\text { - } & \text { Herpes simplex virus } 1 \\
\text { - } & \text { Herpes simplex virus } 2 \\
\text { - } & \text { Herpes zoster } \\
\text { - } & \text { HTLV-1 } \\
\text { - } & \text { Varicella-zoster virus }\end{array}$ \\
\hline $\begin{array}{l}\text { Opportunistic } \\
\text { infections- } \\
\text { parasites }\end{array}$ & $\begin{array}{l}\text { - Toxoplasma gondii } \\
\text { - Acanthamoeba } \\
\text { - Leptomyxid amoeba } \\
\text { - Trypanosoma cruzi } \\
\text { - Strongyloides }\end{array}$ \\
\hline $\begin{array}{l}\text { Opportunistic } \\
\text { infections- } \\
\text { fungi }\end{array}$ & $\begin{array}{l}\text { - } \quad \text { Aspergillus fumigatus } \\
\text { - Crydida albicans } \\
\text { neoformans } \\
\text { - Others including: Histoplasma, } \\
\text { Phycomyces, Coccidioides, } \\
\text { Blastomyces, Acremonium, } \\
\text { Cladosporium }\end{array}$ \\
\hline $\begin{array}{l}\text { Opportunistic } \\
\text { infections- } \\
\text { bacteria }\end{array}$ & $\begin{array}{l}\text { Pyogenic: Escherichia coli, } \\
\text { Listeria, Staphylococcus, } \\
\text { Salmonella } \\
\text { - Mycobacterial: Mycobacterium } \\
\text { tuberculosis, Mycobacterium } \\
\text { avium intracellulare } \\
\text { - Spirochetal: Treponema } \\
\text { pallidum } \\
\text { - Filamentous: Nocardia } \\
\text { - Miscellaneous: Whipple's } \\
\text { disease }\end{array}$ \\
\hline Neoplasias & $\begin{array}{l}\text { - Lymphoma (primary and } \\
\text { secondary) } \\
\text { - Kaposi sarcoma }\end{array}$ \\
\hline
\end{tabular}

\subsubsection{HIV-1 Encephalitis (HIVE)}

Since HIV-1 is rarely the cause of focal macroscopic lesions even in severely infected patients, systematic sampling of specimens for histological
Table 26.11 The changes occurring in the peripheral nervous system and in skeletal muscles of HIV-1-infected patients

\begin{tabular}{|c|c|}
\hline $\begin{array}{l}\text { Peripheral } \\
\text { nervous system }\end{array}$ & $\begin{array}{ll}\text { - } & \text { Acute inflammatory } \\
\text { demyelinating (poly) (radiculo) } \\
\text { neuropathy } \\
\text { - } \text { Chronic inflammatory } \\
\text { demyelinating (poly) (radiculo) } \\
\text { neuropathy } \\
\text { - Axonal neuropathy } \\
\text { - Ganglionitis, ganglioradiculitis, } \\
\text { (poly) (radiculo) neuritis } \\
\text { necrotizing vasculitis, vasculitic } \\
\text { neuropathy }\end{array}$ \\
\hline Skeletal muscle & $\begin{array}{l}\text { - } \text { (Poly) myositis } \\
\text { - Necrotizing myopathy } \\
\text { - Nemaline rod myopathy } \\
\text { - Vesicular myopathy, } \\
\text { mitochondrial myopathy } \\
\text { - Necrotizing vasculitis }\end{array}$ \\
\hline
\end{tabular}

examination is required. If focal lesions are present, they are almost always due to opportunistic infections, cerebrovascular complications, or neoplasms.

\subsubsection{Neuroimaging Findings}

\section{General Imaging Features}

- Brain atrophy and symmetric confluent white matter lesions (periventricular, basal ganglia, centrum semiovale, brain stem, cerebellum), no enhancement

\section{CT Non-Contrast-Enhanced}

- Brain atrophy

- Symmetric confluent white matter hypodensities

\section{CT Contrast-Enhanced}

- No enhancement

MRI-T2/FLAIR (Fig. 26.2a-d)

- Focal white matter hyperintensities

- Diffuse white matter hyperintensities

MRI-T1 (Fig. 26.2e, f)

- Lesions usually not seen

MRI-T1 Contrast-Enhanced (Fig. 26.2g, h)

- No enhancement 
MRI-DWI (Fig. 26.2i, j)

- No restricted diffusion.

\subsubsection{Microscopical Findings}

HIV-1 encephalitis is characterized by (Fig. 26.3a-j)

- Multiple disseminated foci composed of microglia, macrophages, and multinucleated giant cells (MGCs). The foci are predominantly located in the cortex, deep gray matter, and the white matter.

- The multinucleated giant cells (MGC) are the hallmark for HIV-1 encephalitis.

- They contain up to 20 round or elongated and basophilic nuclei which are usually arranged at the periphery of the cell.

- The cytoplasm is eosinophilic and appears densely stained in the center and vacuolated at the periphery.

- The cells are of monocyte/histiocyte lineage which includes microglia and macrophages.

- They are derived from HIV-1-mediated fusion of infected microglia and macrophages.

- The nucleic acids of HIV proteins have been demonstrated to be located in their cytoplasm.

- In their absence, the presence of HIV-antigen or HIV nucleic acids has to be demonstrated either by immunohistochemistry, i.e., gp41 and p24 (Fig. 26.3j) or by in situ hybridization.

- HIVE usually occurs in the later stages of the AIDS infection.

- The electron microscopical analysis revealed retroviral particles either free in the cytoplasm or in cytoplasmic cisternae.

- Microglia/macrophages and MGC are capable of HIV synthesis and, thus, constitute the major reservoir and vehicle for the spread of the virus.

- Synonyms previously used: giant cell encephalitis, multifocal giant cell encephalitis, multinucleated cell encephalitis, subacute encephalitis
There is no strong correlation between HIVE and the clinical stages of the HAD.

Despite the introduction of HAART with a greater life expectancy of infected individuals, epidemiologic data suggest that the prevalence of HIVE is on the rise.

\subsubsection{HIV-1 Leukoencephalopathy (HIVL)}

HIV-1 leukoencephalopathy is chararcterized by (Fig. 26.4a-j)

- diffuse damage to the white matter including

- myelin loss

- reactive astrogliosis

- macrophages

- multinucleated giant cells

- Myelin pallor is usually found around the gliomesenchymal nodule containing the MGC.

- Little or no inflammatory infiltrates are seen.

- In the absence of multinucleated giant cells, the presence of HIV-antigen or HIV nucleic acids has to be demonstrated either by immunohistochemistry or by in situ hybridization.

- Axonal damage can be demonstrated with immunohistochemistry for $\beta$-amyloid precursor protein.

- HIVL usually occur in the later stages of the AIDS infection.

- Synonyms previously used: progressive diffuse leukoencephalopathy

\subsubsection{Lymphocytic Meningitis (LM) and Perivascular Lymphocytic Infiltration (PLI)}

Lymphocytic meningitis (LM) is characterized by (Fig. 26.5a-f)

- Significant lymphocytic infiltrates in the leptomeninges.

- No opportunistic pathogens are encountered in the meninges. 

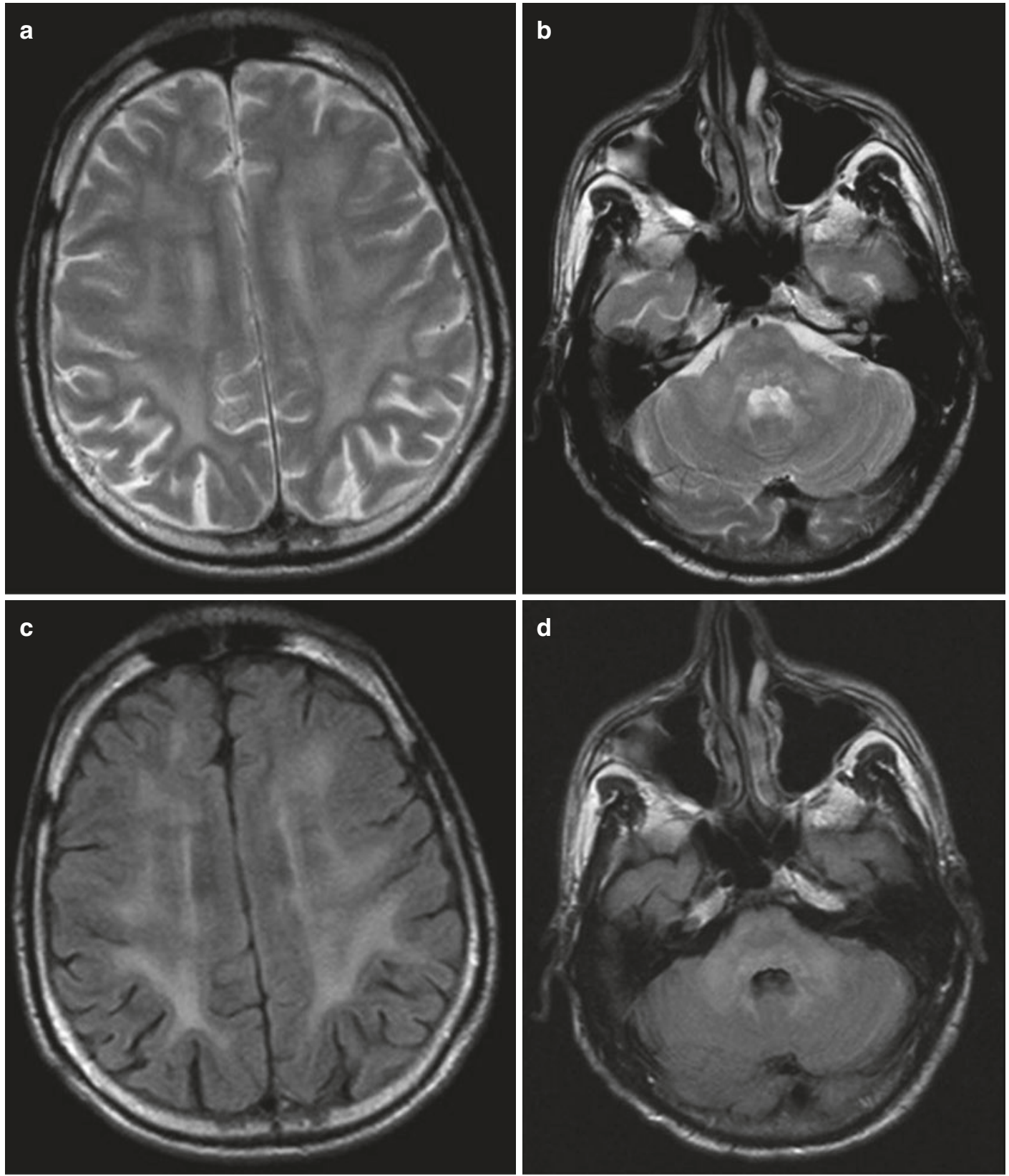

Fig. 26.2 HIV encephalopathy, T2 (a, b), FLAIR (c, d), T1 (e, f), T1 contrast $(\mathbf{g}, \mathbf{h})$, DWI $(\mathbf{i}, \mathbf{j})$ 

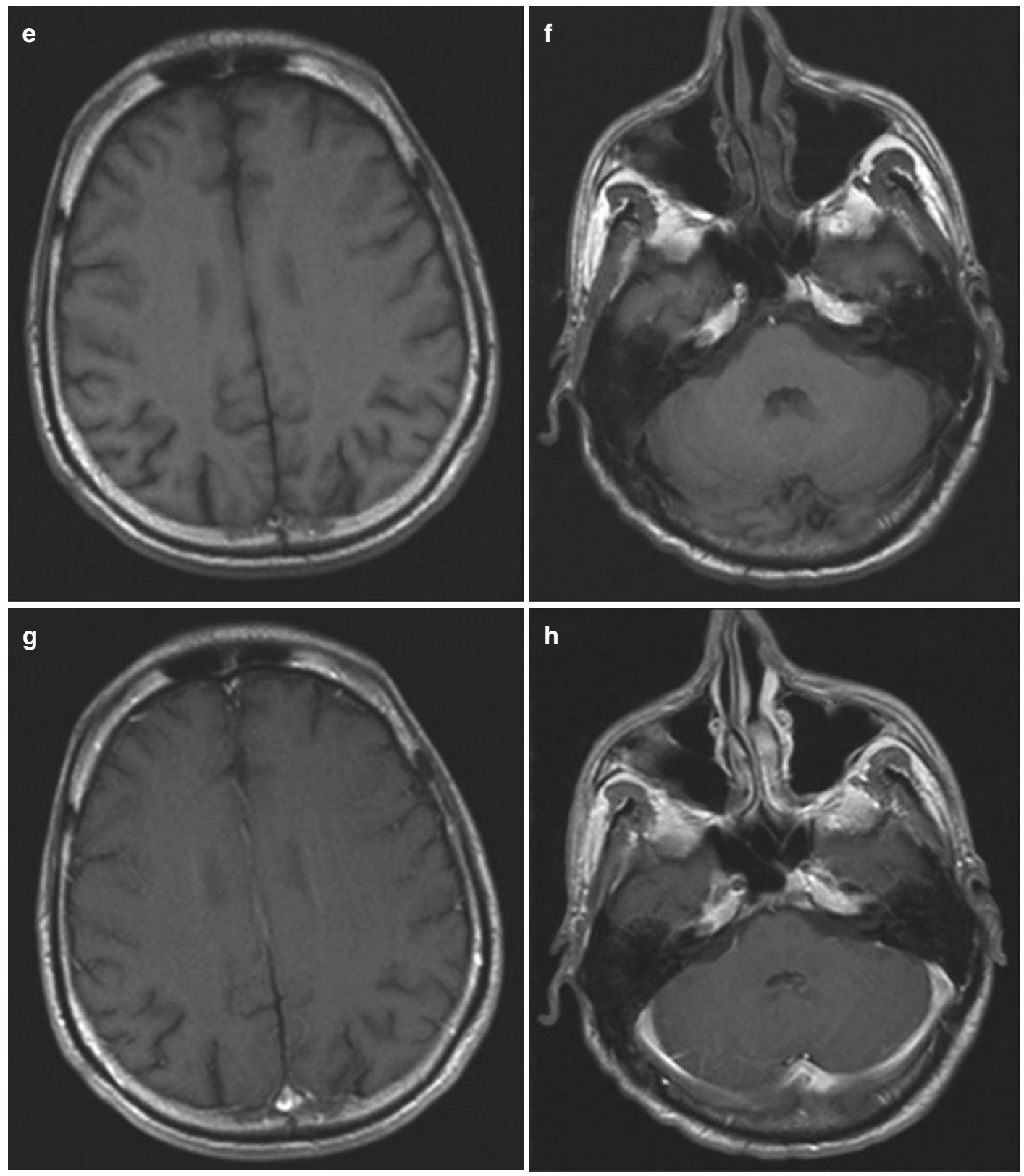

Fig. 26.2 (continued) 

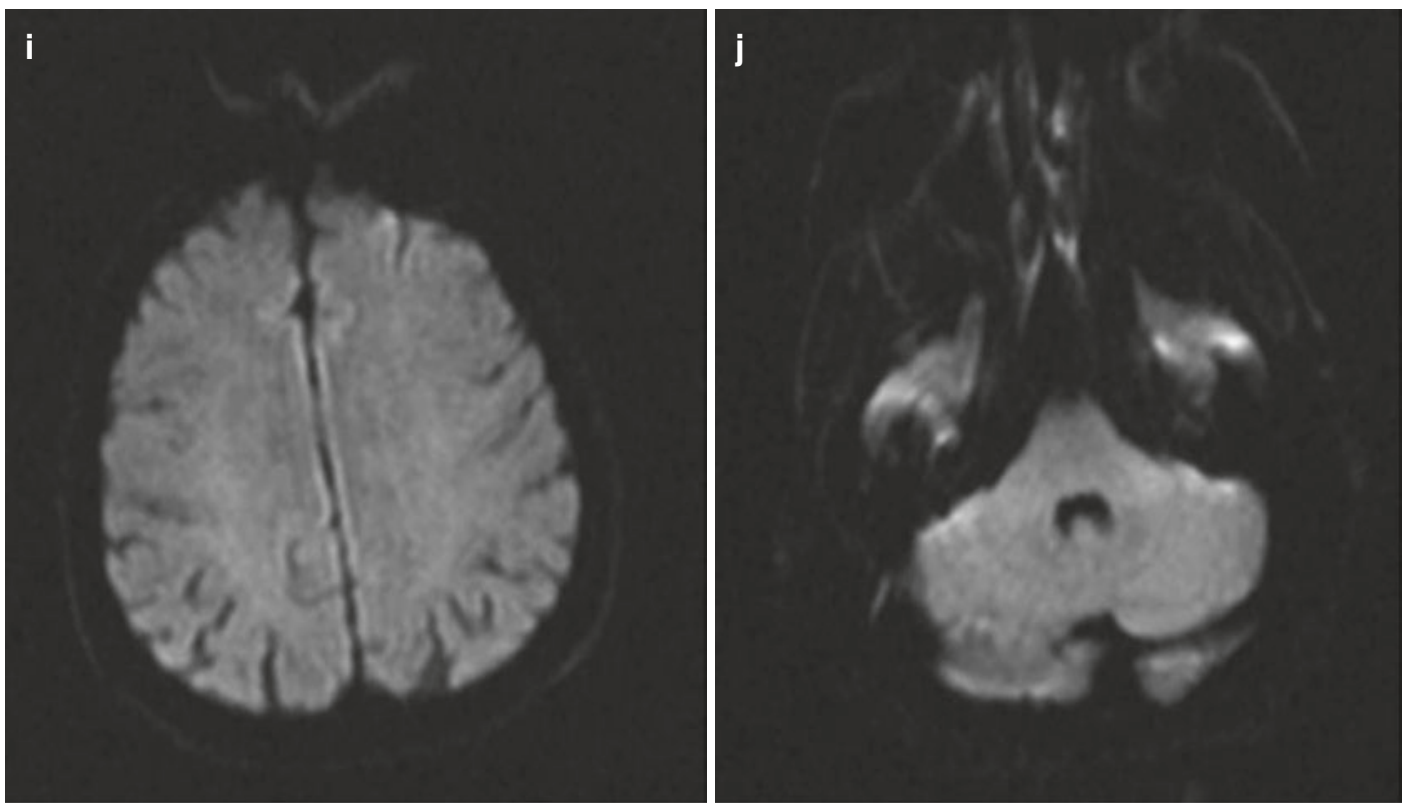

Fig. 26.2 (continued)

Perivascular lymphocytic infiltration $(P L I)$ is characterized by (Fig. 26.5g-j)

- Significant lymphocytic infiltrates in the perivascular spaces of the brain tissue.

- No opportunistic pathogens are encountered in the perivascular brain tissue.

It seems that lymphocytic infiltrates in the leptomeninges and in the perivascular spaces of the brain tissue constitute changes occurring in the early stages of the HIV-1 infection.

\subsubsection{Vacuolar Myelopathy (VM) and Vacuolar Leukoencephalopathy (VL)}

Vacuolar myelopathy is characterized by (Fig. 26.6a-f)

- Numerous vacuolar myelin swellings.

- Macrophages in multiple areas of the spinal cord.

- Predominant involvement of the dorsolateral spinal tracts.
- Some macrophages may be found in the vacuoles.

- Might not be specific for HIV-1 since they can occur in the absence of HIV.

- The axon is at first unaffected, but it is damaged in the later stages of the disease.

- VM might not be specific for HIV-1

Vacuolar leukoencephalopathy is characterized by

- Numerous vacuolar myelin swellings in the central white matter.

- Some macrophages may be found in the vacuoles.

- VL is a rare condition.

\subsubsection{Neuropathological Changes in Early Stages of HIV-1 Infection}

Brain changes in HIV-1 seropositive, non-AIDS cases include:

- Cerebral vasculitis was significantly more frequent and marked in HIV seropositive cases and was often associated with lymphocytic 

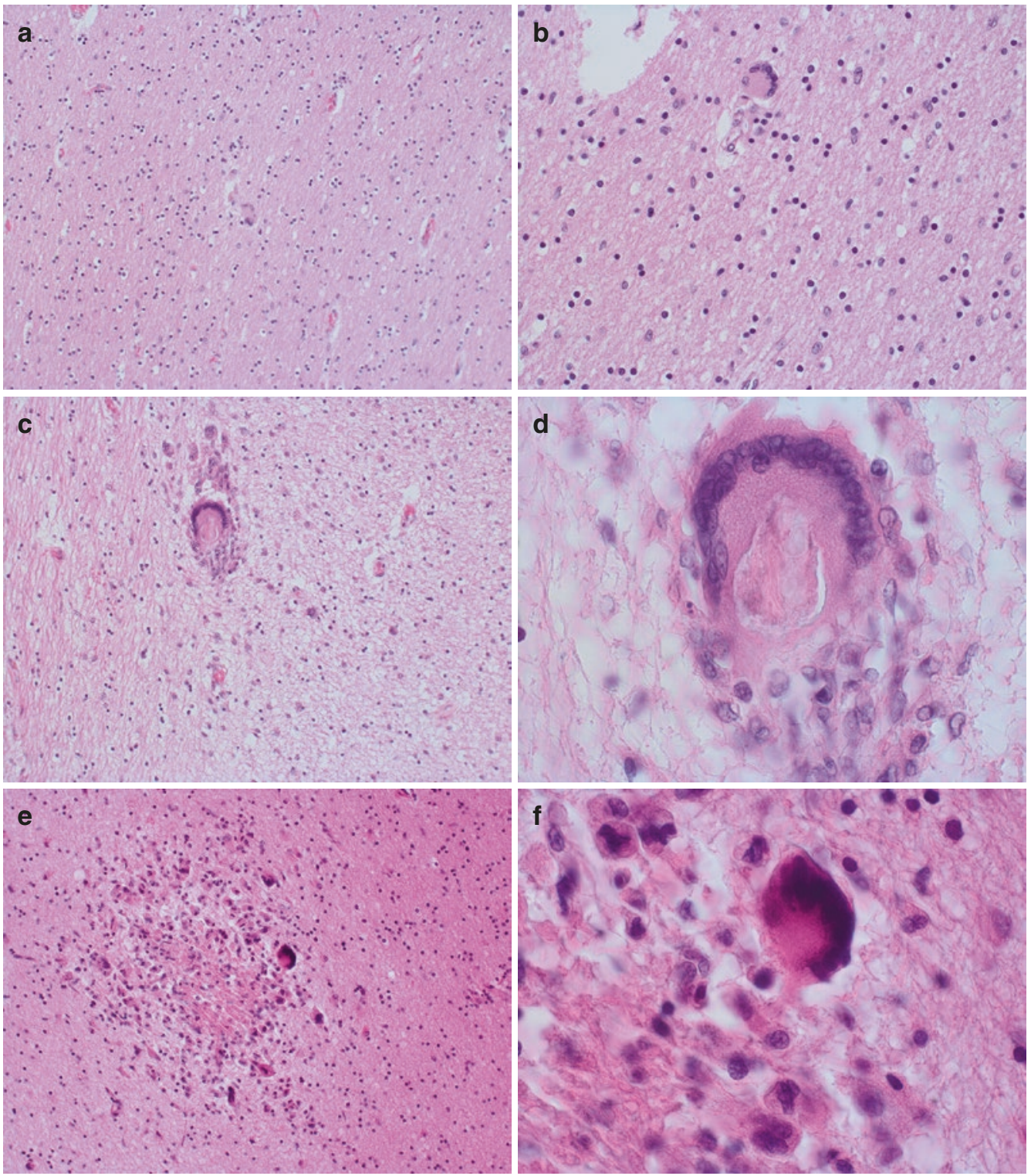

Fig. 26.3 HIV-1-encephalitis: multinucleated giant cells (a-i) (a-h: Stain: H\&E; i: Stain: cresyl violet). HIV-1 antigen shown in a small gliomesenchymal nodule (j: stain: immunohistochemistry for p24) 

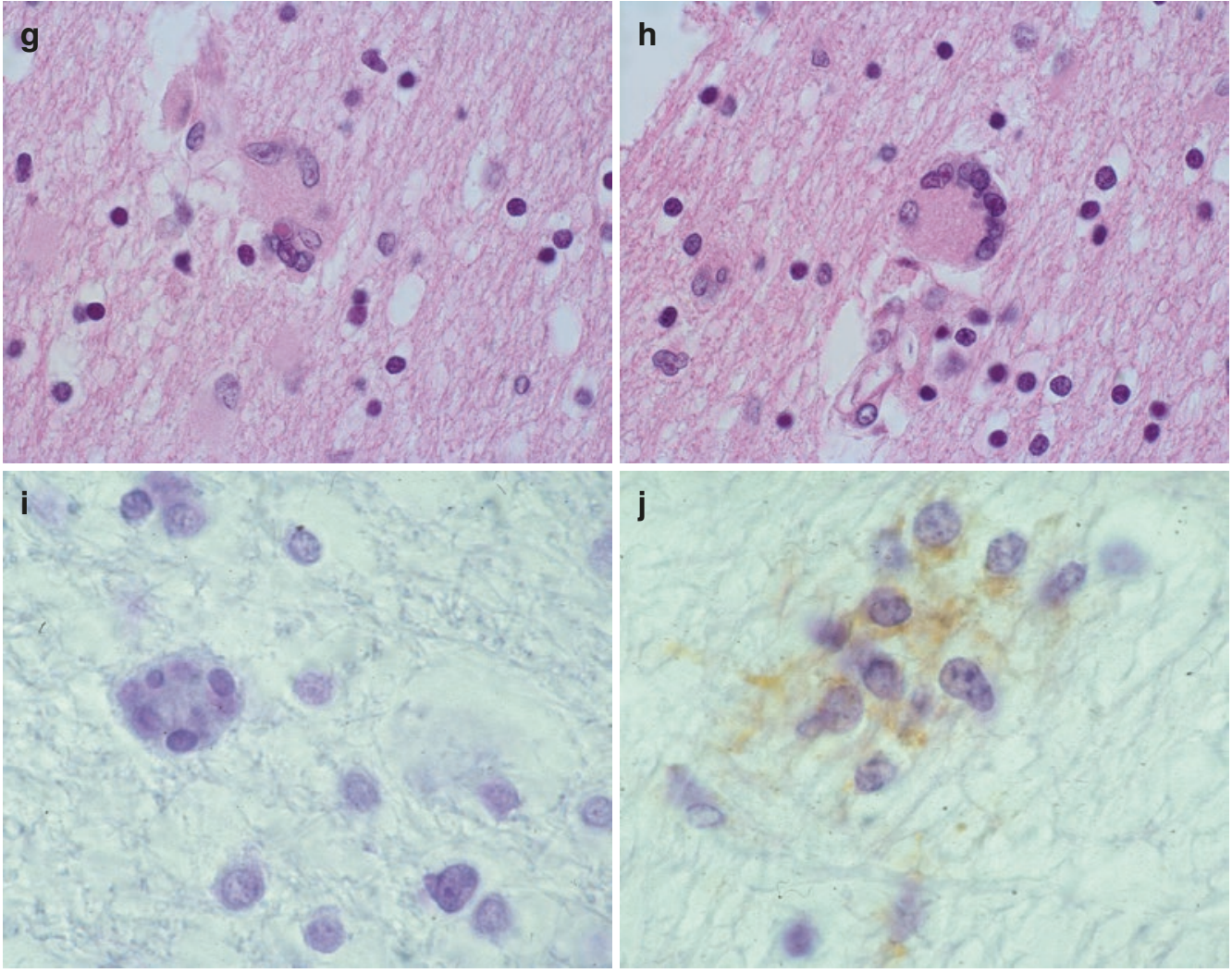

Fig. 26.3 (continued)

meningitis (Gray et al. 1992).

- Granular ependymitis, myelin pallor with reactive astrocytosis, and microglial proliferation were also more frequent and more severe in HIV seropositive cases. Immunohistochemistry was negative for HIV-antigens. Highly expressed cytokines (tumor necrosis factor- $\alpha$, interleukin (IL)-1,4,6) (Gray et al. 1992).

- Perivascular lymphocytic infiltrates (PLI) as well as lymphocytic infiltrates in the meninges (MLI) were found in $62.8 \%$ of the cases. PLI alone was seen in $61 \%$ of the cases, MLI alone in $43 \%$ of the cases, and the combination of PLI and MLI in 34\% of the cases (Weis et al., unpublished data).

\subsubsection{Neuropathological Changes in HIV-1-Infected Children}

Children born to HIV-1-infected mothers are in $10-40 \%$ of the cases also infected by the virus (Kozlowski et al. 1993). These children develop symptoms before the age of 2 years.

- About 30\% of the HIV-1 children develop opportunistic infection or HIV-1 encephalopathy within the first year of life.

- Brain growth is impaired leading to intellectual deficiency.

- The gross-anatomical analysis shows brains which are too small for the age.

- Sometimes atrophic gyri may be noted. 

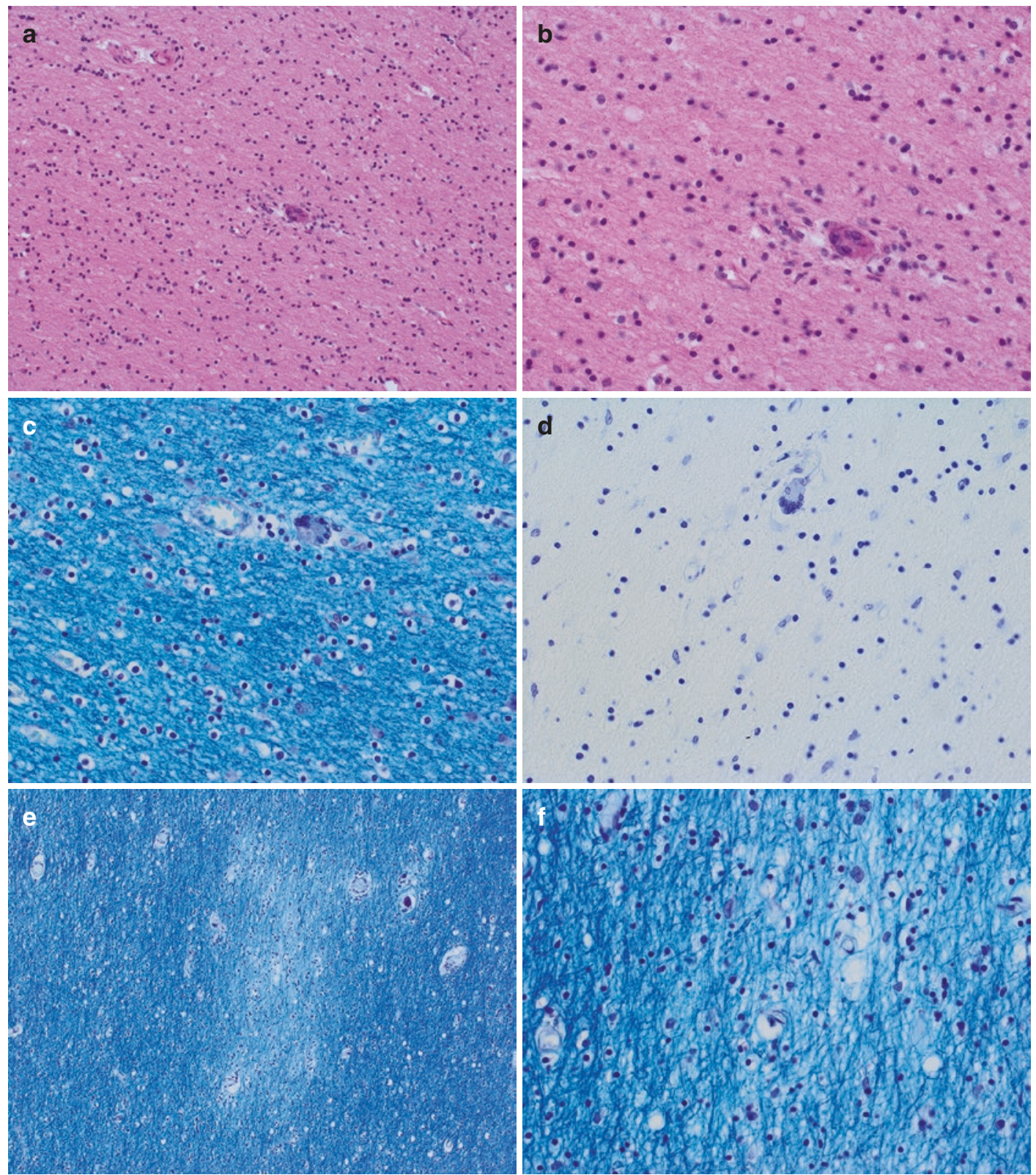

Fig. 26.4 HIV-leukoencephalopathy: presence of multinucleated giant cells in the white matter (a, b: H\&E, c: LFB, d: cresyl violet) and myelin pallor loss $(\mathbf{e}-\mathbf{j})$ 

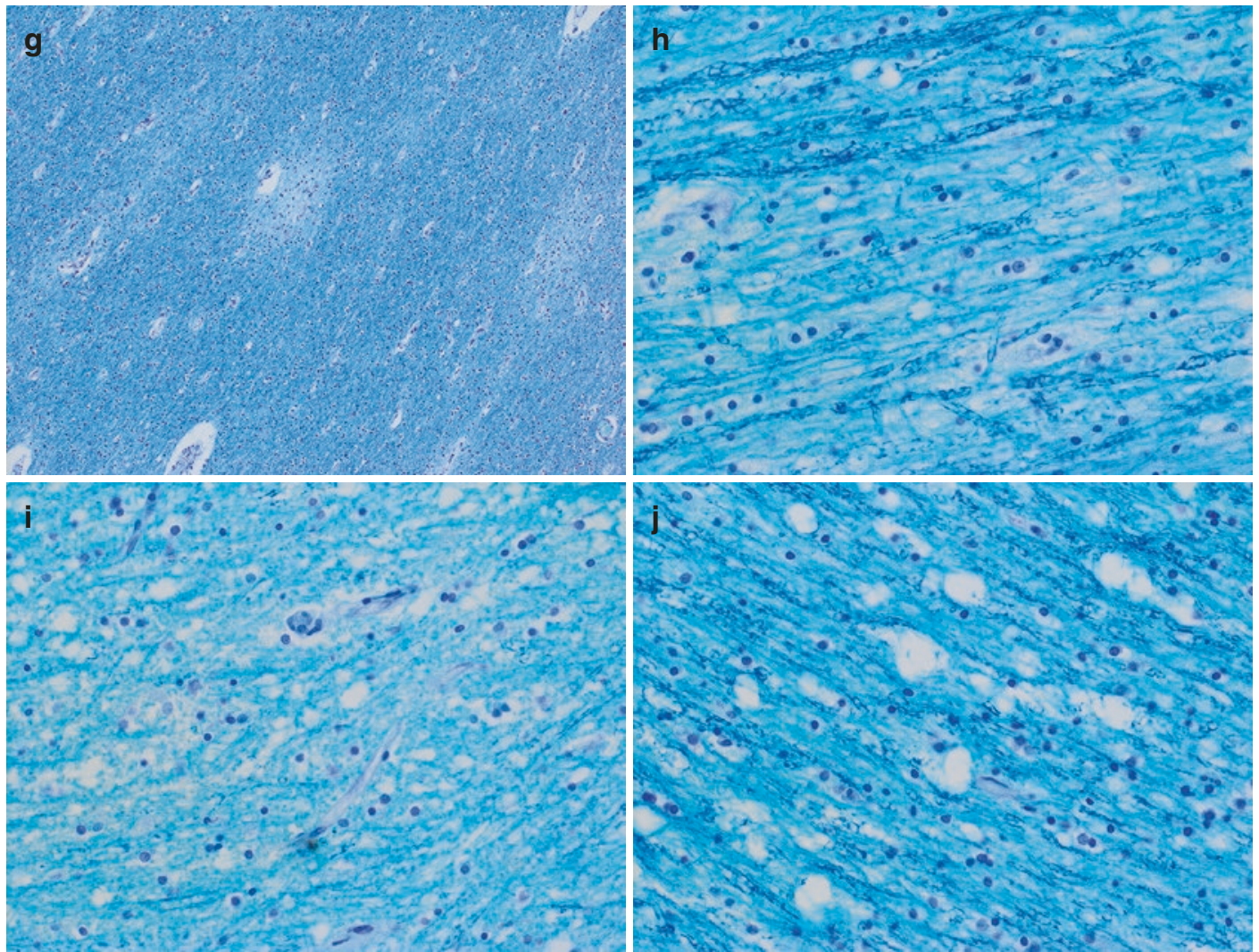

Fig. 26.4 (continued)

- Microcephaly and/or brain atrophy is present.

- The most common findings in brains of HIV1-infected children are

- Mineralization of predominantly small vessels found in $95 \%$ of the case.

- Myelin pallor and gliosis are the noted changes of the white matter that occur in $78 \%$ of the cases.

- MGC are seen in $62 \%$ of HIV-1-infected children.

- Opportunistic infections are comparatively uncommon.

\subsubsection{Therapy: HAART Effects and Therapy-Induced Immune Restitution Inflammatory Syndrome (IRIS)}

In 1995/1996, highly active antiretroviral therapies (HAART) were introduced which combine
- nucleoside reverse transcriptase inhibitors (NRTI)

- specifically inhibit the viral reverse transcriptase enzyme necessary for DNA chain elongation of the virus

- protease inhibitors (PI)

- prevent the production of active virus by interfering with the cleavage of proteins necessary for viral assembly

Effects of the therapy results in:

- The frequency of HIV-1-related CNS diseases has been reduced through

- the reduction of both viral load in the blood

- the reduced continuous penetration of virus into the brain (Tardieu 1999)

- HIV-positive patients live longer.

- The median survival 

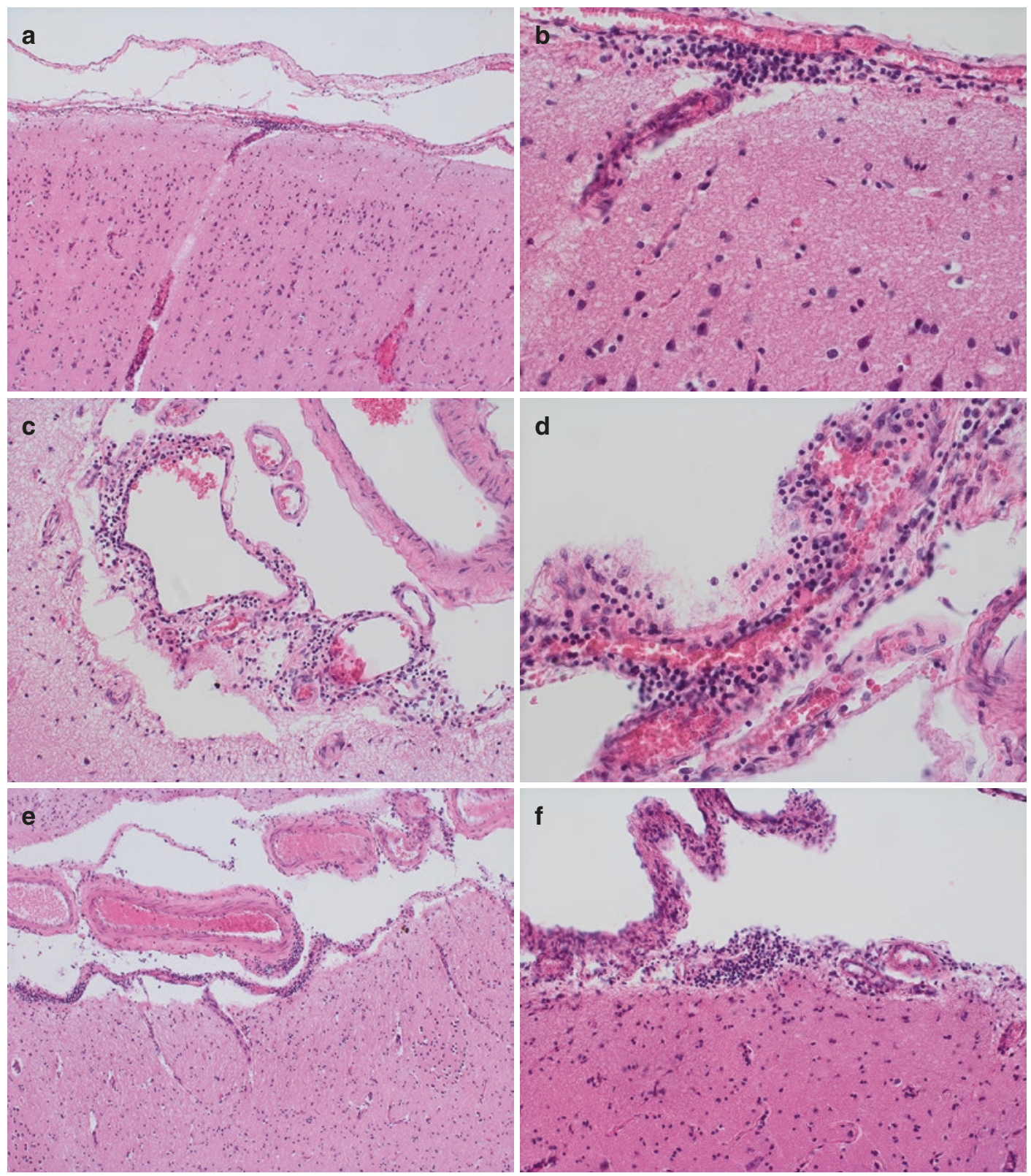

Fig. 26.5 Meningeal lymphocytic infiltrates (a-f: Stain: H\&E). Perivascular lymphocytic infiltrates (g-j: Stain: H\&E) 

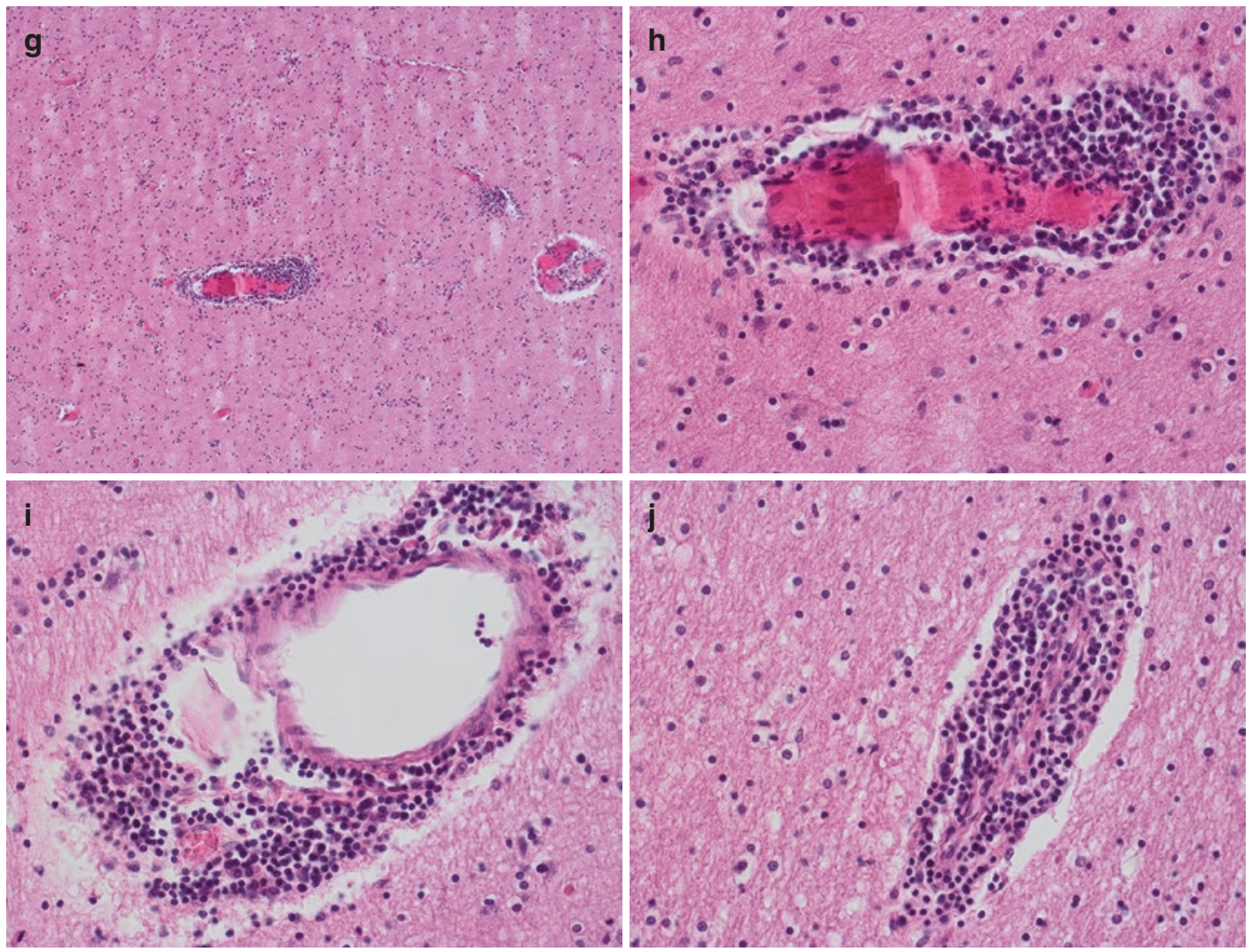

Fig. 26.5 (continued)

- following AIDS increased from 19.6 months in 1993-1995 to 39.6 months for those diagnosed in 1996-2000

- following ADC increased from 11.9 months in 1993-1995 to 48.2 in 1996-2000.

- The proportion of patients with AIDS dementia complex (ADC) increased from 5.2\% in 1993-1995 to $6.8 \%$ in $1996-2000$.

Larger cohort autopsy studies of HIV-infected patients over longer time periods suggest that, despite the beneficial effects of modern antiretroviral combination therapy, involvement of the brain in AIDS subjects continues to be a frequent autopsy finding (Gray et al. 1988, 2003; Jellinger et al. 2000; Langford et al. 2003) (Tables 26.12 and 26.13).
Immune reconstitution inflammatory syndrome (IRIS) is a syndrome that emerges when the immune system recovers after an immune deficiency state (Table 26.14) (Nelson et al. 2017; Chahroudi and Silvestri 2012; McCarthy and Nath 2010). IRIS is an adverse clinical manifestation that occurs in HIV-infected individuals treated successfully with ART and consists of a paradoxical deterioration of clinical status despite improved CD4-T-cell counts and immunologic conditions.

A new variant of HIVE has emerged in the era of HAART as a severe leukoencephalopathy with significant perivascular infiltration of macrophages and lymphocytes which is assumed to be the result of an exaggerated response from a newly reconstituted immune system (Persidsky and Gendelman 2003). 

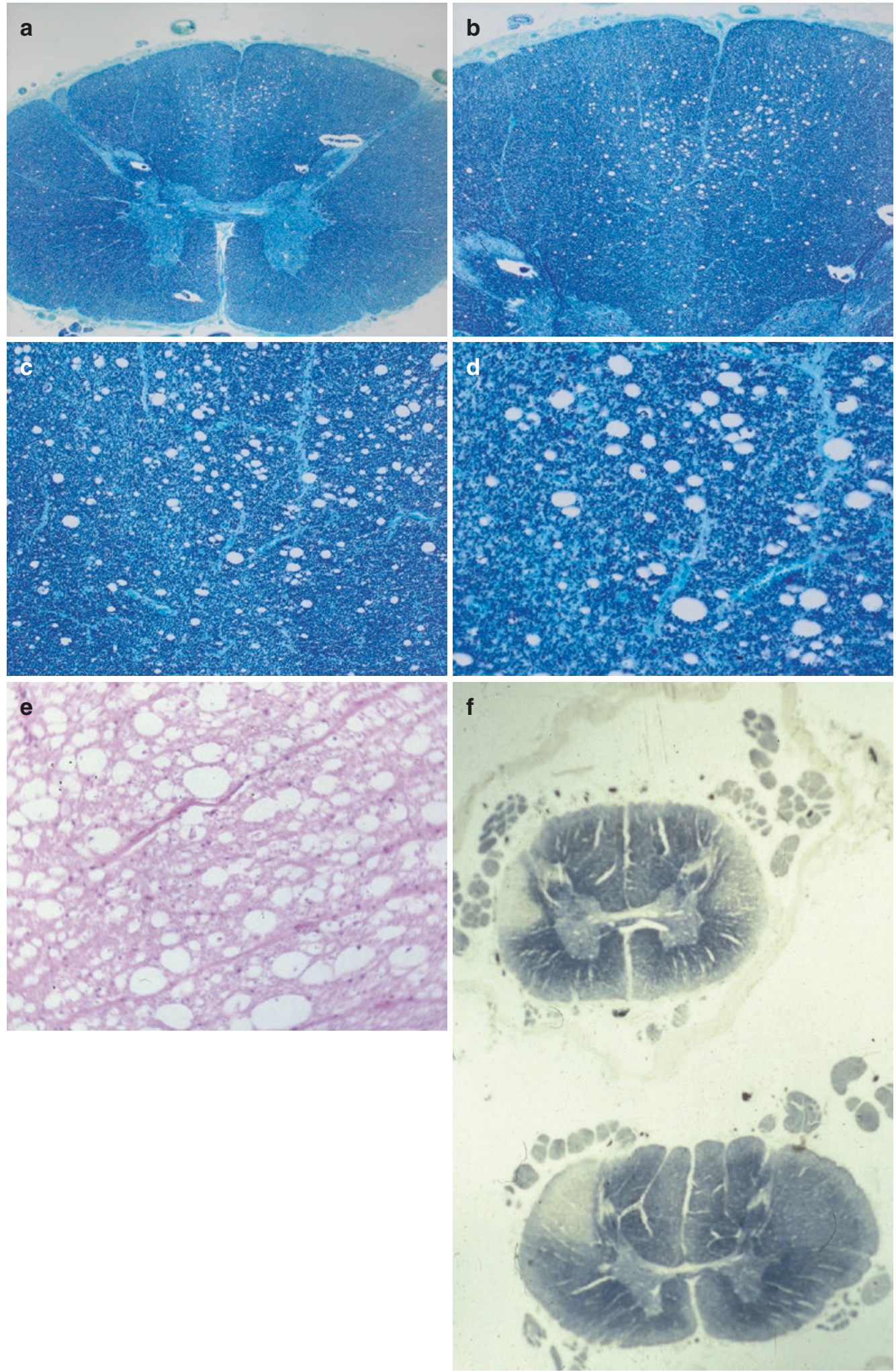

Fig. 26.6 Spinal cord showing vacuolar myelopathy of the dorsal tracts (a-d: stain LFB, e: stain H\&E, f: stain: Woelcke's myelin stain) 
Table 26.12 Review of 1597 consecutive autopsies of HIV-1-positive patients performed between 1984 and 2000 , and division into four time periods on the basis of the therapeutic regimens available (Vago et al. (2002) reproduced with kind permission by Wolters Kluver Health)

\begin{tabular}{l|l|l|l|l}
\hline Year & Therapy & $n$ & $\begin{array}{l}\text { HIV-- } \\
\text { E/L }\end{array}$ & $\begin{array}{l}\text { Opportunistic } \\
\text { infections }\end{array}$ \\
\hline $\begin{array}{l}1984- \\
1987\end{array}$ & No therapy & 119 & 53.8 & 40.3 \\
\hline $\begin{array}{l}1988- \\
1994\end{array}$ & Monotherapy (zidovudine) & 1116 & 32.2 & 46.8 \\
\hline $\begin{array}{l}1995- \\
1996\end{array}$ & $\begin{array}{l}\text { Dual combination therapy with nucleoside reverse transcriptase } \\
\text { inhibitors }\end{array}$ & 256 & 17.9 & 42.6 \\
\hline $\begin{array}{l}1997- \\
2000\end{array}$ & $\begin{array}{l}\text { Triple combination therapy including two NRTIs and at least one } \\
\text { protease inhibitor or non-NRTI }\end{array}$ & 106 & 15.1 & 42.5 \\
\hline
\end{tabular}

Table 26.13 Frequencies for various neuropathological changes in pre-HAART era compared to HAART era

\begin{tabular}{l|l|l|l|l|l|l|l|r}
\hline Author (year) & & $n$ & HIVE & HIVL & CMV & PML & TOXO & LYM \\
\hline Gray et al. (1988) & Pre-HAART & 40 & 37.5 & Nip & 20.0 & 5.0 & 47.5 & 2.5 \\
\hline Gray et al. (2003) & HAART & 23 & 17.4 & Nip & 8.7 & 17.4 & 13.0 & 13.0 \\
\hline Jellinger et al. (2000) & Pre-HAART & 352 & 8.5 & 4.3 & 18.5 & 7.1 & 22.2 & 8.5 \\
\cline { 2 - 10 } & HAART & 98 & 8.0 & 5.0 & 11.0 & 5.0 & 8.0 & 6.0 \\
\hline Langford (2003) & Pre-HAART & 62 & 25.8 & Nip & 16.1 & 6.4 & 6.4 & 19.3 \\
\cline { 2 - 10 } & HAART & 89 & 43.8 & Nip & 16.8 & 5.6 & 0.0 & 8.9 \\
\hline
\end{tabular}

$n$ sample size, HIVE HIV-1 encephalitis, HIVL HIV-1 leukoencephalopathy, $C M V$ cytomegalovirus encephalitis, $P M L$ progressive multifocal leukoencephalopathy, TOXO toxoplasma gondii encephalitis, LYM primary non-Hodgkin lymphoma

${ }^{a}$ Frequencies for pre-HAART could not be calculated due to lack of original data in their paper

Table 26.14 Clinical manifestations of IRIS in patients with HIV-1 infection on cART modified after McCarthy and Nath (2010) reproduced with kind permission by Springer Nature

\begin{tabular}{|c|c|c|}
\hline Infection & Typical clinical manifestations & Atypical clinical manifestations \\
\hline HIV encephalitis & $\begin{array}{l}\text { - Asymptomatic } \\
\text { - } \text { Mild cognitive decline }\end{array}$ & $\begin{array}{l}\text { - Fulminant decline in mental status over days with brain } \\
\text { swelling and inflammation }\end{array}$ \\
\hline PML with JCV & $\begin{array}{l}\text { - Subacute focal neurologic } \\
\text { deficits }\end{array}$ & - Focal areas of contrast enhancement and swelling \\
\hline $\begin{array}{l}\text { Varicella-zoster } \\
\text { virus }\end{array}$ & $\begin{array}{ll}\text { - } & \text { Shingles } \\
\text { - } & \text { CNS vasculitis }\end{array}$ & - Strokes without skin rash \\
\hline Cytomegalovirus & $\begin{array}{ll}\text { - } & \text { Retinitis } \\
\text { - } & \text { Cerebritis }\end{array}$ & - Vasculitis \\
\hline Epstein-Barr virus & - CNS lymphoma & - Optic neuropathy \\
\hline Tuberculosis & - Meningitis & $\begin{array}{l}\text { - } \text { Cerebral infarcts } \\
\text { - Subarachnoid hemorrhage }\end{array}$ \\
\hline Cryptococcus & - Meningitis & - Enhancing mass lesions in posterior fossa \\
\hline Candida & - Meningitis & - Vasculitis with strokes \\
\hline
\end{tabular}


Neuropathological examination revealed

- Severe inflammatory lesions.

- Demyelinating lesions with marked intraparenchymal and perivascular infiltration by macrophages and T-lymphocytes.

- In some cases, abundant viral proliferation was identified by immunocytochemistry or in situ hybridization, but in others the infectious agent could only be detected using PCR.

- T-lymphocytes were predominantly CD8(+).

- In those cases with the more favorable course, inflammation was less severe with marked macrophage activation and a number of CD4(+) lymphocytes.

- In the lethal cases, inflammation was severe and mostly composed of CD8(+) cytotoxic lymphocytes.

\subsubsection{The Sequalae of HIV-1 Infection of the Nervous System}

In summary, the following changes of the brain have been described to be due to the HIV-1 infection:

- Brain weight (Weis, unpublished data)

- no changes

- Brain edema (Weis, unpublished data)

- no significant difference

- Gross-anatomy (Gelman and Guinto 1992)

- No apparent macroscopical signs of atrophy are seen by bare visual inspection.

- Cerebrospinal fluid (CSF) space greater than two standard deviations above the mean of the age-matched control subjects.

- CSF spaces expanded most in the frontal and temporal lobe.
- Ventricular system (Weis, unpublished data) (Gelman and Guinto 1992)

- Widening of the lateral ventricles.

- Ventricular spaces expanded more than the sulcal spaces.

- Volume of brain regions (Oster et al. 1993;

Subbiah et al. 1996; Weis et al. 1993c)

- No significant changes in volume, surface area, mean cortical thickness.

- Reduction of the mean volume of the neocortex.

- Reduction in volume of the central brain nuclei.

- Reduction in volume of the internal capsule.

- Mean neocortical thickness was reduced by $12 \%$.

- There were no differences in white matter volumes between groups.

- The mean volume of the white matter was reduced by $13 \%$.

- Mean ventricular volume was increased by $55 \%$.

- There were no significant differences between the AIDS groups with and without HIV-associated dementia.

- Neuronal number

- Cerebral cortex (Ketzler et al. 1990; Weis et al. 1993b)

- Loss of neurons in different cortical regions.

- Neuronal loss is not be correlated with development of dementing symptoms and of HIV-specific neuropathology.

- Basal ganglia

○ decrease in neuronal density (21\%) in the putamen especially in those cases with HIV-1 encephalitis (Everall et al. 1993). 
- Cerebellum

- significant reduction of the volume density, the numerical density of neurons as well as neuronal size was apparent in the cerebellar dentate nucleus and in both inferior olivary nuclei (Abe et al. 1996)

- Substantia nigra

- The total number of neuronal cell bodies was $25 \%$ lower in AIDS than in agematched controls although the volume density of neuronal melanin did not differ from that of controls because the percentage of pigmented cell bodies was higher and the cell bodies were more fully packed with melanin in AIDS (Reyes et al. 1991).

- The size of total neurons (pigmented and non-pigmented neurons) and of pigmented neurons was significantly reduced in all investigated nuclei (anteromedial, antero-intermediolateral, posterolateral, and posteromedial nuclei) of HIV-1-infected brains.

- Furthermore, the nigral neuronal loss showed no relationship with immunohistochemical detection of HIV-1 antigens (gp41, p24).

- The numerical density of non-pigmented large neurons (type II neurons) was significantly increased in HIV-1infected brains suggesting that (1) nonpigmented, dopaminergic neurons or non-pigmented, non-dopaminergic neurons might be relatively preserved in the $\mathrm{SN}$ of HIV-1 infection, or (2) that pigmented dopaminergic neurons loose their melanin pigments during the early stages of degeneration, which also might be responsible for functional deterioration (Itoh et al. 2000).

- Neuronal size (Weis et al. 1993b)

- no changes in perikaryal size

- Synapses (Wiley et al. 1991)

- Loss of synapses as shown by a decrease in the immunoreactivity against synaptophysin

- Dendrites (Masliah et al. 1992a, b)

- Apical dendrites
- dilated, vacuolated, and tortuous

- decreased length and branching

- Basal and oblique dendrites

- show the same alterations, but to a lesser extent

- Some dendrites present lacunae and filopodia consistent with remodeling.

- 40-60\% decrease in spine density throughout the entire length of dendrites.

- Fewer spines on neurons; 55\% fewer on the first segment, $40 \%$ fewer on the second, $45 \%$ fewer on the third, $60 \%$ fewer on the fourth, and $65 \%$ fewer in the fifth segment.

- Aberrant spines in regions of abnormal second-order dendritic branches.

- Nerve fibers

- White matter

- Loss of nerve fibers in the white matter

- Corpus callosum (Wohlschlaeger et al. 2009)

- Reduced thickness of the myelin sheath of nerve fibers in the corpus callosum.

- Calculation of the $g$-ratio revealed a relative increase in size of the axon and a relative decrease in the myelin sheath thickness.

- The data indicated a reduction in the size of nerve fibers and axons as well as thinner myelin sheaths, whereas in other callosal regions axons and myelin sheaths were swollen and enlarged.

- These changes were observed in regions which are unaffected, as revealed by light-microscopic analysis of sections stained for myelin.

- Optic nerve (Tenhula et al. 1992)

- Degeneration was often severe and was scattered throughout all of the AIDSaffected optic nerves.

- Despite the approximate $40 \%$ loss of axons in the AIDS-affected optic nerves, the mean axonal population was markedly lower than the mean obtained from normal optic nerves $(880,000$ vs. $1,507,000)$.

- The mean axonal diameters were not markedly different, that the changes may not only be secondary to damage at the 
retina, but may reflect an AIDS-associated primary optic neuropathy.

- Astroglia (Weis et al. 1993a; Ciardi et al. 1990)

- no change in the number of all astrocytes (i.e., GFAP-positive and GFAP-negative astrocytes)

- reduction of the number of GFAP-negative cells

- increase of reactive GFAP-positive astrocytes

- not correlated with loss of nerve cells

- increase in nuclear size of GFAP-negative and GFAP-positive astrocytes

- increase of the size of the cytoplasm of GFAP-positive astroglia

- no correlation between the neuronal loss and the pattern of reactive astrocytosis

- Oligodendroglia (Esiri et al. 1991)

- significant increase in the number of oligodendrocytes associated with mild degree of myelin damage

- decrease of oligodendrocytes in severely affected areas

- slight increase in immunoreactivity for the enzymes carbonic anhydrase II and 2', $3^{\prime}$ cyclic nucleotide $3^{\prime}$-phosphodiesterase

- significant increase in the numerical density of transferrin-immunopositive cells of the white matter

- an initial reactive hyperplasia which may represent an attempt to repair myelin damage taking place already early during the HIV-1 infection

- Microglia/macrophages (Weis et al. 1994)

- Activated in gray and white matter of all brain regions.

- Activation pattern is not correlated with the presence of HIV-antigen gp41 and p24 in the brain tissue.

- Vessels (Buttner et al. 1996; Weis et al. 1996)

- Significant increase in the diameter of cortical vessels

- Increase of the volume fraction, surface area of vessels

- No changes in length density indicating no changes in the number of vessels
- Increase of the numerical density of vessels in the gray matter

- No changes in the numerical density of vessels in the white matter

- Thinning of the basal lamina as seen by electron microscopy

- Reduced immunoreactivity for collagen IV and laminin (thinning of the basal lamina)

- Vascular endothelial cell (Buttner et al. 1996;

Weis et al. 1996)

- loss of glycoproteins SBA, UEA-I, and WGA of the endothelial cell membrane

- decrease of immunoreactivity for von Willebrand factor (Factor VIII)

- no significant differences RCA-I

- No changes in size at the electron microscopic level

- Capillaries (Weis and Haug 1989)

- region-specific changes

- increased capillary profile area

- increased capillary diameter

- decreased basal lamina thickness

- increased endothelial cell size

- unchanged pericyte size

\subsubsection{Pathogenetic Mechanisms}

\subsubsection{Mode of Entrance of HIV-1 to the Brain}

HIV-1 enters the CNS by

- HIV-1 is passively carried by T-lymphocytes and monocytes-the "Trojan Horse" hypothesis.

- Cell-free HIV-1 particles may also penetrate brain microvascular endothelial cells.

- After crossing the BBB into the CNS, macrophages spread productive HIV-1 infection to neighboring microglia.

- Microglia serve as

- a reservoir for persistent viral infection and replication

- a vehicle for viral dissemination throughout the brain

- a major source of neurotoxic products that affect glial function, the blood-brain 
barrier and neuronal function, and finally lead to cell death

- Microglia and monocyte-derived macrophages express both the CD4 and chemokine coreceptors (CCR5, CXCR4), the prerequisite for HIV-1 to enter a cell.

- The potential role of the cerebrospinal fluid or the choroid plexus as a means for HIV-1 entry in the brain is still unclear.

- At the time of primary HIV-1 infection, an acute aseptic meningitis or encephalitis indicates central nervous system invasion.

- The point in time when the migration of HIV-1-infected lymphocytes into the brain takes place is not known. It has been shown that, at the time of seroconversion, HIV-1 can be detected in the CSF; this is the time when, clinically, a subacute meningitis develops, thus, suggesting that HIV-1 enters the CNS at a very early stage of the disease.

- Opportunistic infectious agents or drugs of abuse disturbing the BBB may further attract more HIV-1-infected T-lymphocytes and macrophages into the brain.

\subsubsection{Target Cells of HIV-1 Infection}

The cells in the brain identified to contain HIV-1 are:

- Microglia

- Macrophages

- Multinucleated giant cells

- Astrocytes (possibly)

- Endothelial cells (possibly)

- Oligodendrocytes (possibly)

\section{Mechanisms of Brain Lesions}

- The development of brain lesions due to opportunistic infections and lymphomas might be explained by the lack of a competent immunologic defense system.

- One might assume that the changes described in Sect. 26.5.8 might result by direct infection with HIV-1.

- However, it has been shown that neither neurons, nor astrocytes nor endothelial cells are infected with HIV-1.
- Thus, these changes more probably result from indirect toxic factors that are produced either by infected multinucleated giant cells or by activated microglia.

- Neuronal dropout occurs in brain regions

- That are free from any neuropathological changes.

- Neuronal damage in AIDS was, at least, partly due to apoptosis.

- No correlation was found between the presence and severity of neuronal loss or of neuronal apoptosis and a history of cognitive disorders.

- No correlation between the presence of HIV-1 proteins and neuronal loss.

- The reactive astrogliosis was not correlated with the loss of nerve cells, indicating that this reaction pattern is rather a response to toxic factors secreted into the brain tissue.

- The number of activated microglia/macrophages is significantly increased in all brain regions. This activation of microglia is not correlated with the presence of HIV-1 antigen in the brain tissue. Activated microglia/macrophages, rather than MGCs, most probably secrete toxic factors.

- The neurotoxicity associated with HIV-1 infection is mediated, in part, through

- cytokines

- arachidonic acid metabolites

- produced during cell-to-cell interactions between HIV-1-infected brain macrophages and astrocytes

- Pathobiological events underlying the neurodegenerative processes in HIV-1-associated dementia are believed to begin with productive infection of monocytes/macrophages by HIV-1.

- Peripheral activation causes the differentiation of macrophages to produce a variety of immune products that lead to the upregulation of adhesion molecules on brain microvascular endothelial cells and the expression of adhesins on the monocyte-macrophage cell surface.

- After penetration of the BBB, the differentiated brain macrophages and microglia can be vehicles for viral dissemination 
throughout the brain and focal reservoirs for productive HIV-1 replication.

- The neurotoxic events in the brain are caused by neurotoxins produced by these cells which are primed by HIV-1 and secondarily activated by factors such as immune stimuli or by T-cells trafficking through the nervous system.

- The primed and immune-activated brain macrophages/microglia secrete a variety of factors which affect neural and glial function and eventually lead to CNS inflammation.

- A pro-inflammatory cytokine response from blood-derived monocytes/macrophages, microglia, and astrocytes is amplified and leads finally to neurodegeneration.

- Immune neurotoxic factors may contribute to the breakdown of the BBB and affect the generation of chemokines, leading to transendothelial migration of monocytes into the brain perpetuating the inflammatory cascade.

- As a result of the neurotoxic activities of activated macrophages/microglia, astrocytes may suppress or increasemacrophages/microglia secretory functions and toxicity, depending on the astrocytic functional status.

- Cytolytic T-lymphocytes serve to eliminate infected cells, but are lost in late-stage HIV-1 disease, allowing the virus-induced, neurodegenerative response to continue unabated.

- Other factors include:

- viral proteins

- $\mathrm{CA}^{2+}$ channels

- NMDA receptors

- chemokines and cytokines

- Expression of developmental proteins (Malik and Eugenin 2016):

- Dickkopf homolog 1 (DKK1): upregulated

- Rho-associated, coiled-coil containing protein kinase 2 (ROCK2) - upregulated

- Low density lipoprotein receptor-related protein-associated protein 1 (LRPAP1) upregulated

- Low density lipoprotein receptor-related protein 5-like (LRP5L) — downregulated

- Low density lipoprotein-related protein 12 (LRP12)—upregulated
- Low density lipoprotein receptor-related protein 8, apolipoprotein e receptor (LRP8)—downregulated

- Catenin (cadherin-associated protein), alphalike 1 (CTNNAL1) - upregulated

- Catenin, beta-like 1 (CTNNBL1)downregulated

- Catenin (cadherin-associated protein), delta 1 (CTNND1)—downregulated

- Catenin (cadherin-associated protein), alphalike 1 (CTNNAL1) - upregulated

- Glycogen synthase kinase 3 beta (GSK3B) downregulated

- Wingless-type MMTV integration site family, member 10A (WNT10A) downregulated

- For more details, see (Zayyad and Spudich 2015; Singh 2016; Ru and Tang 2017; Rao et al. 2014; Malik and Eugenin 2016; Lamers et al. 2016; Joseph et al. 2016; Chen et al. 2014; Carroll and Brew 2017).

Interactions between the blood-brain barrier (BBB) and HIV (Hong and Banks 2015)

Mechanisms involving the $\mathrm{BBB}$ in HIVinfection

- Passage of HIV cell-free virus across the BBB

- Transcytotic (mannose 6 phosphate receptor dependent)

- Paracellular (tight junction dissolution)

- Passage of HIV-1 proteins (gp120, Tat) across the BBB

- Increased immune Ccll trafficking across the BBB

- Activated and infected T cells

- Activated and infected monocytes

- Transport of cytokines across the BBB

- Induction of cytokine release from barrier cells

- Increased BBB leakiness

- Brain-to-blood efflux of antivirals

- Protease inhibitors by P-glycoprotein

- AZT by organic ion transporter

- Altered BBB transporter expression and function (e.g., P-glycoprotein)

- Neurovascular unit effects 
Table 26.15 Therapy and effects on involved pathways (Sanchez and Kaul 2017) reproduced with kind permission from MDPI open access

\begin{tabular}{l|l|l|l}
\hline & HIV or methamphetamine or HIV + Meth & HIV + cART & HIV + METH + cART \\
\hline Microglia activation & $\uparrow$ & $\uparrow$ & $\uparrow$ \\
\hline Astrocytosis & $\uparrow$ & $\uparrow$ & $\uparrow$ \\
\hline $\begin{array}{l}\text { Alteration of } \\
\text { neurotransmission }\end{array}$ & $\uparrow$ & & $\uparrow$ \\
\hline HAND/HAD & $\uparrow$ & $\downarrow$ & \\
\hline Oxidative stress & $\uparrow$ & $\uparrow$ & $\uparrow$ \\
\hline Mitochondrial impairment & $\uparrow$ & & \\
\hline ER stress & & $\uparrow$ & \\
\hline Autophagy & & & $\downarrow$ \\
\hline Neuronal dendrites & $\downarrow$ & & $\downarrow$ \\
\hline Synapses & $\downarrow$ & & $\downarrow$ \\
\hline Neuronal ATP & $\downarrow$ & $\downarrow$ & $\downarrow$ \\
\hline Viral load & & $\downarrow$ & \\
\hline
\end{tabular}

Therapeutic effects on involved pathways are illustrated in Table 26.15.

\subsection{DNA-Virus: Cytomegalovirus Infection (CMV)}

\section{Cytomegalovirus}

- Herpesviruses, subfamily Betaherpesvirinae

- Large, enveloped viruses containing doublestranded DNA

- $150 \mathrm{~nm}$ in diameter

\subsubsection{Neuroradiology Findings}

\section{General Imaging Features}

- Periventricular white matter lesions, subependymal enhancement

- Calcifications in perinatal CMV

CT Non-Contrast-Enhanced (Fig. 26.7a)

- Periventricular hypodense lesions

- Periventricular hyperdense calcifications in perinatal CMV

\section{CT Contrast-Enhanced}

- Subependymal enhancement possible

MRI-T2/FLAIR (Fig. 26.7b, c)

- Periventricular hyperintensities
MRI-T1 (Fig. 26.7e)

- Subependymal enhancement

MRI-T1 Contrast-Enhanced (Fig. 26.7e)

- Subependymal enhancement

MRI-T2*/SWI (Fig. 26.7f)

- Periventricular hypointense calcifications in perinatal CMV

\subsubsection{Neuropathology Findings}

\section{Macroscopic Features}

- In general, there are no gross-anatomical changes.

- Rarely, some small areas of necrosis are seen lining the ventricles, i.e., necrotizing ependymitis.

\section{Microscopic Features (Fig. 26.8a-j)}

- Microglial nodules are seen scattered throughout the nervous system.

- Large cells containing inclusion bodies are found within the microglial nodules.

- The microglial nodules located in the gray and white matter are usually not surrounded by a necrotic area.

- Along the periventricular spaces CMVcontaining cells are found within the necrotic areas. 

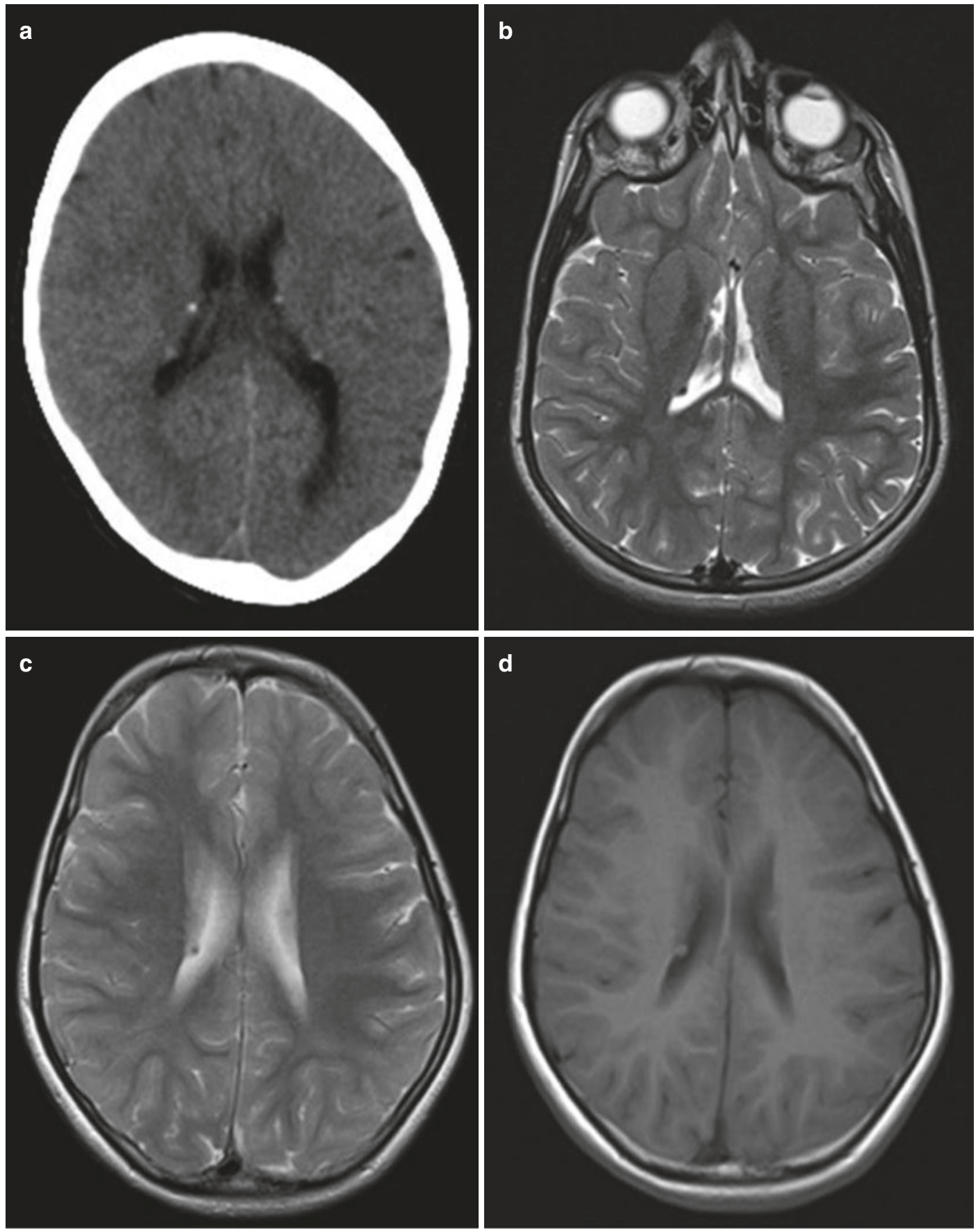

Fig. 26.7 Cytomegalovirus (CMV) infection: periventricular calcifications after perinatal CMV. CT non-contrast (a), $\mathrm{T} 2(\mathbf{b}, \mathbf{c}), \mathrm{T} 1(\mathbf{d}), \mathrm{T} 1$ contrast $(\mathbf{e}), \mathrm{T} 2 *(\mathbf{f})$ 

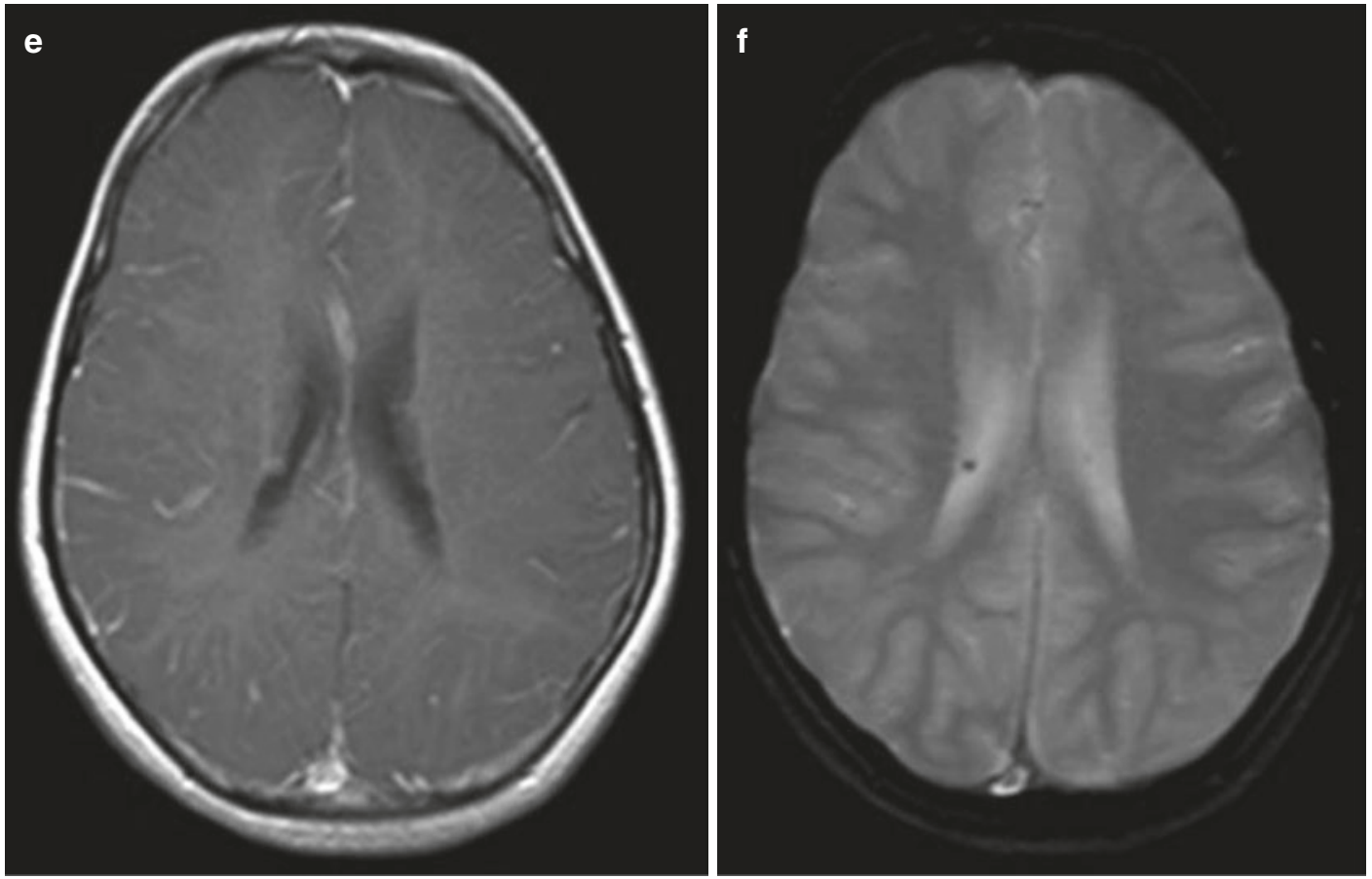

Fig. 26.7 (continued)

\subsection{Progressive Multifocal Leukoencephalopathy (PML)}

John Cunningham Virus (JCV) is a member of the Polyomaviridae family

Polyomaviruses BK and JC are ubiquitous.

- Are $45 \mathrm{~nm}$ in diameter.

- Contain less than 5000 base pairs.

- Genomes of BK and JC are closely related.

- divided in early, late, and non-coding regions

- JC virus etiological agent of the progressive multifocal leukoencephalopathy (PML)

- JC is an ubiquitous, neurotropic virus:

- 50-90\% of adult healthy individuals have been exposed to this virus.

- $19-27 \%$ of those people shedding JCV in their urine.

- The seroprevalence increases with age but acquisition of this virus is not associated with a clinical syndrome.

- JC binds to sialylated carbohydrates and serotonin receptors to enter glial cells by endocytosis.
- DNA genome is uncoated and delivered to the nucleus.

\subsubsection{Clinical Signs and Symptoms}

- The pre-AIDS era

- Impaired vision

- homonymous hemianopsia

- Motor weakness

○ hemiparesis or hemiplegia

- Changes in mentation:

- personality change

- difficulty with memory

- emotional lability

- dementia

- AIDS-related PML

- weakness $(42 \%)$

- speech abnormalities (40\%)

- cognitive abnormalities (36\%)

- gait abnormalities (29\%)

- sensory loss (19\%)

- visual impairment (19\%)

- seizures 

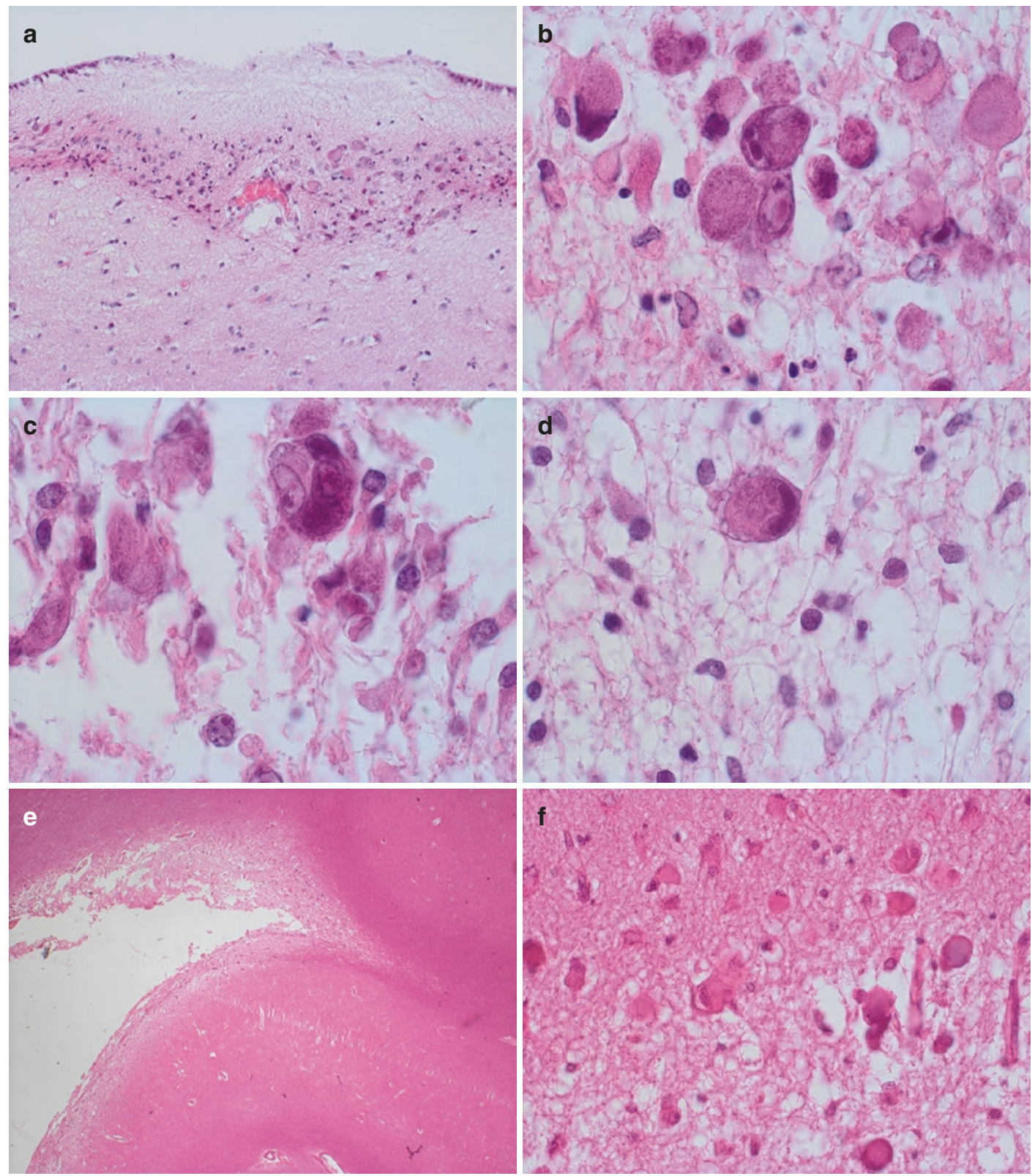

Fig. 26.8 Cytomegalovirus (CMV) infection (a-n). Cells with inclusion bodies (a-j) (stain: H\&E); cytomegalic cell with inclusion body (k-n) (stain: immunohistochemistry for CMV) 

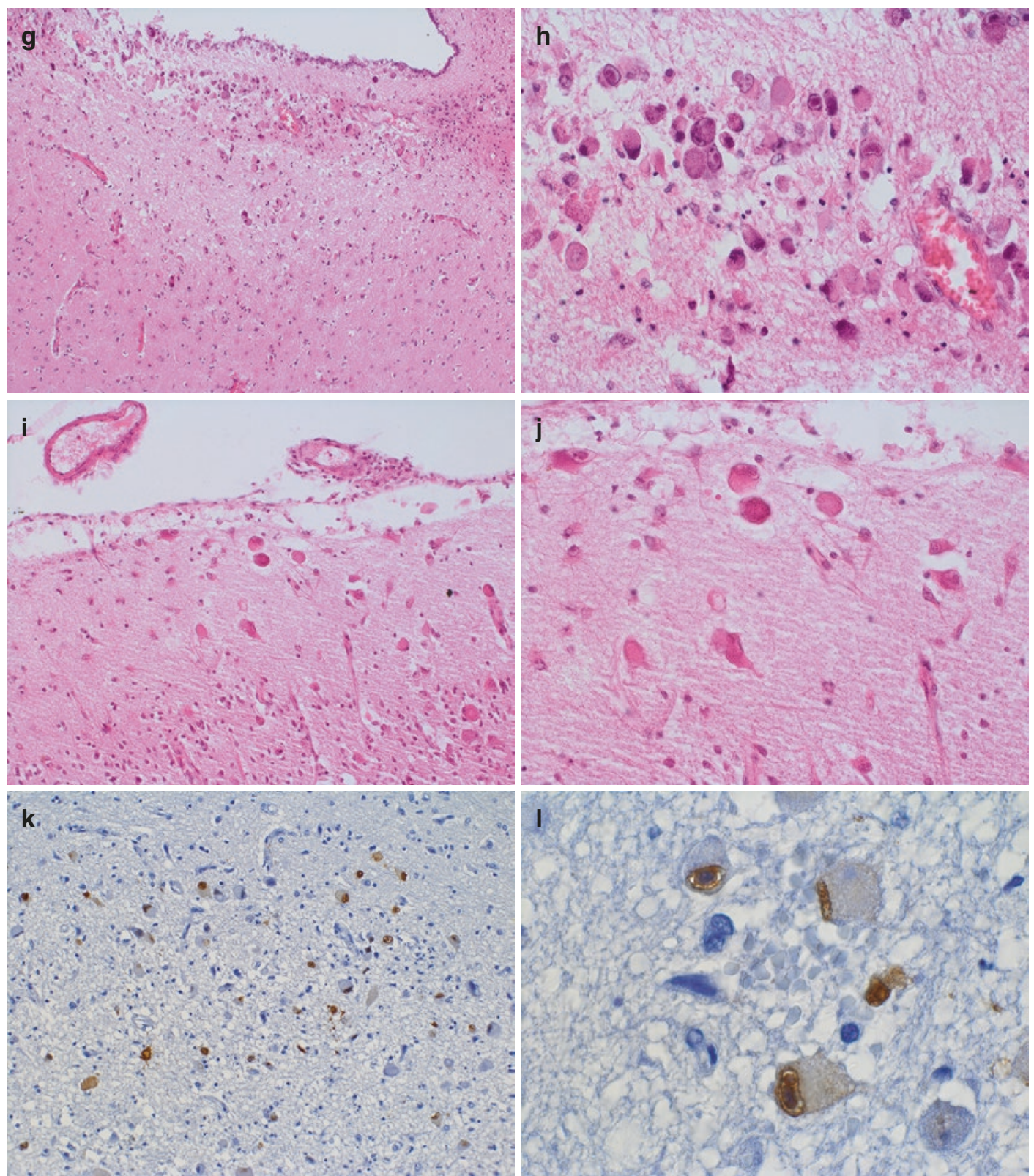

Fig. 26.8 (continued) 


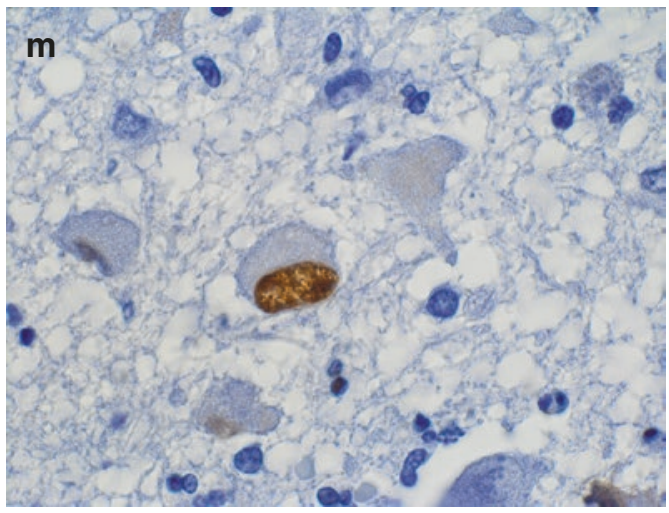

n

Fig. 26.8 (continued)

- diplopia

- limb incoordination

- PML associated with monoclonal antibody therapy

- cognitive disorders (48\%)

- motor abnormalities (37\%)

- language disturbances (31\%)

- visual defects $(26 \%)$

- PML-IRIS immune reconstitution inflammatory syndrome

- Paradoxical worsening of clinical or radiographic finding with recovery of the immune system

- New or increased neurologic deficits

- Increase in the number or size of lesions on neuroimaging

- Contrast enhancement of brain lesions

- Brain edema

- Concurrent with diagnosis of PML

\subsubsection{Neuroimaging Findings}

\section{General Imaging Features}

- Confluent subcortical white matter lesions, predominantly in parieto-occipital or frontal lobes, U-fibers involved

\section{CT Non-Contrast-Enhanced (Fig. 26.9a)}

- Multiple hypodensities in white matter

- No mass effect

- If bilateral often asymmetric

- Natalizumab-associated PML often monofocal
CT Contrast-Enhanced (Fig. 26.9b)

- Usually no enhancement

- Enhancement possible in HIV-associated PML and natalizumab-associated PML

MRI-T2 (Fig. 26.9c)

- Hyperintense

MRI-FLAIR (Fig. 26.9d)

- Hyperintense

MRI-T1 (Fig. 26.9e)

- Hypointense

MRI-T1 Contrast-Enhanced (Fig. 26.9f)

- Usually no enhancement

- Enhancement possible in HIV-associated PML and natalizumab-associated PML

MRI-DWI (Fig. 26.9g)

- Acute lesions hyperintense

MRI-ADC (Fig. 26.9h)

- Acute lesions hypointense

\subsubsection{Neuropathology Findings}

Macroscopic Features (Fig. 26.10a-d)

- Multiple areas of discoloration of the white matter.

- Sometimes, the white matter may appear softened and mottled. 

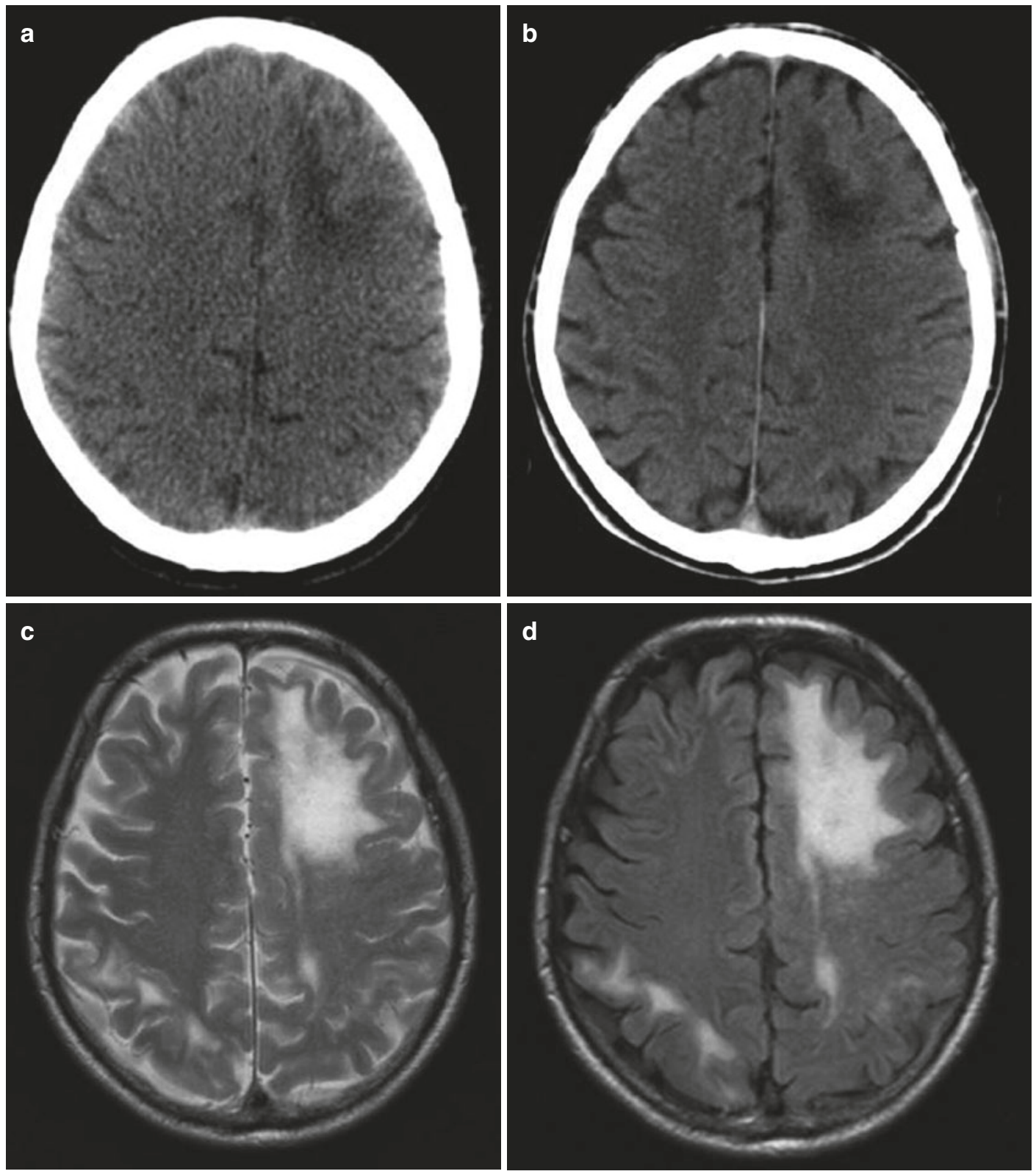

Fig. 26.9 Progressive multifocal leukoencephalopathy (PML). CT non-contrast (a), CT contrast (b), T2 (c), FLAIR (d), T1 (e), T1 contrast (f), DWI (g), ADC (h) 

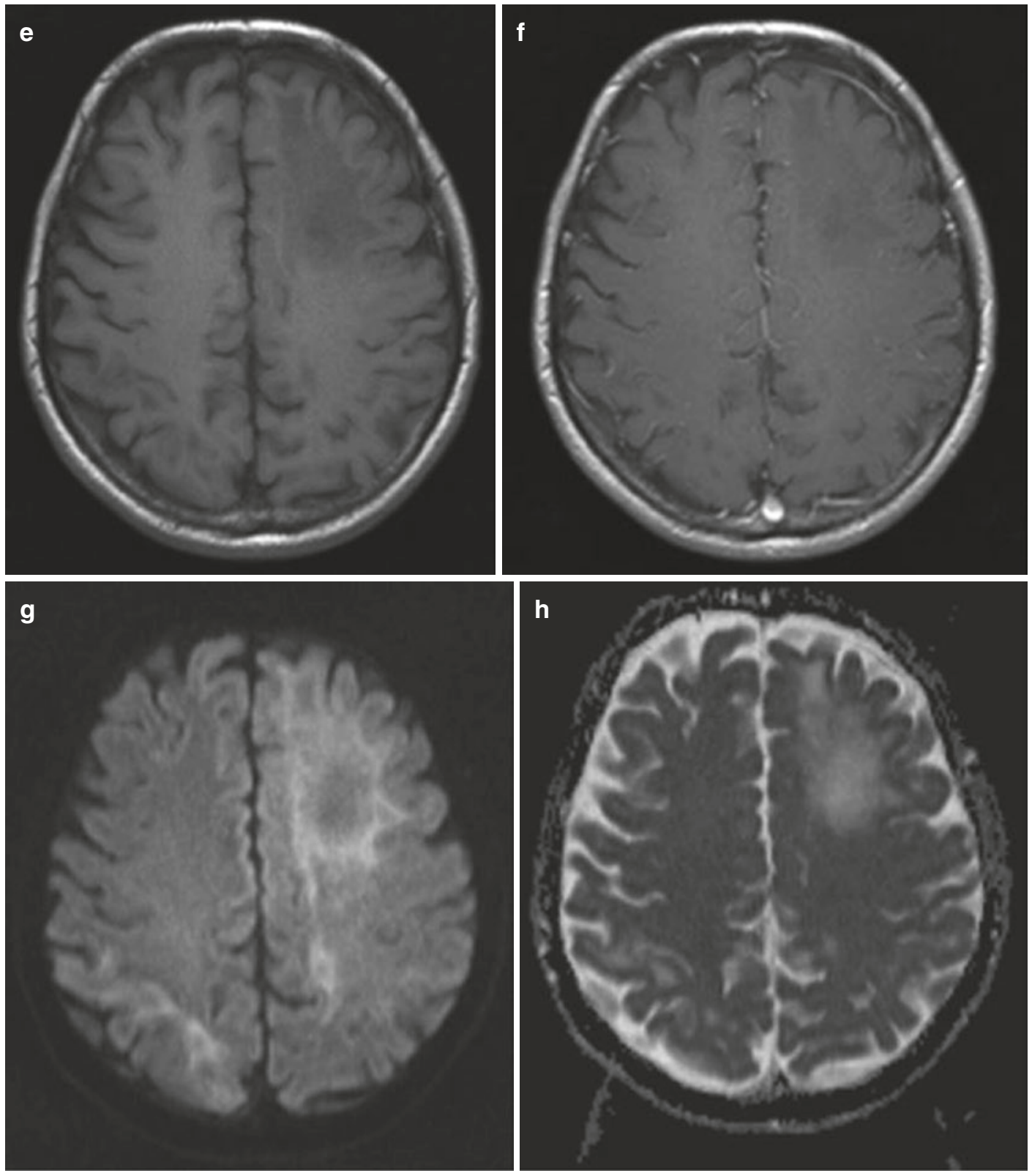

Fig. 26.9 (continued) 

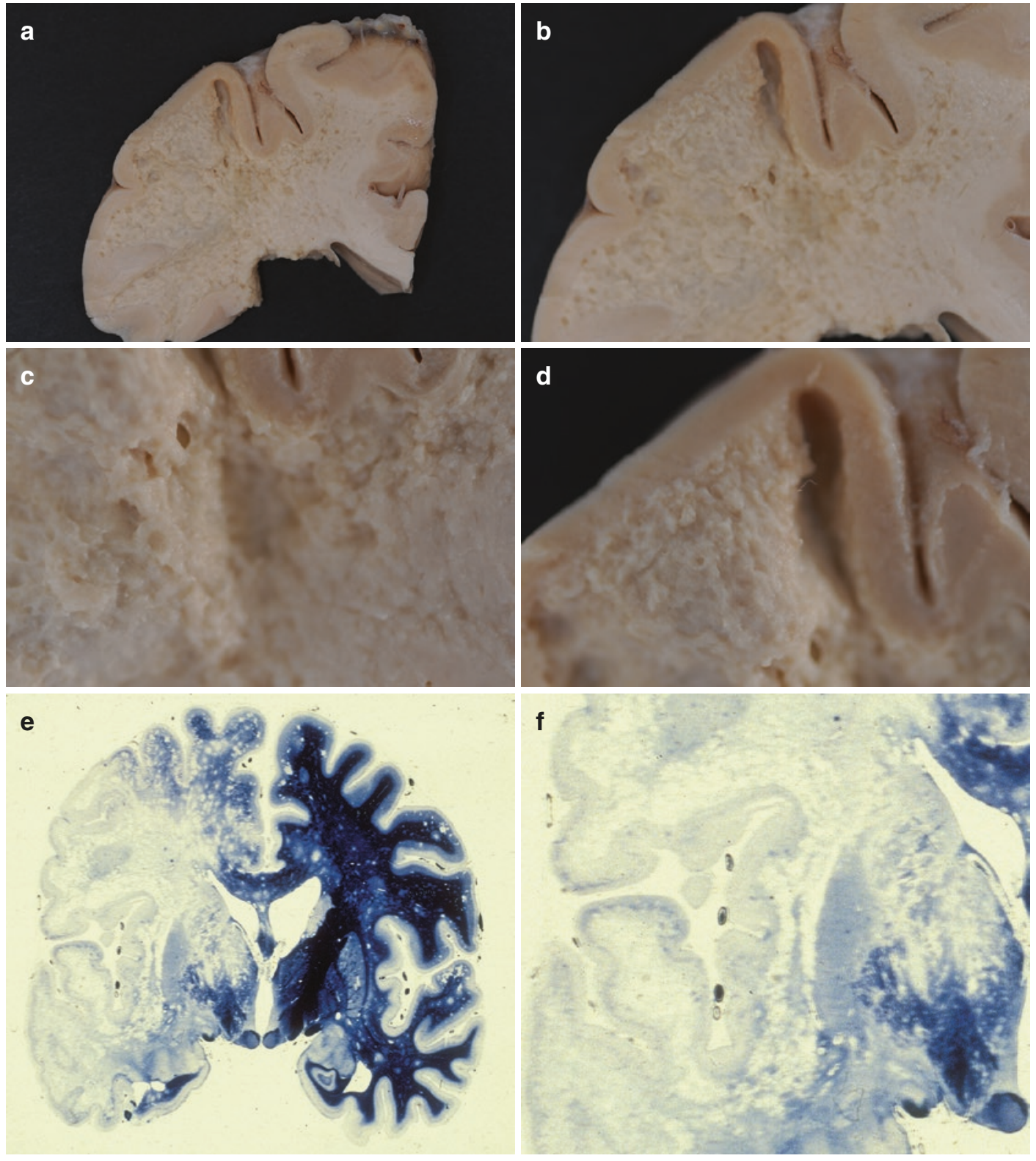

Fig. 26.10 Progressive multifocal leukoencephalopathy: macroscopically, the white matter shows a moth-eaten appearance (a-d). The myelin of the left hemisphere is completely lost (stain: Woelcke's myelin stain) (e, f). Histology shows degeneration of myelin accompanied by the presence of reactive astrocytes, bizarre astrocytes/oli-

godendrocytes with large eccentric cytoplasm and lymphocytic infiltrates (g-j). Reactive astrogliosis (stain: GFAP) (k, l) and reactive microgliosis (stain: HLA-DRII) $(\mathbf{m}, \mathbf{n})$. Lymphocytes (stain: CD45) $(\mathbf{o}, \mathbf{p})$ are found in the perivascular spaces and within the brain tissue 

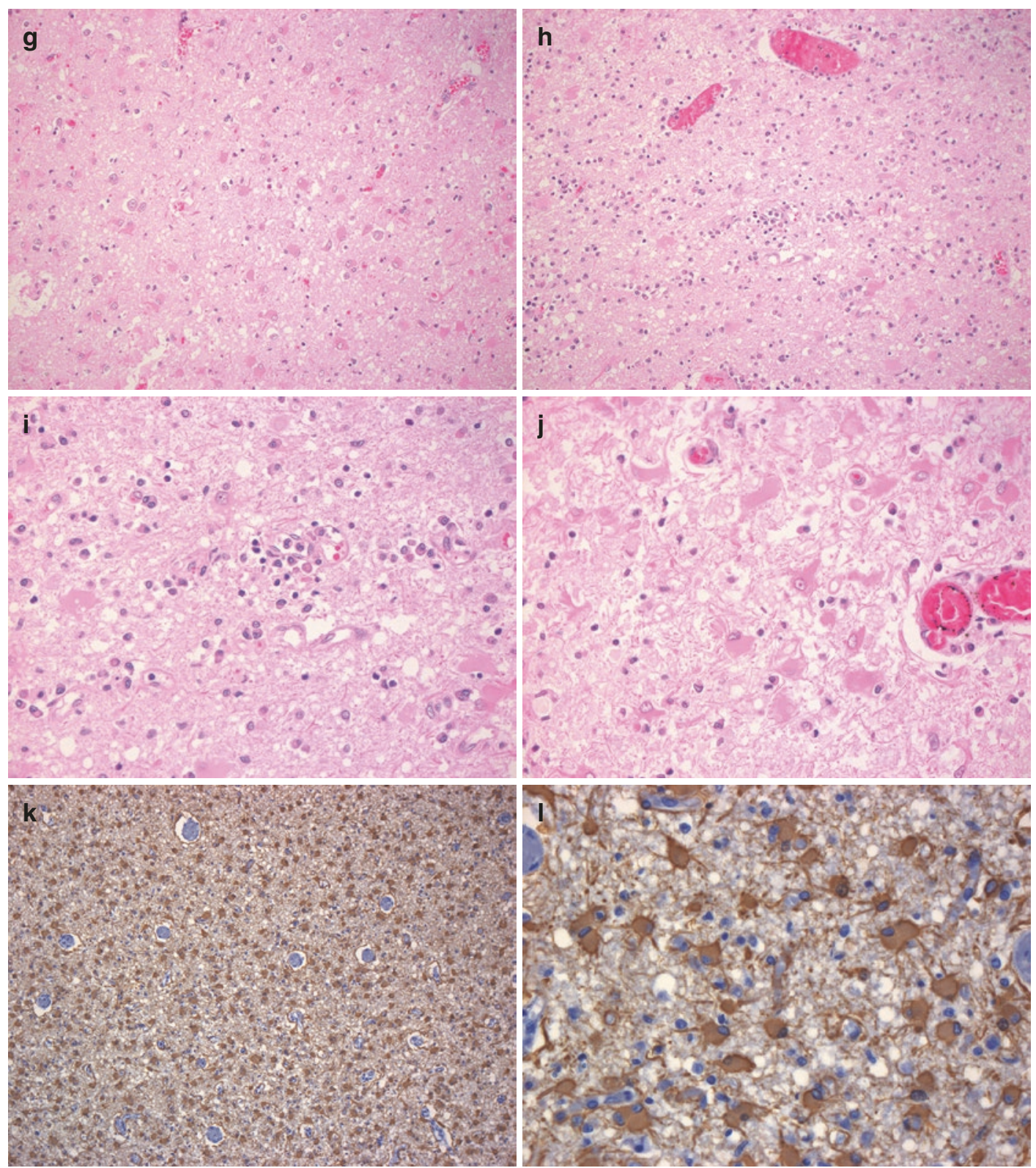

Fig. 26.10 (continued) 

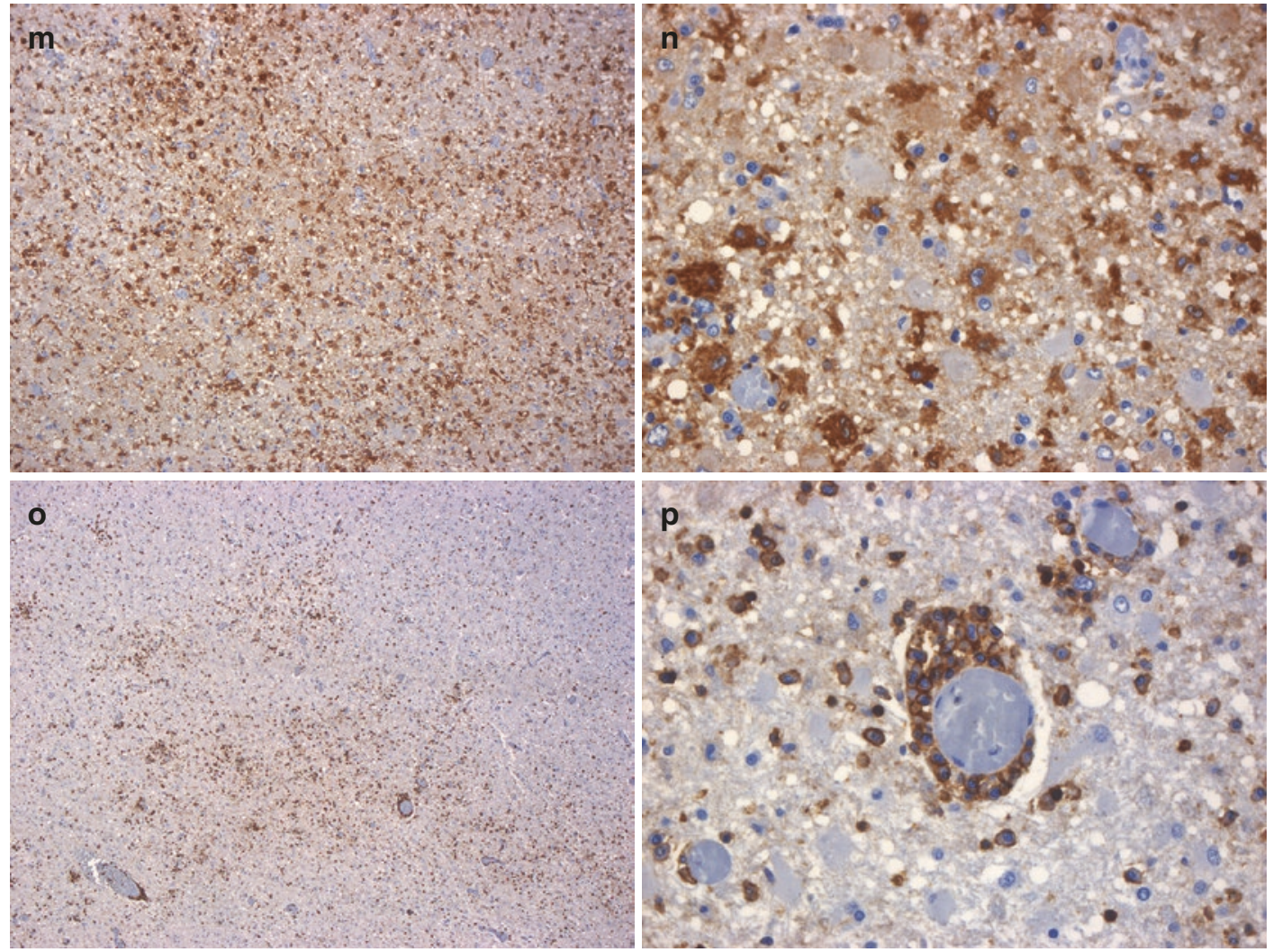

Fig. 26.10 (continued)

Microscopic Features (Fig. 26.10e-p)

- Multiple foci of demyelination in the white matter consisting of loss of myelin sheaths.

- The oligodendrocytes are enlarged, amphophilic, and contain intranuclear inclusions.

- Enlarged, bizarre astrocytes.

\subsubsection{Molecular Nauropathology}

Development of PML (Berger and Khalili 2011)

- infection with JC virus

- establishment of latent and/or persistent JC virus infection

- rearrangement of JC virus into a neurotropic strain if initial infection has been with the archetype strain

- reactivation of the neurotropic JC virus strain from sites of viral persistence/latency

- entry into the brain
- establishment of productive infection of oligodendrocytes

- ineffective immune system that prevents immunosurveillance from eliminating the infection

Drugs which cause PML are listed in Table 26.16.

The differences between progressive multifocal leukoencephalopathy (PML), progressive multifocal leukoencephalopathy-immune reconstitution inflammatory syndrome (PMLIRIS) and multiple sclerosis (MS) with regard to anatomical, neuropathological, and MRI features are shown in Table 26.17.

Prognostic factors of the evolution of progressive multifocal leukoencephalopathy have been described (Gheuens et al. 2013) and include:

- Favorable factors:

- Detectable JCV-specific cellular immune response in blood or CSF 
Table 26.16 Drug-induced cases of PML (Bauer et al. 2015) reproduced with kind permission by Springer Nature

\begin{tabular}{l|l}
\hline Medication & Treatment \\
\hline Azathioprine & Transplantation/autoimmune disease \\
\hline Cyclosporine & Transplantation \\
\hline Cyclophosphamide & Cancer/transplantation/autoimmune disease \\
\hline Dimethylfumarate & Autoimmune disease \\
\hline Efalizumab & Autoimmune disease (psoriasis) \\
\hline Fingolimod & Autoimmune disease \\
\hline Infliximab & Autoimmune disease \\
\hline Leflunomid & Autoimmune disease \\
\hline Methotrexate & Cancer/autoimmune disease \\
\hline Mycophenolate & Transplantation/autoimmune disease \\
\hline Natalizumab & Autoimmune disease \\
\hline Rituximab & Cancer/autoimmune disease \\
\hline Tacrolimus & Transplantation \\
\hline
\end{tabular}

- Rapid clearance of JCV from CSF

- CD4 count $>200 \mu \mathrm{L}-1$ at onset

- Unfavorable factors:

- Undetectable JCV-specific cellular immune response in blood or CSF

- Mass effect on MRI

- Posterior fossa lesions

- High JC viral load in CSF

- CD4 count $<200 \mu \mathrm{L}-1$ at onset

\subsection{Herpes Simplex Virus (HSV) Encephalitis}

Herpesviruses are

Large, enveloped viruses.

- Contain double-stranded DNA.

- $150 \mathrm{~nm}$ in diameter.

- DNA core surrounded by an icosadeltahedral capsid containing 162 capsomeres.

- Capsid is enclosed by a glycoproteincontaining envelope.

- Encode proteins that manipulate the host cell and immune response.

- DNA replication and capsid assembly occurs in the nucleus.

- Virus is released by

- Exocytosis

- Cell lysis

- Through cell-to-cell bridges

- Cause lytic, persistent, latent, and immortalizing infections

\subsubsection{Clinical Signs and Symptoms}

- Headache

- Neck stiffness

- Drowsiness

- Coma

- Dysphagia

- Hemiparesis

- Focal seizures

\subsubsection{Neuroimaging Findings}

\section{General Imaging Features}

- Involvement of limbic system and temporal lobe

- Often hemorrhages and enhancement

- Often bilateral, but asymmetric

CT Non-Contrast-Enhanced (Fig. 26.11a)

- Normal (early) to mild hypodense, swollen temporal lobes and insula

\section{CT Contrast-Enhanced}

- Patchy enhancement possible

MRI-T2/FLAIR (Fig. 26.11b-d)

- Hyperintense, swollen white matter and cortex of affected areas.

- Hemorrhages may be hypointense. 
Table 26.17 Comparative anatomical, neuropathological, and MRI features of progressive multifocal leukoencephalopathy (PML), progressive multifocal leukoencephalopathy-immune reconstitution inflammatory syndrome (PMLIRIS) and multiple sclerosis (MS) (Bauer et al. 2015) reproduced with kind permission by Springer Nature

\begin{tabular}{|c|c|c|}
\hline PML & PML-IRIS & MS \\
\hline \multicolumn{3}{|l|}{ Anatomical features } \\
\hline $\begin{array}{l}\text { - Lesions mostly reside in cerebral } \\
\text { hemispheres but periventricular lesions } \\
\text { are rare. } \\
\text { - Lesions predominantly affect the deep } \\
\text { and subcortical white matter and can } \\
\text { expand into the cortical gray matter. } \\
\text { - Intracortical lesions are present. } \\
\text { - Spinal cord and optic nerves are } \\
\text { spared. }\end{array}$ & $\begin{array}{l}\text { - Lesion distribution is similar } \\
\text { to PML. }\end{array}$ & $\begin{array}{l}\text { - Lesions can be found in white } \\
\text { and gray matter, but are often } \\
\text { found in a periventricular } \\
\text { position. } \\
\text { - Unlike in PML, lesions can be } \\
\text { found in spinal cord and optic } \\
\text { nerves. }\end{array}$ \\
\hline
\end{tabular}

Neuropathological features

- Demyelinating lesions reveal oligodendrocytes with enlarged nucleus and cytoplasm. The nucleus may show inclusion bodies.

- Oligodendrocytes are mostly found on the border of the lesion.

- Subpial lesions are absent.

- Remyelination is absent.

- Within the demyelinated lesions, large (the so-called bizarre) astrocytes are found.

- Lesions contain low to moderate numbers of T-cells.

- few B-cells

- few plasma cells

- Activated microglial cells and macrophages are present in high numbers.
- Like PML, lesions contain infected cells, especially on the border.

- In small samples (biopsies) however, infected cells may be low in numbers or may be absent.

- Subpial lesions are absent.

- Remyelination is absent.

- Like in PML, lesions contain bizarre astrocytes.

- Lesions contain extremely high numbers of T-cells and B-cells.

- Numbers of microglia and macrophages do not differ with PML.
- Unlike in PML, lesions are perivenous and show finger-like extensions (i.e., Dawson fingers).

- Subpial lesions are present and are specific for MS.

- Lesions can show variable remyelination.

- Lesions can show activated astrocytes and/or astrogliosis.

- Extremely large bizarre astrocytes are absent.

- Lesions contain moderate to high numbers of T-cells.

- Low numbers of B-cell

- Low numbers of plasma cells

- Numbers of (foamy) macrophages do not differ from PML or PML-IRIS.
- Usually larger than $3 \mathrm{~cm}$

- Lesions always start in subcortical regions, probably related to a high blood flow.

- Borders are sharp towards the GM and ill-defined towards the WM.

- In first scans of $28 \%$ of patients, lesions extend in deep GM.

- $23-57 \%$ of (HIV-associated) cases have contrast-enhancing lesions.

- T1 lesions are mostly hypointense.

- Diffusion-weighted images are always hyperintense.

- Punctate T2-hyperintense lesions can be found in the immediate vicinity of the main lesion.
- Usually larger than $3 \mathrm{~cm}$

- Lesions always start in subcortical regions, probably related to a high blood flow.

- Borders are sharp towards the GM and ill-defined towards the WM.

- In first scans of $71 \%$ of patients, lesions extend in deep GM.

- $86 \%$ of PML-IRIS cases have contrast-enhancing lesions.

- T1 lesions may have hyperintense rims.

- Diffusion-weighted images are always hyperintense.

- Punctate T2-hyperintense lesions can be found in the immediate vicinity of the main lesion.
- All MRI features seen in PML and/or PML-IRIS also can be seen in MS.

- However, MS lesions usually are and stay smaller in size than in PML or PML-IRIS.

- Homogeneous or open-ring enhancing lesions are present in MS but not observed in PML. 

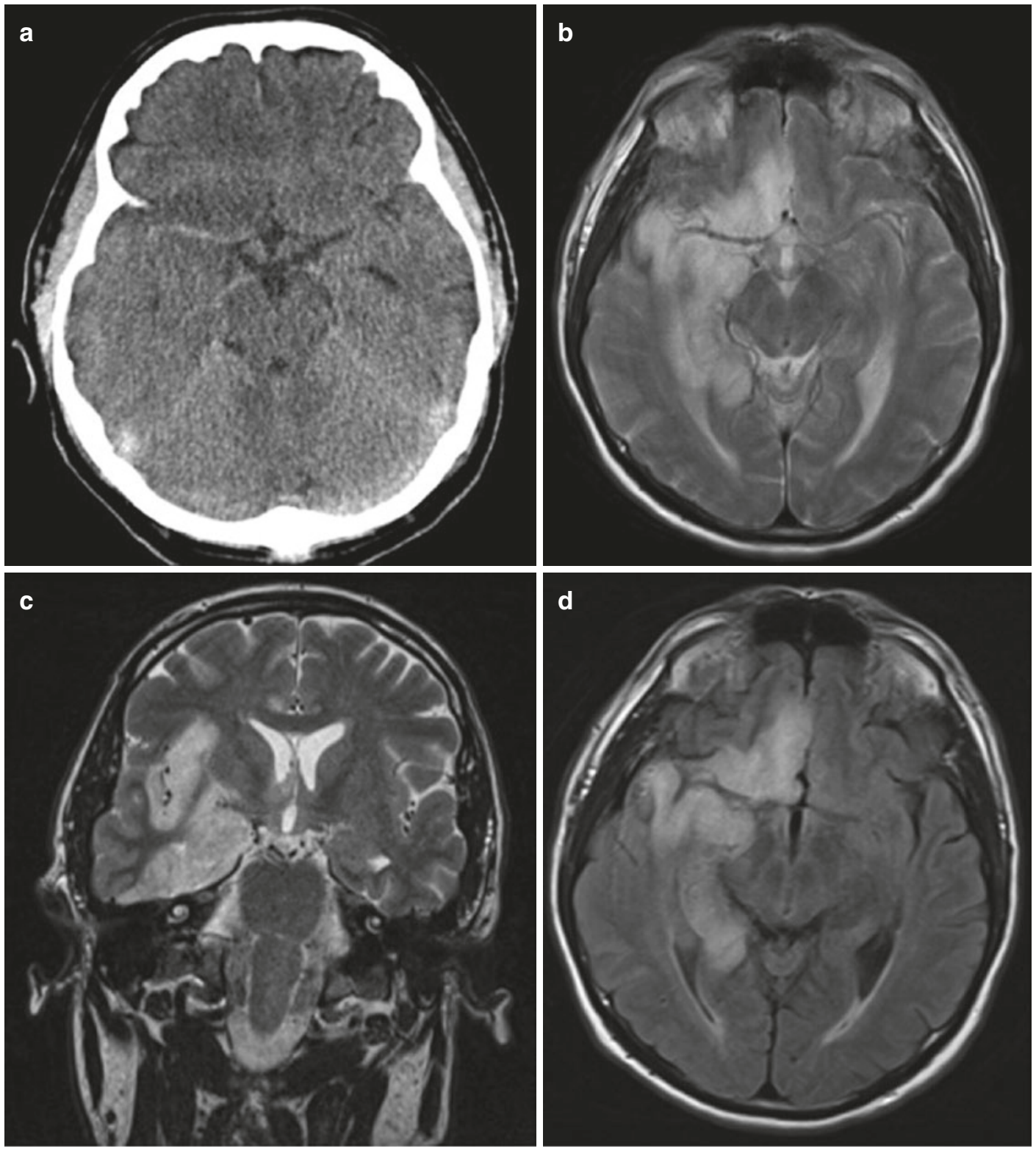

Fig. 26.11 Herpes encephalitis with characteristic involvement of right limbic system, temporal and basal frontal lobe, restricted diffusion and weak enhancement;

CT non-contrast (a), T2 ax/cor (b, c), FLAIR (d), T1 (e), T1 contrast $(\mathbf{f}), \mathrm{DWI}(\mathbf{g}), \mathrm{ADC}(\mathbf{h})$ 

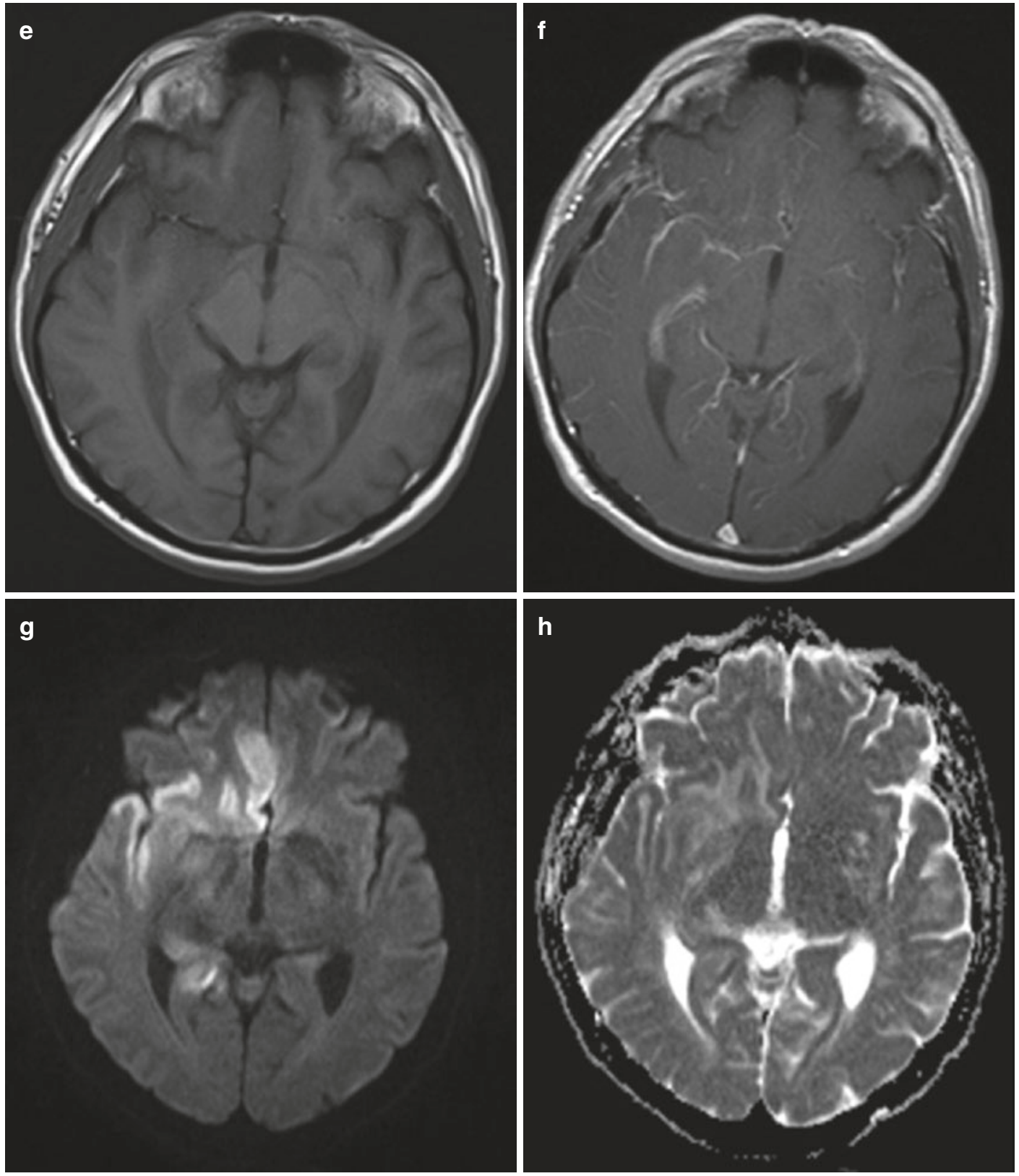

Fig. 26.11 (continued)

MRI-T1 (Fig. 26.11e)

- Hypointense edema

- Loss of gray-white matter differentiation

MRI-T1 Contrast-Enhanced (Fig. 26.11f)

- Diffuse enhancement

\section{MRI-T2 $* /$ SWI}

- Hemorrhages hypointense
MR-Diffusion Imaging (Fig 26.11g)

- Often restricted diffusion

MRI-ADC (Fig. 26.11h)

- Often restricted diffusion

Nuclear Medicine Findings (Fig. 26.12)

- Decreased FDG uptake

- After recovery FDG uptake appears regular 


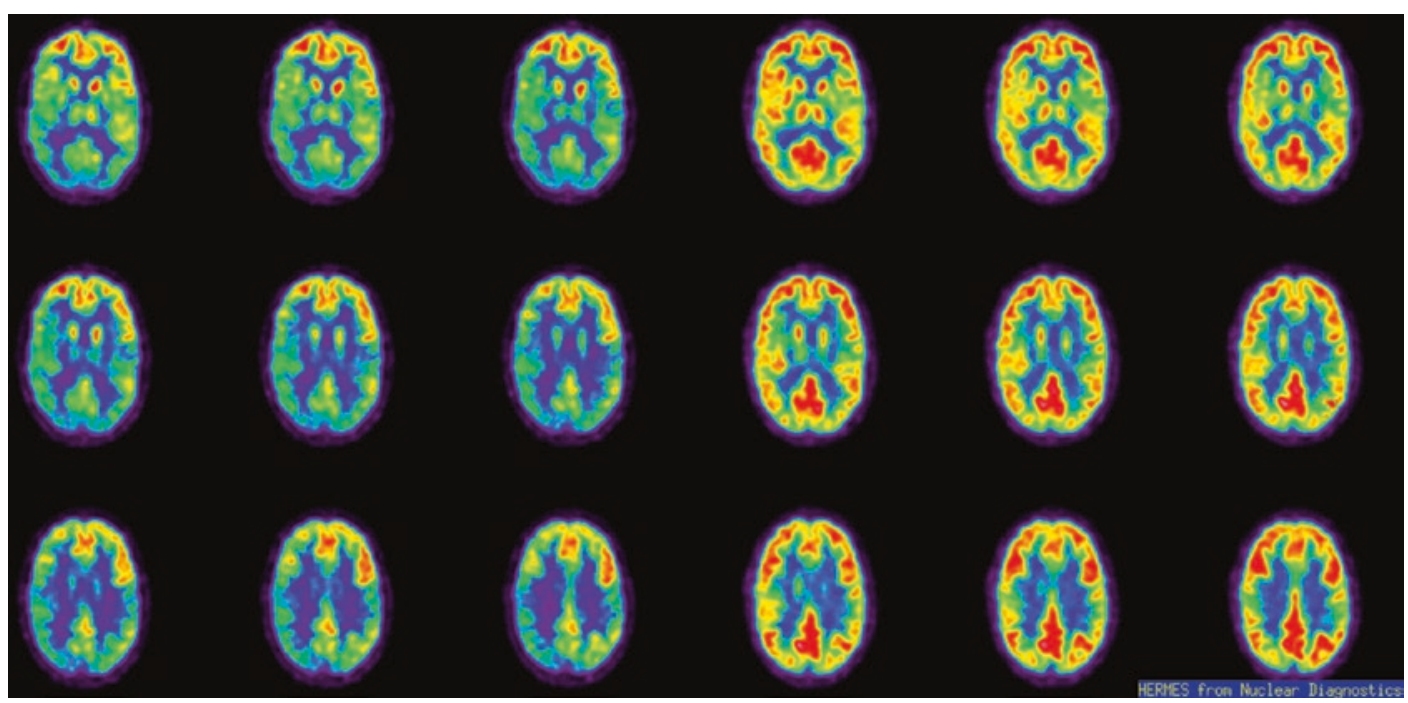

Fig. 26.12 Herpes encephalitis: decreased FDG uptake (left 3 rows) in a patient during the recovery phase of Herpes simplex encephalitis and regular FDG uptake after recovery (right 3 rows)
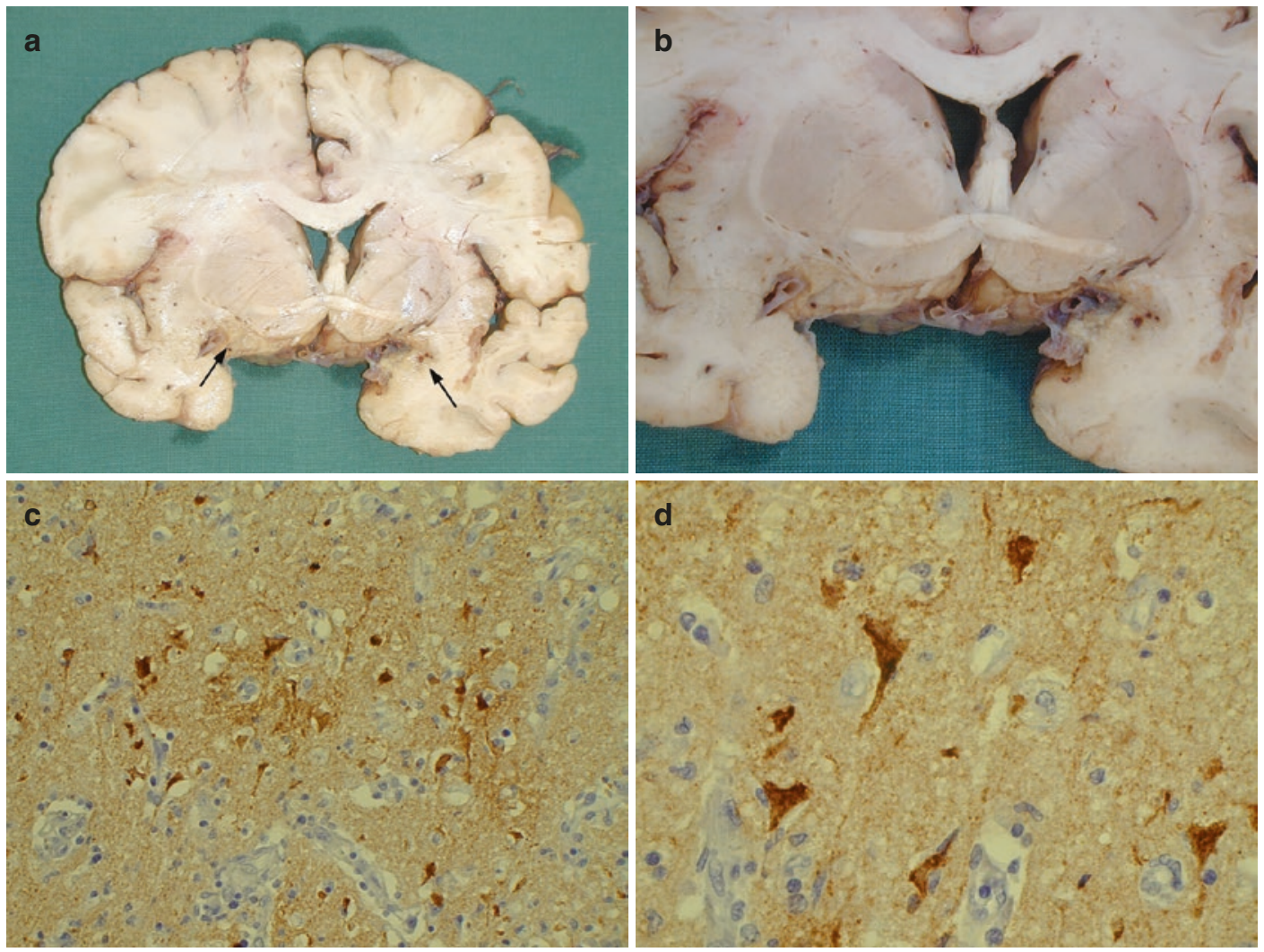

Fig. 26.13 Herpes encephalitis: macroscopically, necrosis is seen in both temporal lobes (arrow) (a, b). The virus is demonstrated by immunohistochemistry mainly in neurons $(\mathbf{c}, \mathbf{d})$ 


\subsubsection{Neuropathology Findings}

Macroscopic Features (Fig. 26.13a, b)

- Congestion

- Hemorrhagic necrosis of the

- Temporal lobe

- Insula

- Cingulate gyrus

- Posterior orbitofrontal cortex

Microscopic Features (Fig. 26.13c, d)

- Acute phase

- parenchymal inflammation

- lymphocytes and macrophages in the leptomeninges

- necrotic cells

- foci of hemorrhages

- perivascular and interstitial infiltrate of lymphocytes

- microglial nodules

- neuronophagia

- Chronic phase

- glial scar tissue

- clusters of lymphocytes

\subsubsection{Molecular Neuropathology}

\section{Pathogenesis}

- Primary mucocutaneous infection

- mucocutaneous border of lips or oropharyngeal mucosa

- Latency in trigeminal ganglion

- by retrograde axonal transport along sensory fibers to the trigeminal ganglion

- further replication

- latent infection (latency-associated transcripts)

- Reactivation of virus

- anterograde transport to the skin or mucose

- development of cold sores

- reactivation

- spontaneously

- mucocutaneous trauma

- ultraviolet irradiation

- emotional stress

- pyrexia

- fluctuations in estrogen and progesterone concentrations

○ immunosuppression

\subsubsection{Treatment and Prognosis}

\section{Outcome}

- Fatal outcome within a few days when untreated

- Treatment

\subsection{Tick-Borne Encephalitis}

Tick-borne encephalitis (TBE) is an infection of the central nervous system (CNS) caused by tick-borne encephalitis virus (TBEV) and transmitted by ticks, with a variety of clinical manifestations (Table 26.18). The incidence of TBE in Europe is increasing due to an extended season of the infection and the enlargement of endemic areas.

Causative agents:

- Togaviridae

- Flaviviridae

- Reoviridae

- Bunyaviridae

TBE is a caused by flavivirus

- Western Europe subtype, tick vector: Ixodes ricinus

- Siberian subtype, tick vector: Ixodes persulcatus

- Far eastern subtype, tick vector: Ixodes persulcatus

\subsubsection{Clinical Signs and Symptoms}

- Meningitis typically manifests with

- High fever

- Headache

- Nausea

- Vomiting

- Encephalitis can be manifested by

- Impaired consciousness

- Somnolence

- Stupor

- Coma

- Myelitis

- Other manifestations comprise

- Personality changes

- Behavioral disorders 
Table 26.18 Viruses causing tick-borne encephalitis

\begin{tabular}{|c|c|c|c|c|}
\hline Virus & $\begin{array}{l}\text { Brain region } \\
\text { affected }\end{array}$ & Mortality & Morbidity & Geographic distribution \\
\hline $\begin{array}{l}\text { Eastern equine } \\
\text { encephalitis }\end{array}$ & & $50-75 \%$ & $\begin{array}{l}90 \% \text { of survivors have persistent } \\
\text { neurologic disability. }\end{array}$ & $\begin{array}{l}\text { - Eastern and Gulf } \\
\text { coast states of the } \\
\text { USA. } \\
\text { - Caribbean } \\
\text { - South America }\end{array}$ \\
\hline $\begin{array}{l}\text { Western equine } \\
\text { encephalitis }\end{array}$ & $\begin{array}{ll}\text { - } & \text { Basal ganglia } \\
\text { - } & \text { Thalamus } \\
\text { - } & \text { Brain stem } \\
\end{array}$ & $<5 \%$ & & $\begin{array}{ll}\text { - } & \text { Western and } \\
\text { Midwestern USA }\end{array}$ \\
\hline $\begin{array}{l}\text { St. Louis } \\
\text { encephalitis }\end{array}$ & $\begin{array}{ll}\text { - } & \text { Midbrain } \\
\text { - } & \text { Thalamus }\end{array}$ & $<5 \%$ & $\begin{array}{l}25 \% \text { of survivors have persistent } \\
\text { neurologic disability. }\end{array}$ & $\begin{array}{ll}\text { - } & \text { The USA } \\
\text { - } & \text { Central America } \\
\text { - } & \text { South America }\end{array}$ \\
\hline $\begin{array}{l}\text { Japanese } \\
\text { encephalitis }\end{array}$ & $\begin{array}{ll}\text { - } & \text { Thalamus } \\
\text { - } & \text { Substantia } \\
& \text { nigra } \\
\text { - } & \text { Brain stem } \\
\text { - } & \text { Spinal cord } \\
\end{array}$ & Up to $50 \%$ & $\begin{array}{l}\text { High percentage of survivors have } \\
\text { persistent neurologic disability. }\end{array}$ & $\begin{array}{l}\text { - } \text { Southeast Asia } \\
\text { - } \text { Bangladesh } \\
\text { - Pakistan }\end{array}$ \\
\hline West Nile virus & $\begin{array}{ll}\text { - } & \text { Thalamus } \\
\text { - } & \text { Substantia } \\
& \text { nigra } \\
\text { - } & \text { Pons } \\
\text { - } & \text { Medulla } \\
& \text { oblongata } \\
\text { - } & \text { Spinal cord } \\
\end{array}$ & $3-15 \%$ & $\begin{array}{l}50-75 \% \text { of survivors have residual } \\
\text { neurologic disability. }\end{array}$ & $\begin{array}{ll}\text { - } & \text { Africa } \\
\text { - } & \text { Eastern Europe } \\
\text { - } & \text { Mest Asia } \\
\text { - } & \text { North America }\end{array}$ \\
\hline $\begin{array}{l}\text { Tick-borne } \\
\text { encephalitis }\end{array}$ & & $1-10 \%$ & $\begin{array}{l}\text { Small percentage develop chronic } \\
\text { encephalitis with intractable epilepsy and } \\
\text { progressive paralysis (Russian spring- } \\
\text { summer encephalitis). }\end{array}$ & \\
\hline
\end{tabular}

- Concentration and cognitive function disturbances

- Tongue fasciculations and tremor of extremities

- Focal or generalized seizures

- Delirium

- Psychosis

\subsubsection{Epidemiology}

\section{Incidence}

- Highly endemic areas ( $\geq 5$ cases/100 000/ year)

\subsubsection{Neuroimaging Findings}

\section{General Imaging Features}

- MRI and CT often normal, rarely lesions in thalamus, cerebellum, or basal ganglia

\section{CT Non-Contrast-Enhanced}

- Usually normal

MRI-T2/FLAIR (Fig. 26.14a, b)

- Lesions hyperintense

MRI-T1 (Fig. 26.14c)

- Lesions hypointense

MRI-T1 Contrast-Enhanced (Fig. 26.14d)

- Meningeal or parenchymal enhancement possible

MR-Diffusion Imaging (Fig. 26.14e)

- Restricted diffusion possible

MRI-ADC (Fig. 26.14f)

- Restricted diffusion possible

Nuclear Medicine Imaging Findings

(Fig. 26.15)

- decreased FDG uptake 

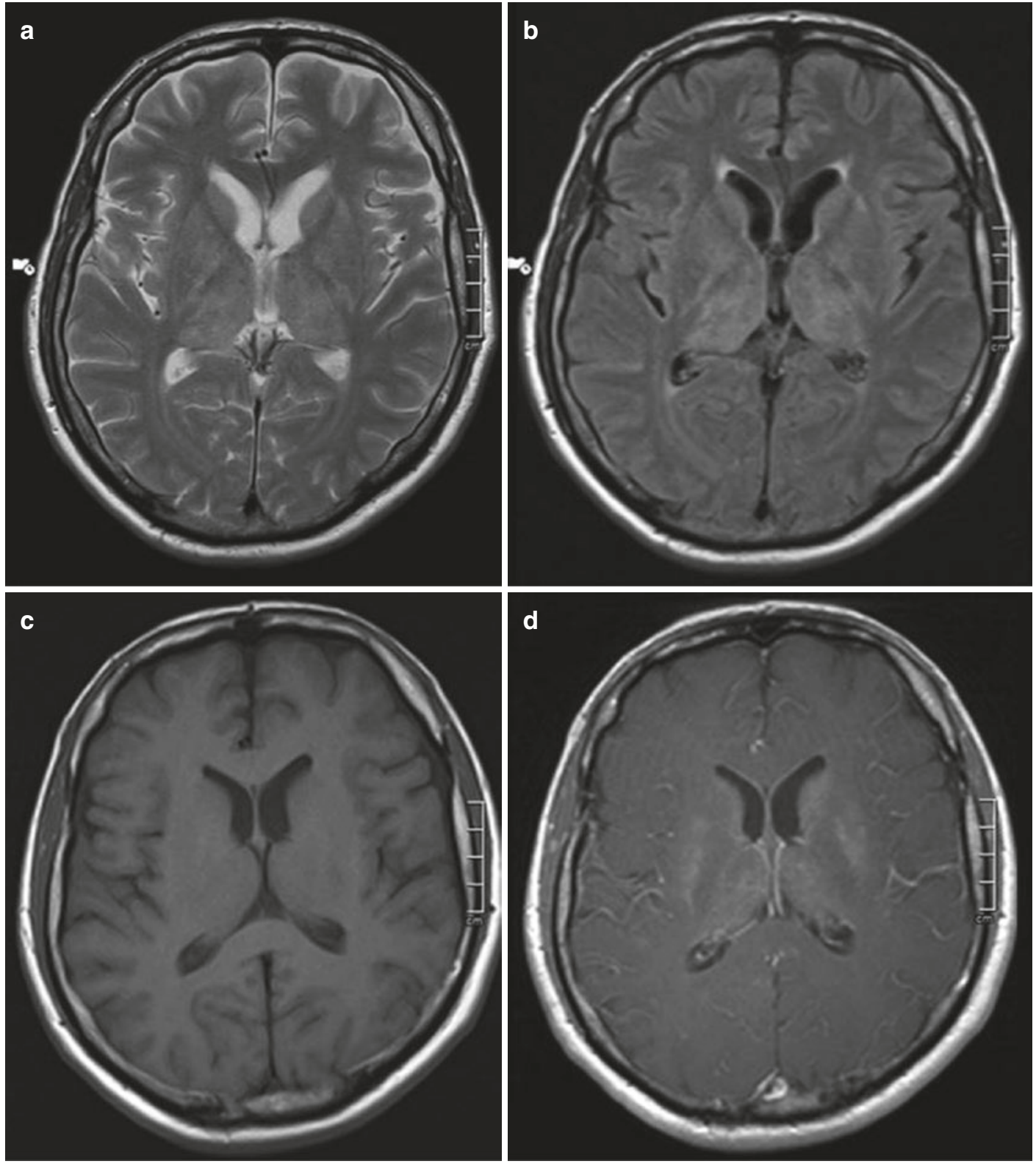

Fig. 26.14 Tick-borne encephalitis with T2-hyperintensity and mild enhancement of thalami and basal ganglia. T2 (a), FLAIR (b), T1 (c), T1 contrast (d), DWI (e), ADC (f) 

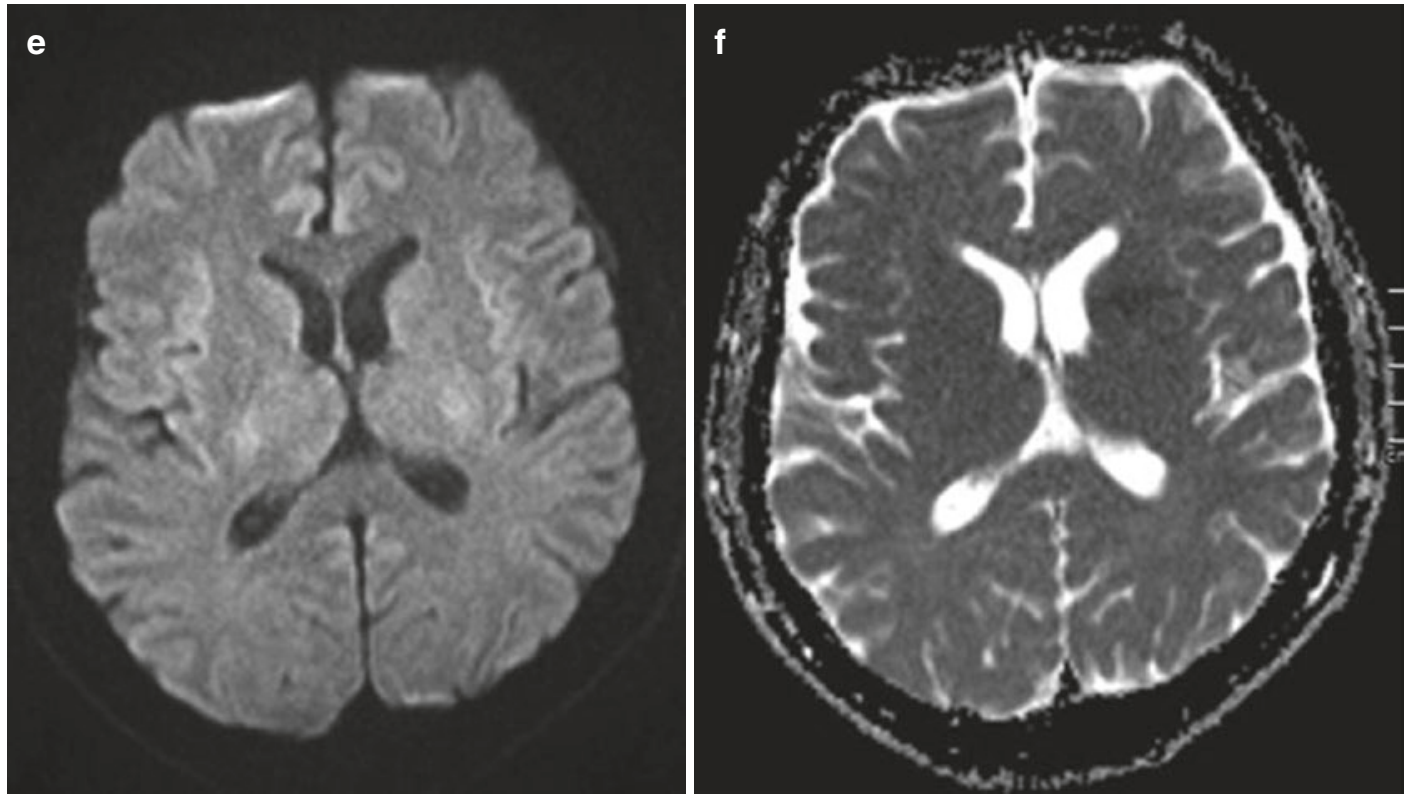

Fig. 26.14 (continued)

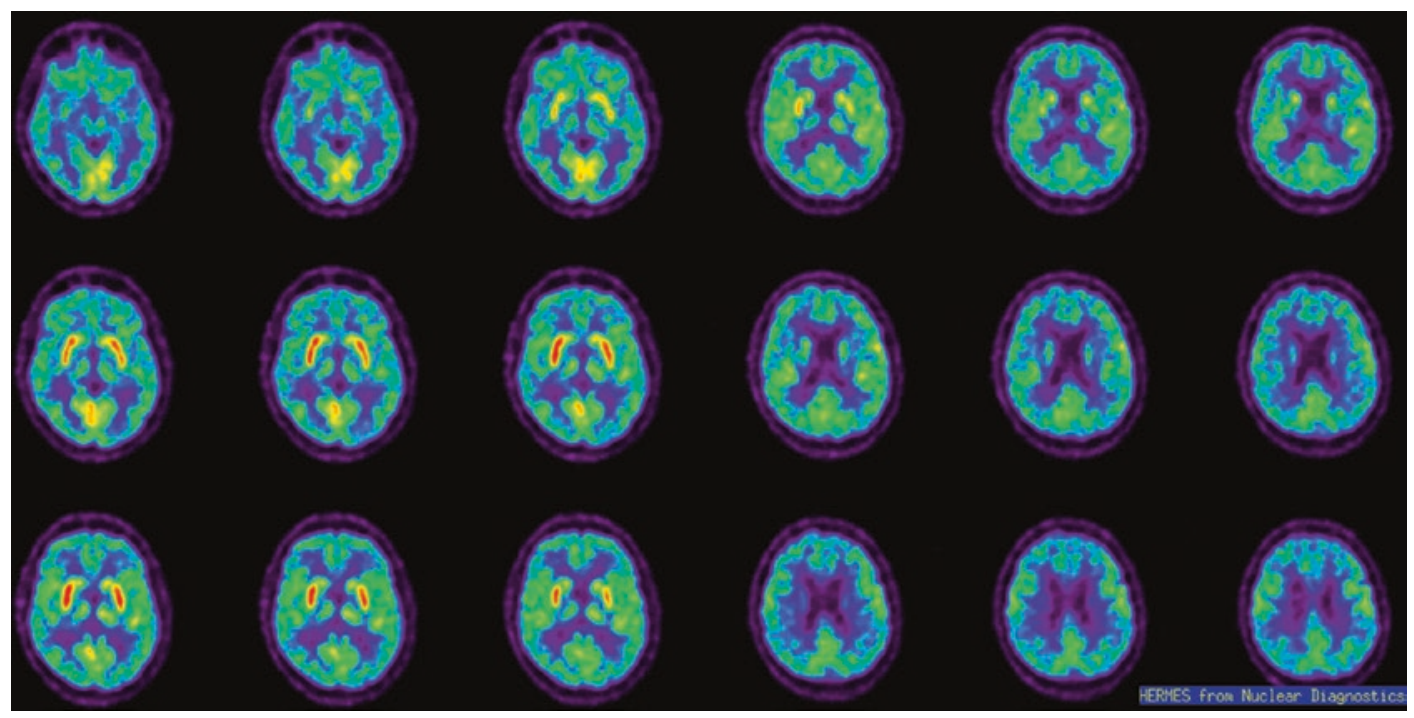

Fig. 26.15 Tick-borne encephalitis: totally decreased FDG uptake in cerebral cortex

\subsubsection{Neuropathology Findings}

Macroscopic Features

- moderate to sever congestion (Fig. 26.15)

- petechial hemorrhages

Microscopic Features (Fig. 26.16a-1)

- lymphocytic infiltrates
- leptomeningeal

- perivascular

- parenchymal

- microglial nodules and macrophages

- focal necrosis of white matter myelinated fibers

- thrombosed small vessels 

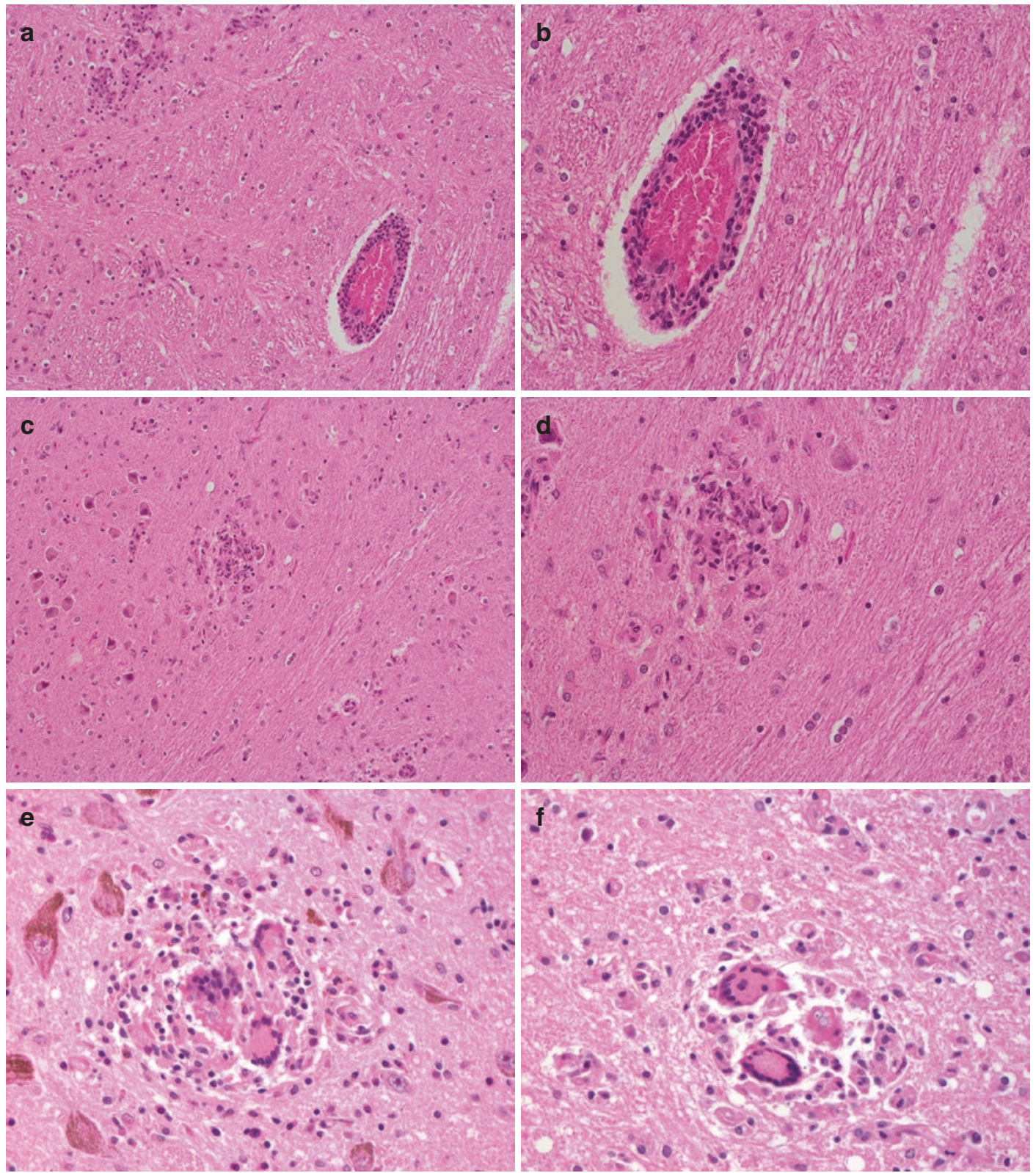

Fig. 26.16 Tick-borne encephalitis: histological examination reveals perivascular lymphocytic infiltrates (a, b) and the presence of gliomesenchymal nodules $(\mathbf{c}, \mathbf{d})$ which may contain multinucleated giant cells $(\mathbf{e}, \mathbf{f})$. The perivascular infiltrates are mainly made up of CD3-

positive T-lymphocytes (g) which are also homing in the surrounding brain tissue (h). Reactive astrogliosis (stain: GFAP) (i, j) and reactive microgliosis (stain: HLA-DRII) $(\mathbf{k}, \mathbf{l})$ might be moderate 

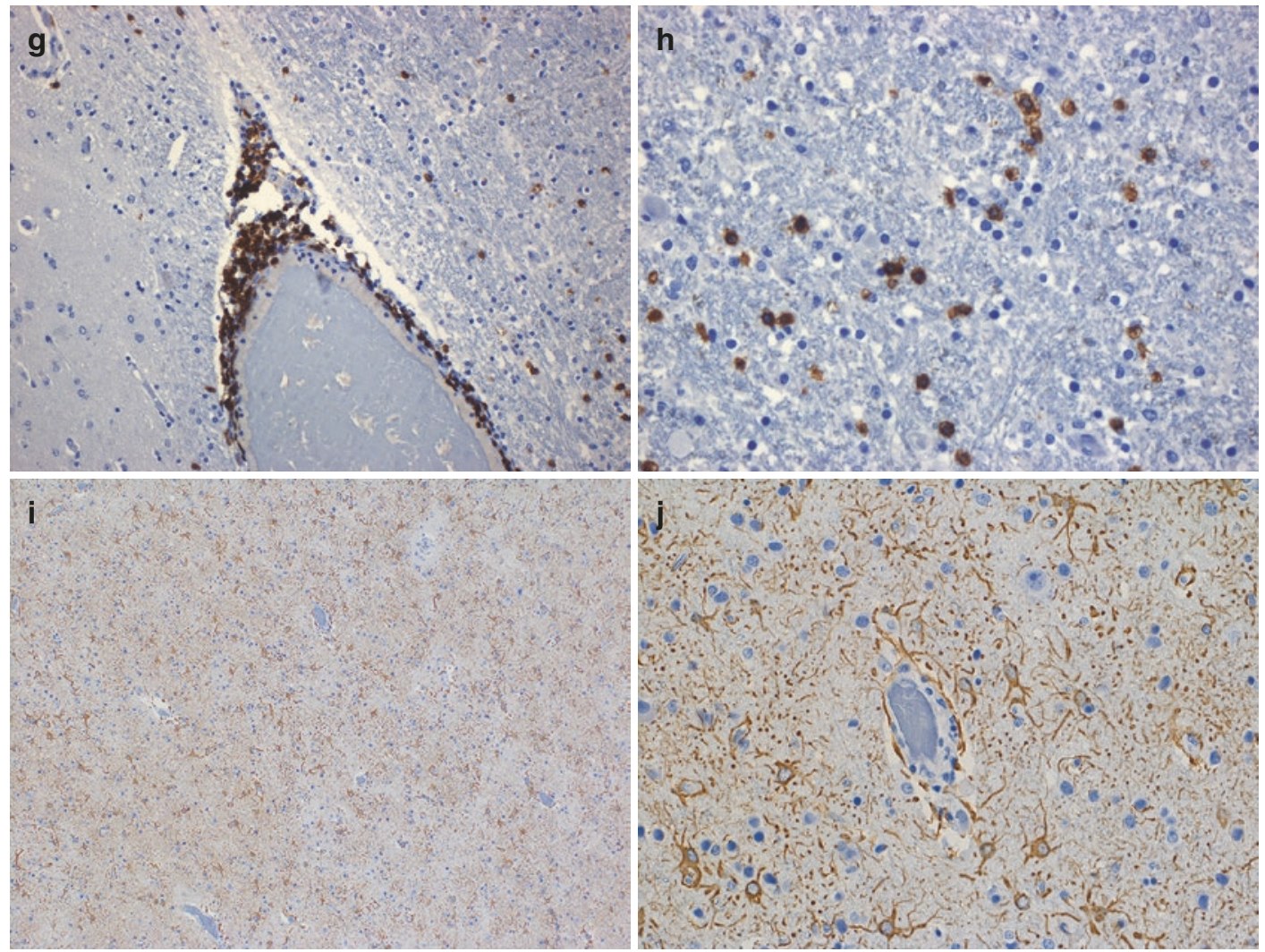

\section{k}

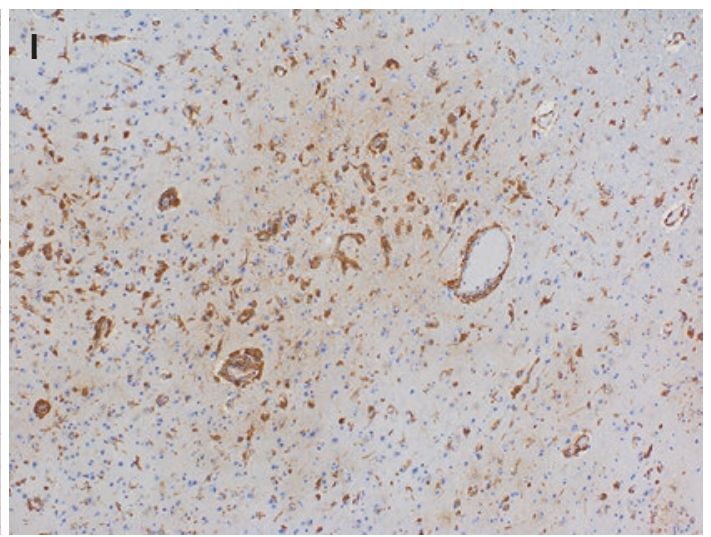

Fig. 26.16 (continued)

\subsubsection{Molecular Neuropathology}

- Virus enters the vector (mosquito or tick) while it is feeding on the blood of an infected host.

- Is transmitted to other hosts in the salivary secretions of the vector.

- Natural hosts are birds or small mammals (rodents).
- Humans are dead-end hosts.

- Virus replicates at the site of host inoculation.

- Spreads to regional lymph nodes and other lymphoreticular tissues.

- Disseminates hematogenously to systemic tissues (CNS). 


\subsubsection{Treatment and Prognosis}

Treatment

- No specific drug therapy

- Corticosteroids

- Tracheal intubation and respiratory support

\section{Outcome}

- Complete restitution to fatal

- Prevention:

- vaccination

\section{Selected References}

Abe H, Mehraein P, Weis S (1996) Degeneration of the cerebellar dentate nucleus and the inferior olivary nuclei in HIV-1-infected brains: a morphometric analysis. Acta Neuropathol 92(2):150-155

Adang L, Berger J (2015) Progressive multifocal leukoencephalopathy. F1000Res:4. https://doi.org/10.12688/ f1000research.7071.1

Aksamit AJ Jr (2012) Progressive multifocal leukoencephalopathy. Continuum (Minneapolis, Minn) 18(6 Infectious Disease):1374-1391. https://doi. org/10.1212/01.CON.0000423852.70641.de

Amicizia D, Domnich A, Panatto D, Lai PL, Cristina ML, Avio U, Gasparini R (2013) Epidemiology of tickborne encephalitis (TBE) in Europe and its prevention by available vaccines. Hum Vaccin Immunother 9(5):1163-1171. https://doi.org/10.4161/hv.23802

Ances BM, Hammoud DA (2014) Neuroimaging of HIV-associated neurocognitive disorders (HAND). Curr Opin HIV AIDS 9(6):545-551. https://doi. org/10.1097/coh.0000000000000112

Andreula C (2004) Cranial viral infections in the adult. Eur Radiol 14(Suppl 3):E132-E144. https://doi. org/10.1007/s00330-003-2040-3

Antinori A, Arendt G, Becker JT, Brew BJ, Byrd DA, Cherner M, Clifford DB, Cinque P, Epstein LG, Goodkin K, Gisslen M, Grant I, Heaton RK, Joseph J, Marder K, Marra CM, McArthur JC, Nunn M, Price RW, Pulliam L, Robertson KR, Sacktor N, Valcour V, Wojna VE (2007) Updated research nosology for HIV-associated neurocognitive disorders. Neurology 69(18):1789-1799. https://doi.org/10.1212/01. WNL.0000287431.88658.8b

Aurelian L (2005) HSV-induced apoptosis in herpes encephalitis. Curr Top Microbiol Immunol 289:79-111

Bale JF Jr (2014) Congenital cytomegalovirus infection. Handb Clin Neurol 123:319-326. https://doi. org/10.1016/b978-0-444-53488-0.00015-8

Baringer JR (2008) Herpes simplex infections of the nervous system. Neurol Clin 26(3):657-674, viii. https:// doi.org/10.1016/j.ncl.2008.03.005
Baskin HJ, Hedlund G (2007) Neuroimaging of herpesvirus infections in children. Pediatr Radiol 37(10):949_ 963. https://doi.org/10.1007/s00247-007-0506-1

Bauer J, Gold R, Adams O, Lassmann H (2015) Progressive multifocal leukoencephalopathy and immune reconstitution inflammatory syndrome (IRIS). Acta Neuropathol 130(6):751-764. https://doi.org/10.1007/ s00401-015-1471-7

Bellizzi A, Anzivino E, Rodio DM, Palamara AT, Nencioni L, Pietropaolo V (2013) New insights on human polyomavirus JC and pathogenesis of progressive multifocal leukoencephalopathy. Clin Dev Immunol 2013:839719. https://doi.org/10.1155/2013/839719

Beltrami S, Gordon J (2014) Immune surveillance and response to JC virus infection and PML. J Neurovirol 20(2):137-149. https://doi.org/10.1007/ s13365-013-0222-6

Berger JR (2011) The clinical features of PML. Cleve Clin J Med 78(Suppl 2):S8-S12. https://doi.org/10.3949/ ccjm.78.s2.03

Berger JR (2014) Progressive multifocal leukoencephalopathy. Handb Clin Neurol 123:357-376. https://doi. org/10.1016/b978-0-444-53488-0.00017-1

Berger JR (2017) Classifying PML risk with disease modifying therapies. Mult Scler Relat Disord 12:59-63. https://doi.org/10.1016/j.msard.2017.01.006

Berger JR, Khalili K (2011) The pathogenesis of progressive multifocal leukoencephalopathy. Discov Med 12(67):495-503

Berger JR, Aksamit AJ, Clifford DB, Davis L, Koralnik IJ, Sejvar JJ, Bartt R, Major EO, Nath A (2013) PML diagnostic criteria: consensus statement from the AAN Neuroinfectious Disease Section. Neurology 80(15):1430-1438. https://doi.org/10.1212/ WNL.0b013e31828c2fa1

Birkmann A, Zimmermann H (2016) HSV antiviralscurrent and future treatment options. Curr Opin Virol 18:9-13. https://doi.org/10.1016/j.coviro.2016.01.013

Bloom DC (2004) HSV LAT and neuronal survival. Int Rev Immunol 23(1-2):187-198

Bradshaw MJ, Venkatesan A (2016) Herpes simplex virus-1 encephalitis in adults: pathophysiology, diagnosis, and management. Neurotherapeutics 13(3):493508. https://doi.org/10.1007/s13311-016-0433-7

Brown JC (2017) Herpes simplex virus latency: the DNA repair-centered pathway. Adv Virol 2017:7028194. https://doi.org/10.1155/2017/7028194

Buttner A, Mehraein P, Weis S (1996) Vascular changes in the cerebral cortex in HIV-1 infection. II An immunohistochemical and lectinhistochemical investigation. Acta Neuropathol 92(1):35-41

Cantey JB, Sanchez PJ (2013) Neonatal herpes simplex virus infections: past progress and future challenges. Pediatr Infect Dis J 32(11):1205-1207. https://doi. org/10.1097/INF.0b013e3182a1915e

Carletti T, Zakaria MK, Marcello A (2017) The host cell response to tick-borne encephalitis virus. Biochem Biophys Res Commun 492(4):533-540. https://doi. org/10.1016/j.bbrc.2017.02.006

Carroll A, Brew B (2017) HIV-associated neurocognitive disorders: recent advances in pathogenesis, bio- 
markers, and treatment. F1000Res 6:312. https://doi. org/10.12688/f1000research.10651.1

Chahroudi A, Silvestri G (2012) IRIS: the unfortunate rainbow of HIV. Blood 119(13):2971-2972. https:// doi.org/10.1182/blood-2012-01-403683

Chen MF, Gill AJ, Kolson DL (2014) Neuropathogenesis of HIV-associated neurocognitive disorders: roles for immune activation, HIV blipping and viral tropism. Curr Opin HIV AIDS 9(6):559-564. https://doi. org/10.1097/coh.0000000000000105

Ciardi A, Sinclair E, Scaravilli F, Harcourt-Webster NJ, Lucas S (1990) The involvement of the cerebral cortex in human immunodeficiency virus encephalopathy: a morphological and immunohistochemical study. Acta Neuropathol 81(1):51-59

Cinque P, Koralnik IJ, Gerevini S, Miro JM, Price RW (2009) Progressive multifocal leukoencephalopathy in HIV-1 infection. Lancet Infect Dis 9(10):625-636. https://doi.org/10.1016/s1473-3099(09)70226-9

Clifford DB, Ances BM (2013) HIV-associated neurocognitive disorder. Lancet Infect Dis 13(11):976-986. https://doi.org/10.1016/s1473-3099(13)70269-x

Corey L, Wald A (2009) Maternal and neonatal herpes simplex virus infections. N Engl J Med 361(14):13761385. https://doi.org/10.1056/NEJMra0807633

Del Valle L, Pina-Oviedo S (2006) HIV disorders of the brain: pathology and pathogenesis. Front Biosci 11:718-732

Desai DV, Kulkarni SS (2015) Herpes simplex virus: the interplay between HSV, host, and HIV-1. Viral Immunol 28(10):546-555. https://doi.org/10.1089/ vim.2015.0012

Descamps M, Hyare H, Stebbing J, Winston A (2008) Magnetic resonance imaging and spectroscopy of the brain in HIV disease. J HIV Ther 13(3):55-58

Dorrbecker B, Dobler G, Spiegel M, Hufert FT (2010) Tickborne encephalitis virus and the immune response of the mammalian host. Travel Med Infect Dis 8(4):213222. https://doi.org/10.1016/j.tmaid.2010.05.010

Eggers C, Arendt G, Hahn K, Husstedt IW, Maschke M, Neuen-Jacob E, Obermann M, Rosenkranz T, Schielke E, Straube E (2017) HIV-1-associated neurocognitive disorder: epidemiology, pathogenesis, diagnosis, and treatment. J Neurol 264(8):1715-1727. https://doi. org/10.1007/s00415-017-8503-2

Ellis R, Langford D, Masliah E (2007) HIV and antiretroviral therapy in the brain: neuronal injury and repair. Nat Rev Neurosci 8(1):33-44. https://doi.org/10.1038/ nrn2040

Esiri MM, Morris CS, Millard PR (1991) Fate of oligodendrocytes in HIV-1 infection. AIDS (London, England) 5(9):1081-1088

Everall I, Luthert P, Lantos P (1993) A review of neuronal damage in human immunodeficiency virus infection: its assessment, possible mechanism and relationship to dementia. J Neuropathol Exp Neurol 52(6):561-566

Ferenczy MW, Marshall LJ, Nelson CD, Atwood WJ, Nath A, Khalili K, Major EO (2012) Molecular biology, epidemiology, and pathogenesis of progressive multifocal leukoencephalopathy, the JC virus-induced demyelin- ating disease of the human brain. Clin Microbiol Rev 25(3):471-506. https://doi.org/10.1128/cmr.05031-11

Force WGotAAoNAT (1991) Nomenclature and research case definitions for neurologic manifestations of human immunodeficiency virus-type 1 (HIV-1) infection. Report of a Working Group of the American Academy of Neurology AIDS Task Force. Neurology 41(6):778-785

Fournier A, Martin-Blondel G, Lechapt-Zalcman E, Dina J, Kazemi A, Verdon R, Mortier E, de La Blanchardiere A (2017) Immune reconstitution inflammatory syndrome unmasking or worsening AIDS-related progressive multifocal leukoencephalopathy: a literature review. Front Immunol 8:577. https://doi.org/10.3389/ fimmu.2017.00577

Garden GA (2002) Microglia in human immunodeficiency virus-associated neurodegeneration. Glia 40(2):240-251. https://doi.org/10.1002/glia.10155

Gartner S (2000) HIV infection and dementia. Science (New York, NY) 287(5453):602-604

Gelman BB, Guinto FC Jr (1992) Morphometry, histopathology, and tomography of cerebral atrophy in the acquired immunodeficiency syndrome. Ann Neurol 32(1):31-40. https://doi.org/10.1002/ana.410320107

Gendelman HE, Lipton SA, Tardieu M, Bukrinsky MI, Nottet HS (1994) The neuropathogenesis of HIV-1 infection. J Leukoc Biol 56(3):389-398

Gheuens S, Wuthrich C, Koralnik IJ (2013) Progressive multifocal leukoencephalopathy: why gray and white matter. Annu Rev Pathol 8:189-215. https://doi. org/10.1146/annurev-pathol-020712-164018

Gilden DH (2008) Brain imaging abnormalities in CNS virus infections. Neurology 70(1):84. https://doi. org/10.1212/01.wnl.0000286937.09760.e4

Gnann JW Jr, Whitley RJ (2017) Herpes simplex encephalitis: an update. Curr Infect Dis Rep 19(3):13. https:// doi.org/10.1007/s11908-017-0568-7

Gougeon ML (2017) Alarmins and central nervous system inflammation in $\mathrm{HIV}$-associated neurological disorders. J Intern Med 281(5):433-447. https://doi. org/10.1111/joim. 12570

Gray F, Gherardi R, Scaravilli F (1988) The neuropathology of the acquired immune deficiency syndrome (AIDS). A review. Brain J Neurol 111(Pt 2):245-266

Gray F, Lescs MC, Keohane C, Paraire F, Marc B, Durigon M, Gherardi R (1992) Early brain changes in HIV infection: neuropathological study of $11 \mathrm{HIV}$ seropositive, non-AIDS cases. J Neuropathol Exp Neurol 51(2):177-185

Gray F, Chretien F, Vallat-Decouvelaere AV, Scaravilli F (2003) The changing pattern of HIV neuropathology in the HAART era. J Neuropathol Exp Neurol 62(5):429-440

Grosche L, Kummer M, Steinkasserer A (2017) What goes around, comes around-HSV-1 replication in monocyte-derived dendritic cells. Front Microbiol 8:2149. https://doi.org/10.3389/fmicb.2017.02149

Hartman EA, Huang D (2008) Update on PML: lessons from the HIV uninfected and new insights in pathogenesis and treatment. Curr HIV/AIDS Rep 5(3):112-119 
Holt JL, Kraft-Terry SD, Chang L (2012) Neuroimaging studies of the aging HIV-1-infected brain. J Neurovirol 18(4):291-302. https://doi.org/10.1007/ s13365-012-0114-1

Honce JM, Nagae L, Nyberg E (2015) Neuroimaging of natalizumab complications in multiple sclerosis: PML and other associated entities. Mult Scler Int 2015:809252. https://doi.org/10.1155/2015/809252

Hong S, Banks WA (2015) Role of the immune system in HIV-associated neuroinflammation and neurocognitive implications. Brain Behav Immun 45:1-12. https://doi.org/10.1016/j.bbi.2014.10.008

Horger M, Beck R, Fenchel M, Ernemann U, Nagele T, Brodoefel H, Heckl S (2012a) Imaging findings in tick-borne encephalitis with differential diagnostic considerations. AJR Am J Roentgenol 199(2):420427. https://doi.org/10.2214/ajr.11.7911

Horger M, Beschorner R, Beck R, Nagele T, Schulze M, Ernemann U, Heckl S (2012b) Common and uncommon imaging findings in progressive multifocal leukoencephalopathy (PML) with differential diagnostic considerations. Clin Neurol Neurosurg 114(8):11231130. https://doi.org/10.1016/j.clineuro.2012.06.018

Hu XT (2016) HIV-1 tat-mediated calcium dysregulation and neuronal dysfunction in vulnerable brain regions. Curr Drug Targets 17(1):4-14

Itoh K, Mehraein P, Weis S (2000) Neuronal damage of the substantia nigra in HIV-1 infected brains. Acta Neuropathol 99(4):376-384

Jelcic I, Jelcic I, Faigle W, Sospedra M, Martin R (2015) Immunology of progressive multifocal leukoencephalopathy. J Neurovirol 21(6):614-622. https://doi. org/10.1007/s13365-014-0294-y

Jellinger KA, Setinek U, Drlicek M, Bohm G, Steurer A, Lintner F (2000) Neuropathology and general autopsy findings in AIDS during the last 15 years. Acta Neuropathol 100(2):213-220

Jiang YC, Feng H, Lin YC, Guo XR (2016) New strategies against drug resistance to herpes simplex virus. Int $\mathrm{J}$ Oral Sci 8(1):1-6. https://doi.org/10.1038/ijos.2016.3

Joseph J, Colosi DA, Rao VR (2016) HIV-1 induced CNS dysfunction: current overview and research priorities. Curr HIV Res 14(5):389-399

Kaiser R (2008) Tick-borne encephalitis. Infect Dis Clin N Am 22(3):561-575, x. https://doi.org/10.1016/j. idc.2008.03.013

Kastrup O, Wanke I, Maschke M (2005) Neuroimaging of infections. NeuroRx 2(2):324-332. https://doi. org/10.1602/neurorx.2.2.324

Kastrup O, Wanke I, Maschke M (2008) Neuroimaging of infections of the central nervous system. Semin Neurol 28(4):511-522. https://doi.org/10.105 5/s-0028-1083688

Kaul M, Garden GA, Lipton SA (2001) Pathways to neuronal injury and apoptosis in HIV-associated dementia. Nature 410(6831):988-994. https://doi. org/10.1038/35073667

Ketzler S, Weis S, Haug H, Budka H (1990) Loss of neurons in the frontal cortex in AIDS brains. Acta Neuropathol 80(1):92-94
Kolson DL (2002) Neuropathogenesis of central nervous system HIV-1 infection. Clin Lab Med 22(3):703-717

Kolson D (2017) Neurologic complications in persons with HIV infection in the era of antiretroviral therapy. Top Antivir Med 25(3):97-101

Kozlowski PB, Sher JH, Rao C, Anzil PA, Wrzolek MA, Sharer L, Cho ES, Dickson DW, Weidenheim KM, Llena JF et al (1993) Central nervous system in pediatric AIDS. Results from Neuropathologic Pediatric AIDS Registry. Ann N Y Acad Sci 693:295-296

Lamers SL, Rose R, Ndhlovu LC, Nolan DJ, Salemi M, Maidji E, Stoddart CA, McGrath MS (2016) The meningeal lymphatic system: a route for HIV brain migration? J Neurovirol 22(3):275-281. https://doi. org/10.1007/s13365-015-0399-y

Langford TD, Letendre SL, Larrea GJ, Masliah E (2003) Changing patterns in the neuropathogenesis of HIV during the HAART era. Brain Pathol (Zurich, Switzerland) 13(2):195-210

Laothamatas J, Hemachudha T, Mitrabhakdi E, Wannakrairot P, Tulayadaechanont S (2003) MR imaging in human rabies. AJNR Am J Neuroradiol 24(6):1102-1109

Laothamatas J, Sungkarat W, Hemachudha T (2011) Neuroimaging in rabies. Adv Virus Res 79:309327. https://doi.org/10.1016/b978-0-12-387040-7. 00014-7

Le LT, Spudich SS (2016) HIV-associated neurologic disorders and central nervous system opportunistic infections in HIV. Semin Neurol 36(4):373-381. https:// doi.org/10.1055/s-0036-1585454

Levine AJ, Panos SE, Horvath S (2014) Genetic, transcriptomic, and epigenetic studies of HIV-associated neurocognitive disorder. $\mathrm{J}$ Acquir Immune Defic Syndr 65(4):481-503. https://doi.org/10.1097/ qai.0000000000000069

Lindquist L (2014) Tick-borne encephalitis. Handb Clin Neurol 123:531-559. https://doi.org/10.1016/ b978-0-444-53488-0.00025-0

Liner KJ 2nd, Ro MJ, Robertson KR (2010) HIV, antiretroviral therapies, and the brain. Curr HIV/ AIDS Rep 7(2):85-91. https://doi.org/10.1007/ s11904-010-0042-8

Lipton SA (1991) HIV-related neurotoxicity. Brain Pathol (Zurich, Switzerland) 1(3):193-199

Liu H, Xu E, Liu J, Xiong H (2016) Oligodendrocyte injury and pathogenesis of HIV-1-associated neurocognitive disorders. Brain Sci 6(3):E23. https://doi. org/10.3390/brainsci6030023

Lopez-Labrador FX, Berenguer M, Navarro D (2015) Overcoming drug resistance in $\mathrm{HSV}, \mathrm{CMV}, \mathrm{HBV}$ and HCV infection. Future Microbiol 10(11):1759-1766. https://doi.org/10.2217/fmb.15.74

Louboutin JP, Strayer DS (2012) Blood-brain barrier abnormalities caused by HIV-1 gp120: mechanistic and therapeutic implications. Sci J 2012:482575. https://doi.org/10.1100/2012/482575

Malik S, Eugenin EA (2016) Mechanisms of HIV neuropathogenesis: role of cellular communication systems. Curr HIV Res 14(5):400-411 
Marban C, Forouzanfar F, Ait-Ammar A, Fahmi F, El Mekdad H, Daouad F, Rohr O, Schwartz C (2016) Targeting the brain reservoirs: toward an HIV cure. Front Immunol 7:397. https://doi.org/10.3389/ fimmu.2016.00397

Maschke M, Kastrup O, Forsting M, Diener HC (2004) Update on neuroimaging in infectious central nervous system disease. Curr Opin Neurol 17(4):475-480

Masliah E, Achim CL, Ge N, DeTeresa R, Terry RD, Wiley CA (1992a) Spectrum of human immunodeficiency virus-associated neocortical damage. Ann Neurol 32(3):321-329. https://doi.org/10.1002/ ana.410320304

Masliah E, Ge N, Morey M, DeTeresa R, Terry RD, Wiley CA (1992b) Cortical dendritic pathology in human immunodeficiency virus encephalitis. Lab Invest 66(3):285-291

McCarthy M, Nath A (2010) Neurologic consequences of the immune reconstitution inflammatory syndrome (IRIS). Curr Neurol Neurosci Rep 10(6):467-475. https://doi.org/10.1007/s11910-010-0138-y

McRae M (2016) HIV and viral protein effects on the blood brain barrier. Tissue Barriers 4(1):e1143543. https://doi.org/10.1080/21688370.2016.1143543

Meeker RB, Asahchop E, Power C (2014) The brain and HAART: collaborative and combative connections. Curr Opin HIV AIDS 9(6):579-584. https://doi. org/10.1097/coh.0000000000000110

Menendez CM, Carr DJJ (2017) Defining nervous system susceptibility during acute and latent herpes simplex virus-1 infection. J Neuroimmunol 308:43-49. https:// doi.org/10.1016/j.jneuroim.2017.02.020

Molloy ES, Calabrese CM, Calabrese LH (2017) The risk of progressive multifocal leukoencephalopathy in the biologic era: prevention and management. Rheum Dis Clin N Am 43(1):95-109. https://doi.org/10.1016/j. rdc.2016.09.009

Monaco MC, Major EO (2015) Immune system involvement in the pathogenesis of JC virus induced PML: what is learned from studies of patients with underlying diseases and therapies as risk factors. Front Immunol 6:159. https://doi.org/10.3389/fimmu.2015.00159

Navia BA, Cho ES, Petito CK, Price RW (1986a) The AIDS dementia complex: II. Neuropathology. Ann Neurol 19(6):525-535. https://doi.org/10.1002/ ana.410190603

Navia BA, Jordan BD, Price RW (1986b) The AIDS dementia complex: I. Clinical features. Ann Neurol 19(6):517-524. https://doi.org/10.1002/ ana.410190602

Nelson AM, Manabe YC, Lucas SB (2017) Immune reconstitution inflammatory syndrome (IRIS): what pathologists should know. Semin Diagn Pathol 34(4):340-351. https://doi.org/10.1053/j. semdp.2017.04.010

Netravathi M, Mahadevan A, Satishchandra P, Shobha N, Mailankody P, Kandavel T, Jitender S, Anantaram G, Nagarathna S, Govekar S, Ravikumar BV, Ravi V, Shankar SK (2013) Progressive multifocal leukoencephalopathy (PML) associated with HIV Clade C-is not uncommon. J Neurovirol 19(3):198-208. https:// doi.org/10.1007/s13365-013-0168-8

Nicoll MP, Proenca JT, Efstathiou S (2012) The molecular basis of herpes simplex virus latency. FEMS Microbiol Rev 36(3):684-705. https://doi. org/10.1111/j.1574-6976.2011.00320.x

Nightingale S, Winston A, Letendre S, Michael BD, McArthur JC, Khoo S, Solomon T (2014) Controversies in HIV-associated neurocognitive disorders. Lancet Neurol 13(11):1139-1151. https://doi. org/10.1016/s1474-4422(14)70137-1

Oster S, Christoffersen P, Gundersen HJ, Nielsen JO, Pakkenberg B, Pedersen C (1993) Cerebral atrophy in AIDS: a stereological study. Acta Neuropathol 85(6):617-622

Pavlovic D, Patera AC, Nyberg F, Gerber M, Liu M (2015) Progressive multifocal leukoencephalopathy: current treatment options and future perspectives. Ther Adv Neurol Disord 8(6):255-273. https://doi. org/10.1177/1756285615602832

Persidsky Y, Gendelman HE (2003) Mononuclear phagocyte immunity and the neuropathogenesis of HIV-1 infection. J Leukoc Biol 74(5):691-701. https://doi. org/10.1189/jlb.0503205

Pires de Mello CP, Bloom DC, Paixao IC (2016) Herpes simplex virus type-1: replication, latency, reactivation and its antiviral targets. Antivir Ther 21(4):277-286. https://doi.org/10.3851/imp3018

Rao VR, Ruiz AP, Prasad VR (2014) Viral and cellular factors underlying neuropathogenesis in HIV associated neurocognitive disorders (HAND). AIDS Res Ther 11:13. https://doi.org/10.1186/1742-6405-11-13

Reyes MG, Faraldi F, Senseng CS, Flowers C, Fariello R (1991) Nigral degeneration in acquired immune deficiency syndrome (AIDS). Acta Neuropathol 82(1):39-44

Rocha AJ, Littig IA, Nunes RH, Tilbery CP (2013) Central nervous system infectious diseases mimicking multiple sclerosis: recognizing distinguishable features using MRI. Arq Neuropsiquiatr 71(9b):738-746. https://doi.org/10.1590/0004-282x20130162

Roizman B, Whitley RJ (2013) An inquiry into the molecular basis of HSV latency and reactivation. Annu Rev Microbiol 67:355-374. https://doi.org/10.1146/ annurev-micro-092412-155654

Rozenberg F, Deback C, Agut H (2011) Herpes simplex encephalitis: from virus to therapy. Infect Disord Drug Targets 11(3):235-250

Ru W, Tang SJ (2017) HIV-associated synaptic degeneration. Mol Brain 10(1):40. https://doi.org/10.1186/ s13041-017-0321-z

Rumboldt Z (2008) Imaging of topographic viral CNS infections. Neuroimaging Clin N Am 18(1):85-92; viii. https://doi.org/10.1016/j.nic.2007.12.006

Ruzek D, Dobler G, Donoso Mantke O (2010) Tick-borne encephalitis: pathogenesis and clinical implications. Travel Med Infect Dis 8(4):223-232. https://doi. org/10.1016/j.tmaid.2010.06.004

Ryan LA, Cotter RL, Zink WE 2nd, Gendelman HE, Zheng J (2002) Macrophages, chemokines and neu- 
ronal injury in HIV-1-associated dementia. Cell Mol Biol (Noisy-le-Grand) 48(2):137-150

Sabri F, Titanji K, De Milito A, Chiodi F (2003) Astrocyte activation and apoptosis: their roles in the neuropathology of HIV infection. Brain Pathol (Zurich, Switzerland) 13(1):84-94

Sahraian MA, Radue EW, Eshaghi A, Besliu S, Minagar A (2012) Progressive multifocal leukoencephalopathy: a review of the neuroimaging features and differential diagnosis. Eur J Neurol 19(8):1060-1069. https://doi. org/10.1111/j.1468-1331.2011.03597.x

Sanchez AB, Kaul M (2017) Neuronal stress and injury caused by HIV-1, cART and drug abuse: converging contributions to HAND. Brain Sci 7(3):E25. https:// doi.org/10.3390/brainsci7030025

Saylor D, Dickens AM, Sacktor N, Haughey N, Slusher B, Pletnikov M, Mankowski JL, Brown A, Volsky DJ, McArthur JC (2016) HIV-associated neurocognitive disorder-pathogenesis and prospects for treatment. Nat Rev Neurol 12(4):234-248. https://doi. org/10.1038/nrneurol.2016.27

Schwab N, Schneider-Hohendorf T, Melzer N, Cutter G, Wiendl H (2017) Natalizumab-associated PML: challenges with incidence, resulting risk, and risk stratification. Neurology 88(12):1197-1205. https:// doi.org/10.1212/wnl.0000000000003739

Senocak E, Oguz KK, Ozgen B, Kurne A, Ozkaya G, Unal S, Cila A (2010) Imaging features of CNS involvement in AIDS. Diagn Interv Radiol (Ankara, Turkey) 16(3):193-200. https://doi.org/10.4261/13053825.dir.2182-08.1

Shah R, Bag AK, Chapman PR, Cure JK (2010) Imaging manifestations of progressive multifocal leukoencephalopathy. Clin Radiol 65(6):431-439. https://doi. org/10.1016/j.crad.2010.03.001

Singh SK (2016) Overview on the tricks of HIV tat to hit the blood brain barrier. Curr HIV Res 14(5):382-388

Smit R, Postma MJ (2015) Review of tick-borne encephalitis and vaccines: clinical and economical aspects. Expert Rev Vaccines 14(5):737-747. https://doi.org/1 $0.1586 / 14760584.2015 .985661$

Sotrel A, Dal Canto MC (2000) HIV-1 and its causal relationship to immunosuppression and nervous system disease in AIDS: a review. Hum Pathol 31(10):12741298. https://doi.org/10.1053/hupa.2000.19293

Steiner I, Berger JR (2012) Update on progressive multifocal leukoencephalopathy. Curr Neurol Neurosci Rep 12(6):680-686. https://doi.org/10.1007/ s11910-012-0313-4

Subbiah P, Mouton P, Fedor H, McArthur JC, Glass JD (1996) Stereological analysis of cerebral atrophy in human immunodeficiency virus-associated dementia. J Neuropathol Exp Neurol 55(10):1032-1037

Taba P, Schmutzhard E, Forsberg P, Lutsar I, Ljostad U, Mygland A, Levchenko I, Strle F, Steiner I (2017) EAN consensus review on prevention, diagnosis and management of tick-borne encephalitis. Eur J Neurol 24(10):1214-e1261. https://doi.org/10.1111/ ene. 13356
Tan CS, Koralnik IJ (2010) Progressive multifocal leukoencephalopathy and other disorders caused by JC virus: clinical features and pathogenesis. Lancet Neurol 9(4):425-437. https://doi.org/10.1016/ s1474-4422(10)70040-5

Tardieu M (1999) HIV-1-related central nervous system diseases. Curr Opin Neurol 4:377-81

Tenhula WN, Xu SZ, Madigan MC, Heller K, Freeman WR, Sadun AA (1992) Morphometric comparisons of optic nerve axon loss in acquired immunodeficiency syndrome. Am J Ophthalmol 113(1):14-20

Thellman NM, Triezenberg SJ (2017) Herpes simplex virus establishment, maintenance, and reactivation: in vitro modeling of latency. Pathogens (Basel, Switzerland) 6(3). https://doi.org/10.3390/pathogens6030028

Thompson PM, Jahanshad N (2015) Novel neuroimaging methods to understand how HIV affects the brain. Curr HIV/AIDS Rep 12(2):289-298. https://doi. org/10.1007/s11904-015-0268-6

Tselis AC (2014) Cytomegalovirus infections of the adult human nervous system. Handb Clin Neurol 123:307-318. https://doi.org/10.1016/ b978-0-444-53488-0.00014-6

Uzasci L, Nath A, Cotter R (2013) Oxidative stress and the HIV-infected brain proteome. J Neuroimmune Pharmacol 8(5):1167-1180. https://doi.org/10.1007/ s11481-013-9444-X

Vago L, Bonetto S, Nebuloni M, Duca P, Carsana L, Zerbi P, D'Arminio-Monforte A (2002) Pathological findings in the central nervous system of AIDS patients on assumed antiretroviral therapeutic regimens: retrospective study of 1597 autopsies. AIDS (London, England) 16(14):1925-1928

Vartak-Sharma N, Nooka S, Ghorpade A (2017) Astrocyte elevated gene-1 (AEG-1) and the A(E)Ging HIV/ AIDS-HAND. Prog Neurobiol 157:133-157. https:// doi.org/10.1016/j.pneurobio.2016.03.006

Vera JH, Ridha B, Gilleece Y, Amlani A, Thorburn P, Dizdarevic S (2017) PET brain imaging in HIVassociated neurocognitive disorders (HAND) in the era of combination antiretroviral therapy. Eur $\mathrm{J}$ Nucl Med Mol Imaging 44(5):895-902. https://doi. org/10.1007/s00259-016-3602-3

Verma R (2012) MRI features of Japanese encephalitis. BMJ Case Rep 2012:bcr0320126088. https://doi. org/10.1136/bcr.03.2012.6088

von Stulpnagel C, Winkler P, Koch J, Zeches-Kansy C, Schottler-Glas A, Wolf G, Niller HH, Staudt M, Kluger G, Rostasy K (2016) MRI-imaging and clinical findings of eleven children with tick-borne encephalitis and review of the literature. Eur J Paediatr Neurol 20(1):45-52. https://doi.org/10.1016/j. ejpn.2015.10.008

Wattjes MP, Richert ND, Killestein J, de Vos M, Sanchez E, Snaebjornsson P, Cadavid D, Barkhof F (2013) The chameleon of neuroinflammation: magnetic resonance imaging characteristics of natalizumab-associated progressive multifocal leukoencephalopathy. Mult Scler (Houndmills, 
Basingstoke, England) 19(14):1826-1840. https:// doi.org/10.1177/1352458513510224

Weis S, Haug H (1989) Capillaries in the human cerebral cortex: a quantitative electronmicroscopical study. Acta Stereologica 8:139-144

Weis S, Haug H, Budka H (1993a) Astroglial changes in the cerebral cortex of AIDS brains: a morphometric and immunohistochemical investigation. Neuropathol Appl Neurobiol 19(4):329-335

Weis S, Haug H, Budka H (1993b) Neuronal damage in the cerebral cortex of AIDS brains: a morphometric study. Acta Neuropathol 85(2):185-189

Weis S, Llenos IC, Büttner A, Rebhan A, Soreth D, Mehraein P (1993c) Macroscopic morphometry of human brains in neurodegeneration. Acta Stereologica 12:299-304

Weis S, Neuhaus B, Mehraein P (1994) Activation of microglia in HIV-1 infected brains is not dependent on the presence of HIV-1 antigens. Neuroreport 5(12):1514-1516

Weis S, Haug H, Budka H (1996) Vascular changes in the cerebral cortex in HIV-1 infection: I. A morphometric investigation by light and electron microscopy. Clin Neuropathol 15(6):361-366

Weller SK, Coen DM (2012) Herpes simplex viruses: mechanisms of DNA replication. Cold Spring Harb Perspect Biol 4(9):a013011. https://doi.org/10.1101/ cshperspect.a013011

White MK, Khalili K (2011) Pathogenesis of progressive multifocal leukoencephalopathy-revisited. J Infect Dis 203(5):578-586. https://doi.org/10.1093/infdis/ jiq097

White MK, Sariyer IK, Gordon J, Delbue S, Pietropaolo V, Berger JR, Khalili K (2016) Diagnostic assays for polyomavirus JC and progressive multifocal leukoencephalopathy. Rev Med Virol 26(2):102-114. https:// doi.org/10.1002/rmv.1866

Wiley CA, Masliah E, Morey M, Lemere C, DeTeresa R, Grafe M, Hansen L, Terry R (1991) Neocortical damage during HIV infection. Ann Neurol 29(6):651-657. https://doi.org/10.1002/ana.410290613

Williams KC, Hickey WF (2002) Central nervous system damage, monocytes and macrophages, and neurological disorders in AIDS. Annu Rev Neurosci 25:537-562. https://doi.org/10.1146/annurev. neuro.25.112701.142822

Wilson AC, Mohr I (2012) A cultured affair: HSV latency and reactivation in neurons. Trends Microbiol 20(12):604-611. https://doi.org/10.1016/j. tim.2012.08.005

Wohlschlaeger J, Wenger E, Mehraein P, Weis S (2009) White matter changes in HIV-1 infected brains: a combined gross anatomical and ultrastructural morphometric investigation of the corpus callosum. Clin Neurol Neurosurg 111(5):422-429. Epub 2009 Jan 2029

Zambito Marsala S, Pistacchi M, Gioulis M, Mel R, Marchini C, Francavilla E (2014) Neurological complications of tick borne encephalitis: the experience of 89 patients studied and literature review. Neurol Sci 35(1):15-21. https://doi.org/10.1007/ s10072-013-1565-8

Zayyad Z, Spudich S (2015) Neuropathogenesis of HIV: from initial neuroinvasion to HIV-associated neurocognitive disorder (HAND). Curr HIV/ AIDS Rep 12(1):16-24. https://doi.org/10.1007/ s11904-014-0255-3 